\title{
HOW SHE SEES IT: CATALOGUING AND REHOUSING THE ARLEEN SCHLOSS SUPER 8MM FILM COLLECTION AT ANTHOLOGY FILM ARCHIVES
}

\author{
by \\ Traci Mark
}

Bachelor of Arts, York University, Toronto, Ontario, 2014

\author{
A thesis \\ presented to Ryerson University \\ in partial fulfillment of the \\ requirements for the degree of \\ Master of Arts \\ in the program of
}

Film and Photography Preservation and Collections Management

Toronto, Ontario, Canada, 2016

New York City, New York, United States, 2016

(C) Traci Mark 2016 


\section{Author's Declaration for Electronic Submission of Thesis}

I hereby declare that I am the sole author of this thesis. This is a true copy of the thesis, including any required final revisions, as accepted by my examiners.

I authorize Ryerson University to lend this thesis to other institutions or individuals for the purpose of scholarly research.

I further authorize Ryerson University to reproduce this thesis by photocopying or by other means, in total or in part, at the request of other institutions or individuals for the purpose of scholarly research.

I understand that my thesis may be electronically available to the public. 


\section{Abstract}

How She Sees It: Cataloguing and Rehousing the Arleen Schloss Super 8mm Film Collection at Anthology Film Archives

Master of Arts, 2016

Traci Mark

Film and Photography Preservation and Collections Management

Ryerson University

This thesis is an applied cataloguing project wherein 180 Super $8 \mathrm{~mm}$ films by multidisciplinary artist Arleen Schloss were catalogued at Anthology Film Archives from January-June 2016. Schloss is known mainly for her performance work within the Downtown New York art scene in the late 1970s/1980s, and for founding A's, a performance and art venue available for artists to show and experiment with their work. The objective of this thesis project was to catalogue Schloss's Super 8mm film collection at Anthology, while also conducting research on her artistic practice during the period she was most actively making films. There are two chapters; the first explores Schloss's background as an artist and gives context for the Downtown New York art scene and her place within it. The second chapter is a case study that details the cataloguing process of Schloss's Super 8mm films, and it also provides preservation recommendations for future use. 


\section{$\underline{\text { Acknowledgements }}$}

First and foremost, I would like to thank Dr. Izabella Pruska-Oldenhof for being a patient and attentive advisor through this process. This thesis would not have been possible without your guidance. Thank you to Dr. Tess Takahashi for always being so supportive of me throughout the years. I can only hope to inspire someone as you have inspired me. I consider myself lucky to have you as my second reader. Thank you to John Klacsmann and the staff at Anthology Film Archives for being so welcoming throughout the six months I was cataloguing the collection there. Thank you to everyone in the School of Image Arts department and the F+PPCM program. Thank you to Sur, Stuart and Gloria, for being so kind and always taking the time to answer any questions I had. And thank you to Arleen. You're a vision. Your work is authentic and important and I am honoured to say I worked with your collection of films. And a special thank you to my family and friends who have always been the most supportive, even during the hard moments. You are the ones who got me through. 


\section{Table of Contents}

List of Figures vii

List of Appendices viii

Introduction $\quad 1$

Chapter 1: Literature Review $\quad 5$

1.1 Arleen Schloss $\quad 6$

1.2 The Downtown New York Art Scene $\quad 10$

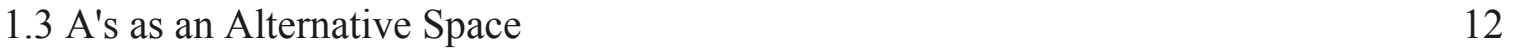

1.4 A Brief History of Super 8mm Film 14

1.5 Experimental Uses of Super 8mm Film 15

1.6 Schloss's Use of Super 8mm Film 17

Chapter 2: Case Study: The Arleen Schloss Super 8mm Film Collection 19

2.1 Donation Process 19

$\begin{array}{ll}2.2 \text { Methods } & 20\end{array}$

2.2.1 Text-Based Research 20

2.2.2 On-Site Research: Physical Description $\quad 21$

2.2.3 On-Site Research: Cataloguing 26

2.2.3i Naming Process 29

$\begin{array}{ll}\text { 2.2.3ii Language } & 30\end{array}$

2.2.4 Compilation Reels $\quad 30$

$\begin{array}{ll}2.3 \text { Sound } & 34\end{array}$

2.4 Ethics $\quad 35$ 


\section{$\underline{\text { List of Figures }}$}

Figure 1.1: Box of Arleen Schloss's Super 8mm film that were catalogued and donated to Anthology Film Archives.

Figure 1.2: Different angle of the same box shown in Figure 1.1.

Figure 2.1: Examples of what the films looked like before they were catalogued in their original containers.

Figure 2.2: The back of the boxes pictured in Figure 2.1

Figure 2.3: Kodak label on the side of the boxes with numbers imprinted into them.

Figure 2.4: A different angle showing the same Kodak label in Figure 2.3.

Figure 2.5: The corresponding cataloguing record to this film is shown in Figure 2.6.

Figure 2.6: An example of the information included in a cataloguing record; the corresponding film is shown in Figure 2.5.

Figure 2.7: The front three films with limited, unclear or indecipherable metadata on the outside of the container that would be considered "[Untitled]".

Figure 2.8: The back of a film with limited, unclear or indecipherable metadata on the outside of the container that would be considered "[Untitled]".

Figure 2.9: A film where the metadata on the container was clear and incorporated into the title.

Figure 2.10: An example of a compilation reel with 14 films in total.

Figure 2.11: A film that was rehoused on its own $150 \mathrm{ft}$. reel because the information on the reel is linked to an important event or performance. 


\section{$\underline{\text { List of Appendices }}$}

Appendix A: An Interview with John Klacsmann

Appendix B: Arleen Schloss's Curriculum Vitae

Appendix C: A's Posters

Appendix D: Films Catalogued Films and General Information 


\section{Introduction}

Arleen Schloss is often overlooked in the history of the vibrant Downtown New York City art scene of the mid- to late 1970s and 1980s. Her art practice spans across several media (e.g., painting, film, video, electronic arts) and disciplines (e.g., performance, poetry, music, visual arts). She is based in New York City; however, she has performed and showcased her work at many festivals, galleries, and arts spaces in Asia, Europe, and elsewhere in North America.

Schloss's artistic practice is characterized by process-oriented work and reflects the ethos that the final product is the least interesting part of the process. This concept is central to the part of Schloss's film collection that I will be discussing in this thesis. The collection includes over 300 reels of both finished and unfinished Super $8 \mathrm{~mm}$ films, contained in three cardboard boxes, that were donated to Anthology Film Archives in early 2015. My project at Anthology included cataloguing, inspecting, and rehousing the entire Arleen Schloss collection. However, this thesis specifically focuses on only one of the three boxes from the collection, which contained unfinished works. These films ranged from 10 to $50 \mathrm{ft}$. in length, they were both camera and cut original colour reversal prints (Kodachrome or Ektachrome colour reversal stock), and they were all still in their original Kodak boxes. In many cases, the actual year of production of these films was unclear, due to the limited metadata on the original film boxes. However, based on the manufacturing date codes on these films, these films date roughly from 1979 to 1987 . Most of these films have never been seen before and contain Schloss's documentations of daily life, performances at A's, people Schloss encountered in the city, and her travels abroad. Some of the films have been viewed by Schloss and screened at A's; others have not, and show no signs of handling or projector use. It must be emphasized that these films were not projected during the 
process of cataloguing; the images were only seen through a loupe and were therefore never seen in motion, only still. They were interpreted using a combination of the emulsion images when they were inspected with a loupe, Schloss's handwritten notes, and any information on the Kodak film boxes that came with each film. In this thesis, I focus my discussion on 180 unfinished Super 8mm films (Figures 1.1 and 1.2).

This thesis consists of two main chapters and four substantial appendices, one of which includes the outcomes of the project part of this thesis: the detailed catalogue entries for each of the 180 films. The first chapter includes a literature review, giving context and background information on Schloss's general artistic practice and A's, the Downtown New York art scene and Schloss's place within it. It also contains a brief history of Super $8 \mathrm{~mm}$ that leads to a discussion of how Schloss has used this format in her own film practice. The second chapter is the case study of the Arleen Schloss Super $8 \mathrm{~mm}$ Film Collection that provides practical information on the donation of this collection to Anthology Film Archives, the cataloguing methods that were used, and ethical considerations that arose during this process. Recommendations for the future use of this collection are reviewed in this chapter, and followed by a brief conclusion. The conclusion is proceeded by the first appendix (Appendix A), an interview I conduced with John Klacsmann, the chief film archivist at Anthology Film Archives, who was present for and instrumental in the initial donation of Schloss's films. The second and third appendices contain reproduced documents from Schloss's artist file at the Museum of Modern Art (MoMA): a copy of her curriculum vitae and reproductions of A's posters from the time period covered in this thesis (Appendix B and Appendix C, respectively). The last appendix (Appendix D) includes the outcome of the practical component of this thesis: a list of 180 catalogued Super $8 \mathrm{~mm}$ film titles, 
as well as the accession number and basic technical information about each film, including gauge, length, stock polarity, and element.

Lastly, it should be stated that the purpose of this thesis is twofold: first, it is intended to highlight the significance of the Super $8 \mathrm{~mm}$ films made by Arleen Schloss in the broader historical context of the downtown New York art scene in the late 1970s and 1980s; and, second, it is also meant to serve as a point of reference for similar collections and projects in the future, with the case study providing recommendations and the rationale for how to catalogue a large personal film archive. By cataloguing all these films, I aimed to provide access to Schloss's film work as a collection, which can be used as a research tool for future scholars. I hope that this thesis will begin a larger discourse about the art and activities of this significant but overlooked artist, as well as her role in this fruitful period in the history of New York City's art scene. 


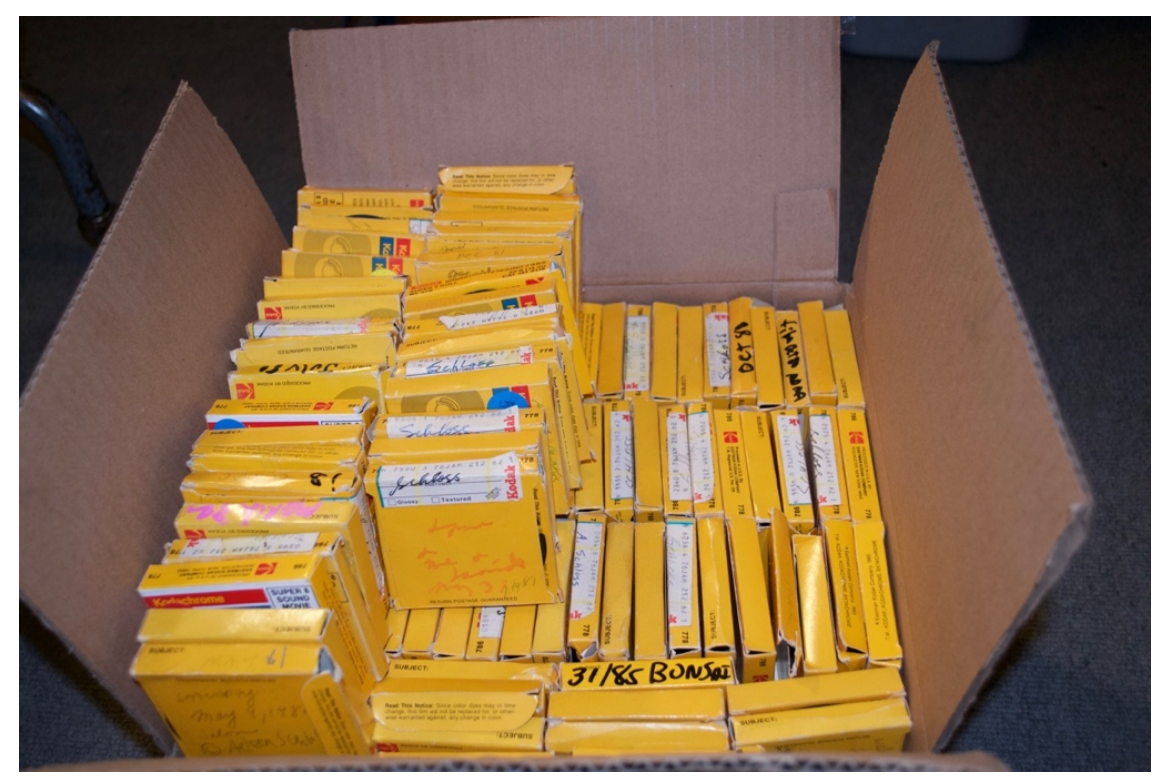

Figure 1.1

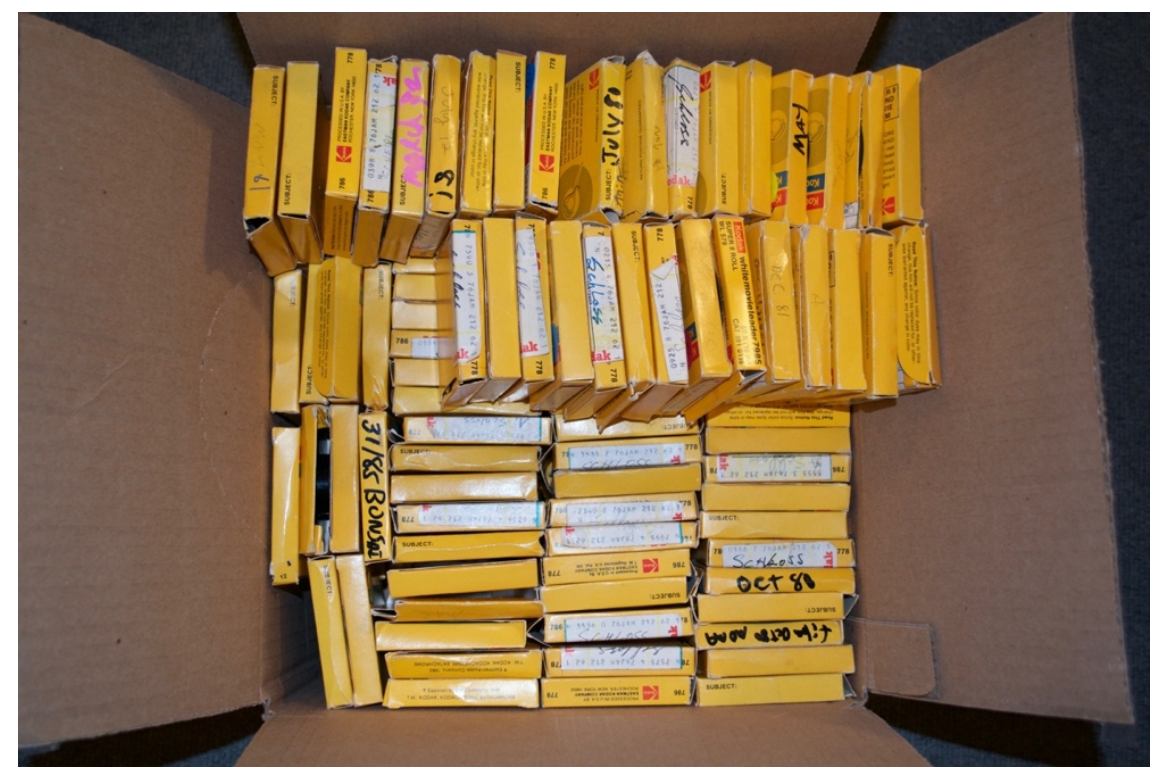

Figure 1.2 


\section{Chapter 1: Literature Review}

A wide variety of sources were consulted in order to understand Arleen Schloss's general artistic practice and her significance within the Downtown New York art scene in the late 1970s and throughout the 1980s (the period when she was most actively shooting film).

The first part of this literature review focuses on the artistic practice of Schloss and on A's. Most sources focus solely on Schloss as a performance artist and as the founder of A's none of them mention her film work. Sources that were consulted in this research consist of primary documents (written material from the period when she was most active as a filmmaker) from Schloss's MoMA artist file, the Franklin Furnace artist file, and online sources. The second part of this literature review focuses on the Downtown New York art scene and the larger historical context of the period, during which Schloss created A's and made her films. The last part of this literature review will include research on experimental and traditional uses of Super $8 \mathrm{~mm}$ film. Finally, I explain how Schloss's work embodies methods of both traditional and experimental Super 8mm filmmaking, and conclude by considering her work within the context of a recent exhibition of films by artist Ana Mendieta.

Learning about Schloss, her artistic practice, and A's also involved watching the digitized versions of her moving image work at Fales Library \& Special Collections at New York University (NYU). These viewings were supplemented by conversations with Schloss herself; with her fellow multidisciplinary artist and friend Sur Rodney Sur; with documentary filmmaker and her friend Stuart Ginsberg, who made the documentary Wednesdays at $A^{\prime} S(2006)^{1}$; and with Schloss's mother Gloria Schloss. Without these resources and people, the connections between the literature and her art practice would not have been particularly clear. The conversations I had

\footnotetext{
1 "Wednesdays at A's Teaser," YouTube video, 07:55, posted by Stuart Ginsberg, April 19, 2010 , https://www.youtube.com/watch?v=FcVs-3QHgjE.
} 
with these people provided me with a unique insight into Schloss as a multidisciplinary artist and filmmaker, as well as a better grasp of her work. This allowed me to work through the limitations of my research (namely, the small number of published sources on Schloss's work). Together with the literature and my personal experience cataloguing the collection of Schloss's Super 8mm films, these conversations form the basis for much of the information I provide in this thesis.

\subsection{Arleen Schloss}

Schloss was born in Brooklyn, New York in 1943 and is the daughter of two artists and former gallery owners. She began her career in painting and attended the prestigious Parsons School of Design in New York studying illustration, and taught for eight years at an elementary school in the Lower East Side. She began hosting a performance art workshop, which evolved into a weekly gig held at her Lower East Side loft. This space became an art venue where the public was invited to watch presentations, including performances and moving image pieces. The space also displayed visual art works for a small fee. This space was called A's and opened in 1979.

Schloss's influence on the New York art scene manifested through her founding and involvement with A's, which grew to become an interdisciplinary space and convergence point for artists to exhibit and perform their work. The space featured work and performances from many notable artists, including Glenn Branca, Steve Buscemi, Eric Bagosion, Phoebe Legere, Jean Michel-Basquiat's band Gray, Kim Gordon, Thurston Moore, and Ai Weiwei. All of these prominent figures have their own distinct art practices that bridge several disciplines and encompass music, film, performance, painting, and experimental work in electronic media. A's embodied the zeitgeist that developed during this period in New York City and was a space 
where these artists could openly explore their interdisciplinary interests and experiment with new art forms. Schloss's importance during this time is evident not only through her own versatility as an artist but also through her ability to bring other important artists together.

In the New Museum's publication Bowery Artist Tribute Vol. 2, Schloss and other artists who worked in the Lower East Side are featured, with many of them speaking about the beginning of their careers. ${ }^{2}$ Schloss talks about how A's began as a performance workshop for friends that became increasingly popular and inspired her to open her loft at 330 Broome Street (conveniently situated between two popular artist Meccas, The Lower East Side and SoHo) as a weekly open space for artists working in any discipline to gather, create, and share ideas. ${ }^{3}$ Schloss also did performances at A's that were later presented at several renowned institutions in New York, including MoMA, The Storefront for Arts and Architecture, and The Kitchen. ${ }^{4}$ In her performance pieces, Schloss often explored the alphabet, which would usually be written or chanted rhythmically in succession, integrating musical undertones into the piece. ${ }^{5}$ This was often the focus of commentary by critics in their reviews of her work. ${ }^{6}$ After one of her performances, Dave Erickson writing for The University of Rochester's monthly publication Currents noted that "she is not so much interested in product (an "art object") as in process." ${ }^{7}$ In 2006, the New Museum showcased a program of her film and video work in the exhibition Come Closer: Art Around the Bowery, 1969-1989. This museum is based in the Lower East Side and the exhibition featured artists who produced work in this area. The museum uploaded a video to

\footnotetext{
${ }^{2}$ Ethan Swan, "Arleen Schloss," in Bowery Artist Tribute Vol. 2., edited by Ethan Swan (New York: New Museum, 2010), 15-16.

3 Ibid.

${ }^{4}$ Ibid.

${ }^{5}$ Robert Palmer, "Music (?): Kitchen Sink," New York Times, October 13, 1977.

${ }^{6}$ Wendy Perron, "Dumb Art: Beautiful, But Not Too Bright," The Village Voice, January 2, 1978.

${ }^{7}$ Dave Erickson, "An Exhibit with Real Snap- By Any Stretch of Imagination," The University of Rochester Current, 1975.
} 
YouTube in 2012 with Schloss being interviewed about her work. In the video, Schloss states that she "was experimenting with Super 8 film and language [...] therefore there was no border to art forms. I was doing and accepting experimental art forms." ${ }^{8}$ Experimentation and processoriented work are the recurring themes that critics writing about her work often note, as did Schloss herself.

Schloss often performed her own work at A's, using this as an opportunity to experiment with her moving image work and performance pieces. Schloss's performances were not easy to define; critics and audiences have commonly used terms such as conceptual, minimal, pop art, or (the obvious) performance art. Certain critics even went as far as to call it "dumb art" but would immediately follow this statement by clarifying:

It's not to be confused with numbness, or silence or primitivism, but it shares elements with all three. Dumbness is an insistence on not knowing, a goodnatured rebellion against the overwhelming number of facts and experiences that assail us each day. It's akin to the political and aesthetic rebellion of the ' $60 \mathrm{~s}$ but not so earnest, not so bitter. It acknowledges the decorativeness, not to say shallowness, of the sensibility behind much of today's art. And it takes the irony in this art a step further. ${ }^{9}$

In this passage, Wendy Perron from The Village Voice astutely points out that only calling Schloss's work "dumb" would be too simple and incredibly inaccurate. After listening to Schloss rhythmically chanting words and letters, one begins to (over)hear other words, hence new meanings emerge that the mind subconsciously constructs. Language and meaning are not necessarily correlated in Schloss's performance art, and actions do not embody the meaning of the words being spoken on stage. In this way, the apparent simplicity of her performances was her strongest ammunition for "a good-natured rebellion," which compelled the audience to

\footnotetext{
8 "Interview with Arleen Schloss," YouTube video, 02:44, posted by New Museum, December 21, 2012, https://www.youtube.com/watch?v=DXHMIUJv6N4.

${ }^{9}$ Perron.
} 
question their own interpretations of the words spoken by Schloss as they were hearing them. Schloss provided the audience with a sensory experience by engaging them with sound and movement, allowing the audience to question modes of thinking and being that have been repressed by logic.

Schloss is mainly known as a performance artist, but her work is beyond a single definition and surpasses the boundaries of traditional art practices. It was common for Schloss to mix media or feature moving image pieces, including Super $8 \mathrm{~mm}$ films, in her live performances. Super $8 \mathrm{~mm}$ and $16 \mathrm{~mm}$ were her chosen film formats, and her films focus on the people and places she encountered in her everyday life and during her travels. Many of her films also include documentation of performances that happened at A's. These films served as a visual memory for Schloss and in viewing her work we are able to see life through her eyes.

How She Sees It by Her (1981) is one of the best-known pieces in Schloss's large body of film work, and also the most personal. Part diary, part quasi-documentary, the film features Schloss as she hurriedly narrates details of the failure of her first marriage, while street scenes of New York City quickly play on screen:

She's at a funny place in her mind at this moment-bewildered and angry she thinks about how she has taken care of herself at different times in her life. She's vulnerable yet strong. Her vulnerability is her strength. She likes to try different things. She was smart to save some money while she was making money. And her savings have just run out. ${ }^{10}$

The viewer is immediately transplanted into Schloss's personal life and intimate thoughts. Seeing life through Schloss's eyes is a common theme throughout her entire body of film work. How She Sees it by Her began as an audiotape recording of a poem of the same title; it then turned into a performance piece with several variations, and eventually became a film, shot on Super $8 \mathrm{~mm}$.

\footnotetext{
${ }^{10}$ How She Sees It by Her, directed by Arleen Schloss (Arleen Schloss, 1981), Super 8mm film with sound added, from Anthology Film Archives, accessed February 28, 2016.
} 
Schloss kept on adding new parts to this film whenever she thought it would enhance the film. The latest and final addition was footage of the World Trade Center towers when they collapsed during the 9/11 attack.

Schloss stopped regularly hosting A's weekly nights and other art events around the city in the early 1980s. In following years, A's events were still being held but sporadically; the last official event was in 1987. Schloss spent the mid-1980s travelling around the world, which also included a European tour with Glenn Branca and his band. In the 1990s, Schloss made her loft available as an affordable space for artists to stay while visiting New York City. A's Wave and was meant to continue the tradition of bringing artists together to facilitate creative exchanges. In the early 1990s, Schloss was employed by Nickelodeon, an American television network aimed at children and adolescents. She worked with children and created video content for the network. Between the early to mid-1990s, Schloss also founded the Techno Chicks, a group of women who incorporated technology into their artistic practices and would frequently meet to exchange ideas. In the late 1990s, Schloss was diagnosed with Multiple Sclerosis, which has impeded her ability to produce more work.

Schloss's video work and personal papers are held at Fales Library \& Special Collections at NYU, and all of her film materials are at Anthology Film Archives.

\subsection{The Downtown New York Art Scene}

It was one of those "Is it Art?" moments. ${ }^{11}$

The Downtown New York art scene in the 1970s and 1980s comprised many movements and scenes that existed in one geographical location during a particular time. There is no one

\footnotetext{
${ }^{11}$ Marvin J. Taylor, ed., The Downtown Book (Princeton: Princeton University Press, 2006), 1.
} 
specific event, artwork, or aesthetic that can define it as a unified movement. Chaos was one of the most important qualities of this art scene. The chaos of this scene was synonymous with a cultural revolution that formed during a time when Downtown New York City served as an artist haven, due to cheap and affordable rentals and a unified attitude toward the many forms that art could assume. Experimentation and cross pollination of disciplines was commonplace and encouraged. Traditional art practices and gallery spaces were questioned, even critiqued and undermined in the process, forcing artists to create their own alternative spaces to develop and showcase their work.

What is so fascinating about this particular time in the Downtown art scene- - that is, the years between 1974-1984 - is that it not only bore witness to, but also spawned the transition from modernism to postmodernism. One crucial aspect of this transition is manifested in artists' desire to break out of the framework of the established art world. Another is in the spectator's heightened role- the notion that engaged audiences should participate in a work's completion. ${ }^{12}$

The complex political landscape at the time was informed by a myriad of social issues, including the Vietnam War, racism, sexism, homophobia, poverty, and many others. The conservative Uptown art scene was displayed in more traditional, commercial, and institutional exhibitions, all from which the more progressive and inclusive Downtown art scene wanted to separate. This separation resulted in alternative art spaces like A's.

Neighborhoods that fostered this flow of creativity included the Lower East Side, the East Village, SoHo, and Tribeca. Areas below $14^{\text {th }}$ Street offered opportunities to artists as they were able to afford to pay the rent for subpar but tolerable living conditions, whilst also creating artwork. Many immigrants of various nationalities came to these areas in search of a better life. The result of this was an influx of art and non-conformist cultures, which brought relevance and allure to the parts of New York City that had been long overlooked and cast off as unimportant.

\footnotetext{
${ }^{12}$ Ibid., 11.
} 
It is no small irony that the act of inhabiting these spaces and establishing artistic communities within them generated an economic boom that made SoHo and the neighboring area of Tribeca no longer affordable for most artists. ${ }^{13}$

The cultural boom that occurred in the Downtown area attracted residents from other parts of the city to move, causing gradual increases in rent and costs for property.

Much has been written on the Downtown New York art scene, including books that cover the period when Schloss was active with A's. The Downtown Book: The New York Art Scene 1974-1984 ${ }^{14}$, Downtown Film \& TV Culture 1975-2001 ${ }^{15}$, and Alternative Art New York: 1965 $1985^{16}$ all provide detailed accounts of the history of the Downtown New York art scene, with testimonies from artists who were prolific during this time and from scholars who focus on this period.

\subsection{A's as an Alternative Space}

On October 29, 1979, Schloss opened her Lower East Side loft to the public for the first time for a weekly night of artist creations and exhibitions. This came as a response to the growing need for alternative spaces where artists could work and create. A's as an artist venue focused on process-oriented work and presented artists with a space to present their work to the public and to experiment. Any artistic discipline was welcome, and artists of any gender, sexual orientation, or ethnic background could exhibit. This was during a time when typical art spaces were not always inclusive of women or people with diverse ethnic or cultural backgrounds. The tedious administrative formalities and paperwork that came with showing one's work at

\footnotetext{
${ }^{13}$ Lauren Rosati and Mary Anne Staniszewski, eds. Alternative Histories New York Art Spaces 1960 to 2010 (Cambridge: The MIT Press, 2012), 18.

${ }^{14}$ See Taylor, 9-174.

${ }^{15}$ See Joan Hawkins, ed., Downtown Film \& TV Culture 1975-2001 (Chicago: The University of Chicago Press, 2015), 21-28.

${ }^{16}$ See Julie Ault, ed., Alternative Art New York: 1965-1985 (Minneapolis: University of Minnesota Press, 2002), 231-367.
} 
traditional galleries or museums was not required at A's. If it was a piece in progress, a regular work, or just an amorphous idea that still needed shaping, Schloss always said "yes" to showing it at A's. It was a safe environment where one could try something and fail, to see what worked and what did not.

In Stuart Ginsberg's extended trailer for the Wednesday's at A's documentary, artists such as Gracie Mansion, Joe Lewis, Phoebe Legere, and Eric Bagosian describe A's as a rite of passage in the performance art world and as an alternative to showing work in a gallery. They also comment on Schloss's progressive attitude in opening the space to any gender, sexual orientation, and ethnic background. ${ }^{17}$

Schloss often showed her own films at A's spontaneously and usually as gallery pieces projected on a wall where attendees could walk freely and explore the space. Other times, she would interact with a projection of her moving image work, while performing in front of it. (Some of these moving image works (the Super $8 \mathrm{~mm}$ films) were inspected in this thesis project. They contain the traces of these performances in projector burns and pulled perforations, due to projection problems.) There did not seem to be a particular pattern in her choices of the type of subject or content in the films she showed most often. A's lasted until the mid 1980s.

Alternative Histories: New York Art Spaces, 1960 to 2010 ${ }^{18}$, Captured: A Film/Video History of the Lower East Side ${ }^{19}$, and Alternative Art New York, 1965-1985 ${ }^{20}$ are the only three books on the Downtown New York art scene that actually mention Schloss's work. Captured

\footnotetext{
17 "Wednesdays at A's Teaser."

${ }^{18}$ See Rosati and Staniszewski, 188.

${ }^{19}$ See Clayton Patterson, "Arleen Schloss Interview," in Captured: A Film/Video History of the Lower East Side, ed. Paul Bartlett, Urania Mylonas, and Clayton Patterson (New York: Seven Stories Press, 2005), 193-206.

${ }^{20}$ See Ault, 231-367.
} 
contains an interview with Schloss and Alternative Histories has a section that focuses on A's and what it was.

\subsection{A Brief History of $8 \mathrm{~mm}$ and Super $8 \mathrm{~mm}$ Film}

Super $8 \mathrm{~mm}$ film rose to prominence in the mid-sixties as an improved alternative to the double $8 \mathrm{~mm}$ (also known as standard $8 \mathrm{~mm}$ or regular $8 \mathrm{~mm}$ ) format. Standard $8 \mathrm{~mm}$ was introduced to the market in 1932, but had not been as successful as initially expected in the commercial, industrial, or educational markets. ${ }^{21}$ The $16 \mathrm{~mm}$ film gauge was too costly for amateur filmmakers, and the $8 \mathrm{~mm}$ equipment provided fewer potential technical and financial issues than $16 \mathrm{~mm}$ or $35 \mathrm{~mm} .^{22}$ Compared to its predecessors, $8 \mathrm{~mm}$ is sometimes referred to as a reality-based medium. ${ }^{23}$ The images produced are relatively low-definition and suited to documenting reality rather than glamourous, fictional images. ${ }^{24}$ In Jonathan F. Gunter's Super 8 :

The Modest Medium he states that,

Super-8 film offered features which had not been available in any previous film format. To eliminate loading problems, super 8 film was packaged in cartridges, which went into the camera quickly and with no chance for error. The film was cut $8 \mathrm{~mm}$ wide, and was designed for a single pass. When the film was exposed, the cartridge was simply taken out of the camera and sent to the laboratory. ${ }^{25}$

Most Super 8mm cameras contain built-in light meters and an automatic exposure control, thereby producing adequately exposed images without users needing to learn how to operate a light meter. Compared to the double $8 \mathrm{~mm}$ film, the image area of Super $8 \mathrm{~mm}$ was 50 percent

\footnotetext{
${ }^{21}$ Alan Kattelle, Home Movies: A History of the American Industry, 1897-1979 (Nashua, NH: Transition Publishing, 2000), 204.

${ }^{22}$ Jonathan F. Gunter, Super 8: The Modest Medium (Paris, FR: UNESCO, 1976), 20.

${ }^{23}$ Ibid.

${ }^{24}$ Ibid.

${ }^{25}$ Ibid, 23.
} 
larger, owing to the reduction of the sprocket hole size. ${ }^{26}$ Stocks were sold in both colour and black-and-white reversal, with a choice of colour balanced for daylight shooting. ${ }^{27}$

By the end of 1966, Kodak itself had discontinued all but one standard $8 \mathrm{~mm}$ camera due to the Super 8mm's success on the market. Within two years of the introduction of the format, "the number of standard $8 \mathrm{~mm}$ camera models offered on the US market by all manufacturers dropped from a high of 117 in 1964 , to a mere 38 in the 1967 directories". ${ }^{28}$

\subsection{Experimental Uses of Super 8mm Film}

Artists and filmmakers such as Carolee Schneemann, Storm De Hirsch, Ken Jacobs, Stan Brakhage, Saul Levine, Marjorie Keller, Anne Charlotte Robertson, Chris Marker, Vivienne Dick, Gary Adelstein, Charlie Ahearn, Gordon Ball, and Stan King have all used Super 8mm in their artistic practice at some point. In MoMA's and San Francisco Cinematheque's accompanying catalogue to their Big As Life: An American History of $8 \mathrm{~mm}$ Films exhibition, Steve Anker states in the first chapter that,

For filmmakers who moved back and forth between $8 \mathrm{~mm}$ and $16 \mathrm{~mm}$, the smaller gauge's fragility and delicacy were used to reflect the most private physical and psychological spaces of everyday lives-in exhibition as well as production. ${ }^{29}$

This correlation between intimate moments and private thoughts conveyed through the Super $8 \mathrm{~mm}$ format is a common theme that appears in the work of many experimental filmmakers.

New interest in Super $8 \mathrm{~mm}$ is reemerging, not only among young filmmakers but also galleries and museums. Ana Mendieta: Experimental and Interactive Films was a recent

\footnotetext{
26 Ibid.

27 Ibid.

${ }^{28}$ Kattelle, 212.

${ }^{29}$ Steve Anker, Big As Life: An American History of $8 \mathrm{~mm}$ Films (San Francisco, CA: Museum of Modern Art and San Francisco Cinematheque, 1998), 6.
} 
exhibition held at Galerie Lelong in New York City from February 5, 2016-March 26, $2016 .{ }^{30}$ It featured several unknown films that were recently discovered in the artist's estate collection. ${ }^{31}$ Like Schloss, Mendieta was a multidisciplinary artist whose performance art work was well known. Mendieta was also a prolific filmmaker, who mainly worked in the Super $8 \mathrm{~mm}$ format and made over 100 films. The Ana Mendieta exhibition focused solely on her film work. Her films were presented in one, large, cuboid open space, which was painted black to emphasize the projected image. They were projected digitally, side by side, playing on a loop (without sound). Attendees were encouraged to freely navigate the space and go from one film to the next. The gallery space for Mendieta's exhibition presented the films in a similar manner to how Schloss would have shown her films at A's, i.e., as projection installations. The participatory nature of the exhibition space at Galerie Lelong facilitated a creative exchange between the gallery patrons and Mendieta's films. Viewing each film side by side allowed one to make observations that, otherwise, would have not been noticed if presented in a cinema playing a sequence, one after the other, in a multi-artist experimental program, or even in a solo artist film program. This approach also empowered gallery patrons to choose the order in which they, rather than the curator, would like to view each film and how long they would stay (i.e., how much of each film they would see), as sequencing and duration contribute to the interpretations of films.

Like Mendieta's films, if Schloss's films were to be screened in the future they would be presented digitally, since the films are camera originals and are the only copies that exist. Screening the films on the original format would open the possibility of unnecessary projection damage. Most likely, Schloss's Super 8 original films would be shown in a curated program at

\footnotetext{
${ }^{30}$ Ana Mendieta: Experimental and Interactive Films: February 5, 2016 - March 26, 2016," Galerie Lelong, accessed April 14, 2016, http://www.galerielelong.com/exhibition_pr/3377.

31 Ibid.
} 
Anthology Film Archives's Maya Deren Theatre. This form of film presentation would be less participatory than the setting created for Mendieta's films at Galerie Lelong, forcing the viewer to focus on one piece at a time and in a predetermined by the curator sequence of films. On the other hand, a cinema can properly present sound, which is something that galleries can rarely accommodate in the same way. Sound is one of the key features that separates Mendieta's and Schloss's films. Galerie Lelong's exhibition displayed silent films only. Both modes of presentation have positive and negative aspects. This begs the question: what influence can a space have on the experience and reception of film, and in what ways can the space enhance or diminish what is being shown on screen?

\subsection{Schloss's Use of Super 8 Film}

Schloss's primary use of Super 8mm film was for portraiture, which includes film selfportrait. Many artists have found it natural to focus in their films on themselves, their friends, lovers, and acquaintances. ${ }^{32}$ Schloss often filmed the people and places she encountered, and sometimes turned her camera on herself by focusing on a particular part of her body, such as her eyes or mouth. Schloss's extensive footage of the people who attended the weekly Wednesday A's event and other events that happened could also be viewed as portraiture, providing visual identity to this alternative space and its participants. The footage of her own performances can be seen as a form of self-portraiture, displaying one of her personas. Schloss also used Super 8mm in its most traditional sense, as described by Anker in Big as Life: "Most notably, film allowed individuals to make their own records, whether of important events in their lives or of playful home-spun fantasies." ${ }^{33}$ Super $8 \mathrm{~mm}$ provided Schloss with a format to create visual memories of

\footnotetext{
32 Anker, 4-15.

${ }^{33}$ Ibid, 4.
} 
her life. A Super $8 \mathrm{~mm}$ camera is portable and unobtrusive, easy to load, and does not require the preparation and technical training that other gauges needed, ${ }^{34}$ as many technical features (e.g., the built-in light meter, low-light capability, and manual and electric zoom) are already built into the camera. ${ }^{35}$ It is, therefore, easy to operate. This presents Super $8 \mathrm{~mm}$ as a gauge intended for production rather than distribution ${ }^{36}$; suited more for private presentations (among friends or family) rather than public presentations. In view of the fact that Schloss was shooting on reversal stock, which meant that there was only one print (the final camera original print), the intention was not likely to distribute this work, but to explore and experiment with the medium. These inherent qualities of Super 8mm were indeed very well aligned with Schloss's ethos of processoriented work.

${ }^{34}$ Gunter, 84.

${ }^{35}$ Ibid.

${ }^{36}$ Ibid. 


\section{Chapter 2: Case Study: The Arleen Schloss Super 8mm Film Collection}

This chapter explores the technical details of the film donation process, physical description, and cataloguing methods that were used while rehousing and cataloguing the Arleen Schloss Super $8 \mathrm{~mm}$ film collection. This section also outlines the ethical issues that arose while cataloguing and assigning titles to film works, and the implications on access these may have for this collection in the future. My interview with John Klacsmann (Appendix A) is the main source of information I provide in this chapter, on the complex process of assessing and cataloguing a large body of artist's film work with little background information available on the artist and even less on the films and their contents.

\subsection{Donation Process}

The Arleen Schloss film collection was donated to Anthology Film Archives in January 2015. Schloss also donated the rights to Anthology and signed an agreement to this fact. John Klacsmann, the chief film archivist at Anthology, was initially approached by Schloss's friend and fellow multidisciplinary artist Sur Rodney Sur regarding this donation. Sur explained that Schloss's video work and papers were already at Fales Library \& Special Collections at NYU, and that Anthology would be a suitable place for her film work. There were two good reasons backing this donation. First, the two archives would stimulate each other and give their collections physical proximity, encouraging greater possibilities for access and study opportunities in the future. Second, Anthology is equipped to care for film, with a humiditycontrolled vault and extensive experience handling large film collections.

Klacsmann had not heard of Schloss at the time he was approached by Sur; however, he had heard of the influence A's had on the Downtown New York art scene in the late 1970s and 
1980s. Most of Schloss's film work consists of documentation, and visual diary of her everyday life and performances at A's. A's had been a place where many artists performed and showcased their work while experimenting within multiple disciplines. Documentation of this time by a person (Schloss) who was active within the scene would likely be useful for researchers and scholars in the future. In addition, How She Sees It by Her (1981) was already in Anthology's collection before this donation. Klacsmann agreed to take all of Schloss's films into the collection, including all unfinished works and outtakes, which is uncommon for most moving image archives. Films that were completed, such as all the film titles in Schloss's New Museum Showcase $^{34}$, were indexed, catalogued and digitized first, in early 2015.

\subsection{Methods}

\subsubsection{Text-Based Research}

Research into the Downtown New York art scene began prior to the start of my residency at Anthology Film Archives. This was mainly to provide me with insight and context of the time period, but this research also proved to be a valuable resource later, during the cataloguing and rehousing process. Most of the Kodachrome and Ektachrome film boxes contained either handwritten notes or labels that Schloss had written herself. Researching the Downtown New York art scene during the 1970s and 1980s was useful in deciphering the writing on these boxes. Names of people and places were easier to identify and add confidently to the cataloguing records. Creating a complete record was a priority, as it affects future access to the collection.

\footnotetext{
34 "Arleen Schloss: An Evening of Super 8 Film and Hi8 Video," New Museum, accessed October 5, 2015. http://www.newmuseum.org/calendar/view/arleen-schloss-an-evening-of-super-8-film-and-hi8-video.
} 
Primary sources were consulted in this research. Texts on Schloss were obtained from Schloss's artist file at MoMA and included newspaper and magazine articles from the time, mostly reviews of her performances in the New York state area. MoMA also acquired The Franklin Furnace archive's artist's books, including their artist file on Schloss. These text-based sources were consulted to familiarize myself with the background of Schloss's artistic practice. However, speaking with Schloss in person, Sur Rodney Sur, Stuart Ginsberg, and Gloria Schloss proved to be the greatest source of information into Schloss's artistic practice and background as an artist.

\subsubsection{On-Site Research: Physical Description}

In this thesis project, I focused on one of the three cardboard boxes of Super $8 \mathrm{~mm}$ films, which comprise the Arleen Schloss film collection at Anthology. The collection consists of 180 Kodak Ektachrome and Kodachrome films, in their original film boxes from the film laboratory (Figure 2.1 and 2.2). In most instances, the boxes contain a $50 \mathrm{ft}$. black plastic reel with 10 to 50 ft. of film. In some cases, the film was either loosely placed in the box without any reel, or was in multiple pieces on the reel and required reinforcement with splicing tape to re-attach the

pieces. These boxes usually contained a circular sticker on the front with a number on it from the film lab, and a Kodak label on the side with a sequence of numbers and letters printed on it (Figure 2.3 and 2.4). Most often the film boxes contained handwritten notes made by Schloss around the time of their production (Figure 2.4).

Kodachrome was put on the market in 1935 by the Eastman Kodak Company (Super $8 \mathrm{~mm}$ Kodachrome cartages were launched in 1965). The unique and complex Kodachrome process involves colour dye that is added to essentially black-and-white film during the 


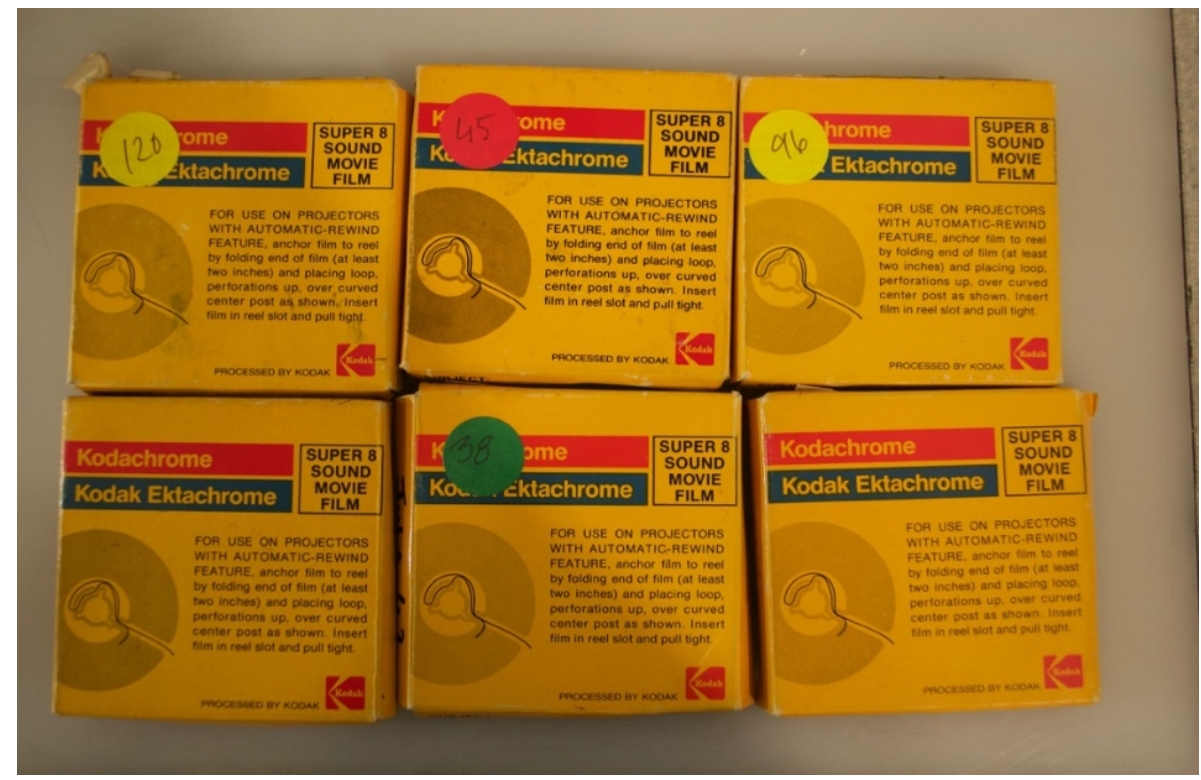

Figure 2.1

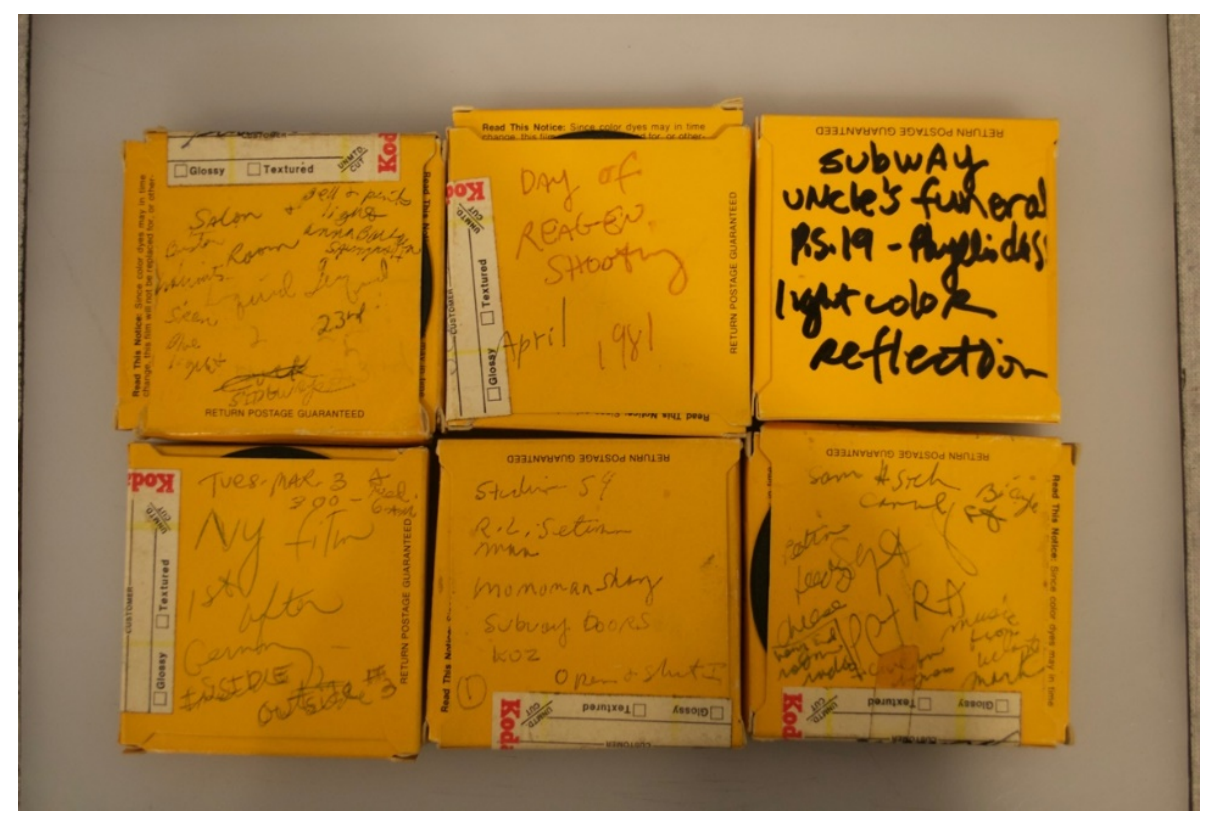

Figure 2.2 


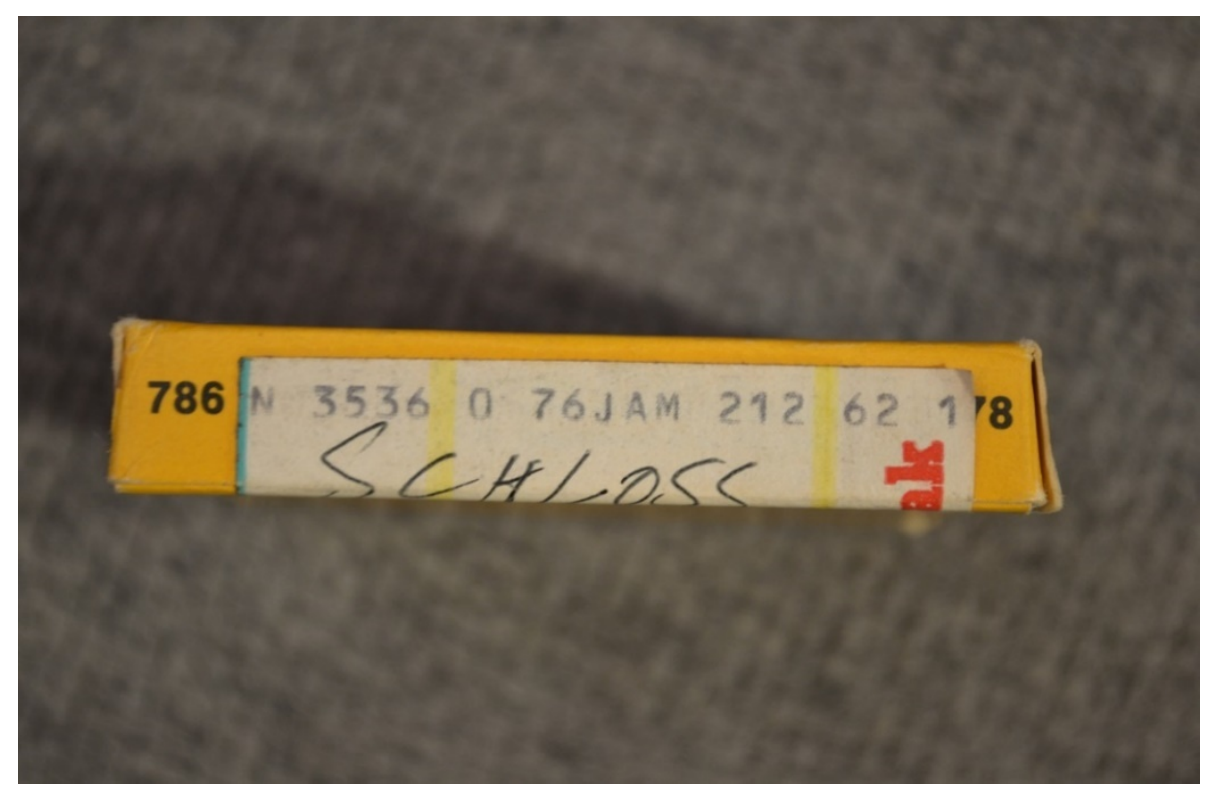

Figure 2.3

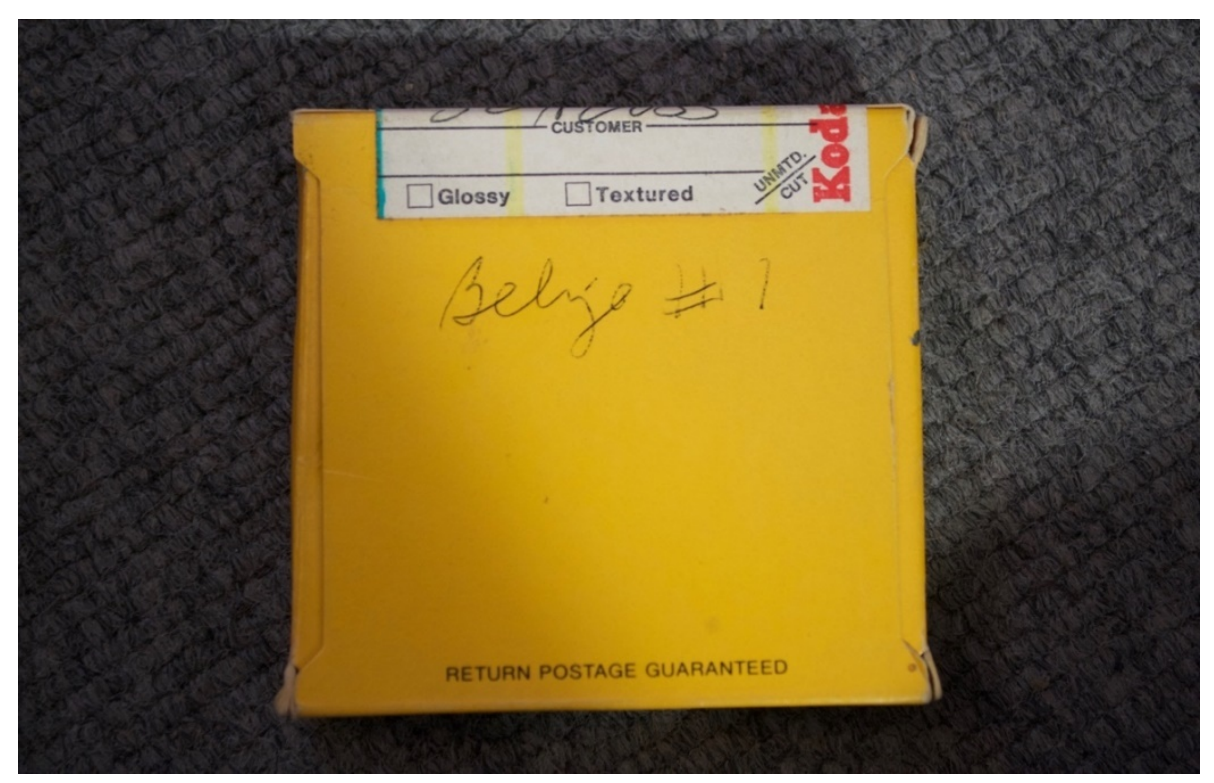

Figure 2.4 
development process, whereas other film stocks have dyes present in the emulsion. ${ }^{35}$ The revenues from Kodachrome equalled less than $1 \%$ of Kodak's gross profit. ${ }^{37}$ This lead to the discontinuation of Kodachrome stock in $2009^{38}$ However, due the complicated development process, the film's archival abilities have proven it to be a reliable stock. If stored properly, it is capable of lasting up to 100 years with no shifts in colour. ${ }^{39}$

Ektachrome was introduced in 1946 (Super 8mm film cartages were introduced in 1971). After 2009, Ektachrome was typically recommended as an alternative when Kodachrome was discontinued. ${ }^{40}$ Ektachrome colour reversal is known for its rich colours and sharp images. ${ }^{41}$ It was marketed as a stock that consumers could process themselves using the Kodak chemical kits, also introduced around the same time. This gave instant appeal to Ektachrome, as processing was easier and consumers to do it themselves, whereas Kodachrome had many additional steps that made it almost impossible to develop outside of the film lab. Ektachrome was also discontinued, not long after Kodachrome, in 2012.

In comparing Kodachrome and Ektachrome stocks during inspection and cataloguing, I noticed that the Kodachrome films had very little image fading, if any. Even though the collection has not been stored in ideal conditions until 2015, the colours in most of the Kodachrome films are still intact. The quality of the colour in the Ektachrome films varied more

\footnotetext{
${ }^{35}$ Claire Suddath, "A Brief History of Kodachrome," Time Magazine, accessed March 25, 2016, http://content.time.com/time/arts/article/0,8599,1906503,00.html.

${ }^{37}$ Ibid.

${ }^{38}$ Terrence Dick, "Koda-Crime! A Eulogy to Super 8 Kodachrome," This Magazine, November/December $2005,12$.

${ }^{39}$ Suddath.

${ }^{40}$ Chris Gampat, "Remembrance: Four Years Since the Death of Kodak Ektachrome," The Phoblographer, last modified March 1, 2016, accessed April 4, 2016, http://www.thephoblographer.com/2016/01/03/remembrance-fouryear-since-the-death-of-kodak-ektachrome/\#.V0RbRsfSdo4.

${ }^{41}$ Kodak Ekatchrome 100 Professional Film Technical Data/ Color Reversal Film (Rochester: Eastman Kodak Company, 2007), 2-5, accessed April 6, 2016, http://www.kodak.com/global/en/professional/support/techPubs/e27/e27.pdf.
} 
often. Certain films still contain vibrant hues, but many of them have turned magenta or purple in colour, indicating signs of dye fading. Certain films are in very good condition and appear as if they have never been projected. Other films are severely damaged from projector issues. Pulled perforations and horizontal scratching on the emulsion side of the film were the most common issues encountered.

\subsubsection{On-Site Research: Cataloguing}

After each film was carefully inspected, cataloguing records were created using CollectiveAccess, an open-source collection management and presentation software used by Anthology. Collective Access is known for being extremely customizable, and was originally designed for archives, museums, and special collections. ${ }^{42}$ Its versatility has proven to be an asset, as Anthology's catalogue employs atypical metadata standard that focuses specifically on information about the object itself, rather than content.

Figures 2.5 and 2.6 show an example of a Kodak film box and the corresponding cataloguing record information. The structure of the catalogue has continued to resemble what it was when Anthology began cataloguing films in the $1970 \mathrm{~s} .{ }^{43}$ Often, the vocabularies that are linked to the description of motion picture film are not accurate in describing the unique physical qualities that some experimental films can embody. This is why the portion of the catalogue that would be commonly used at other archives for description of the content, Anthology uses to

\footnotetext{
42 "About CollectiveAccess," CollectiveAccess, accessed April 6, 2016, http://www.collectiveaccess.org/about.

43 John Klacsmann, interview by Traci Mark, May 3, 2016, Anthology Film Archives, New York, NY.
} 
describe the physical condition of the work instead. Descriptive metadata, including the handwritten notes, on the outside of the film box is also included in this portion of the catalogue.

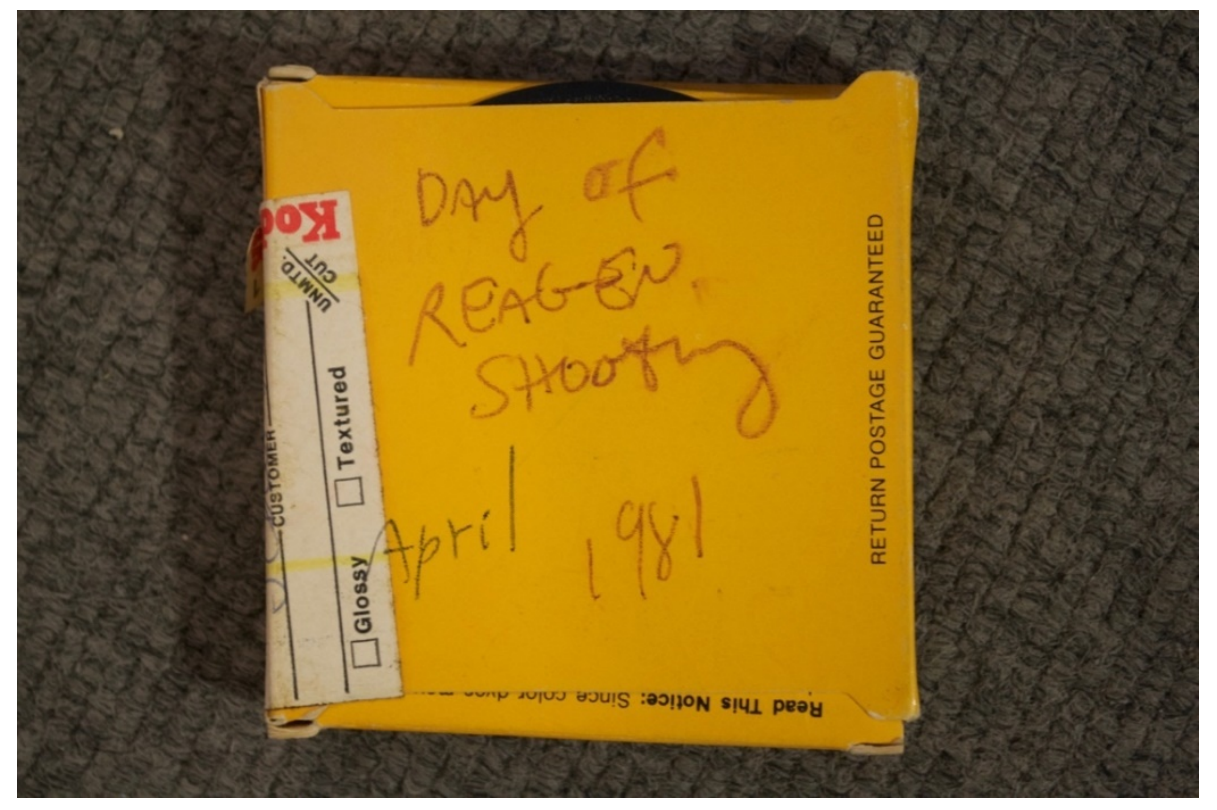

Figure 2.5 


\begin{tabular}{|c|c|c|c|}
\hline BASIC FILM INFOMATION & & \multirow[t]{10}{*}{ Condition Information: } & \multirow{10}{*}{$\begin{array}{l}\text { Originally on a black reel } \\
\text { inside a Kodak } \\
\text { Kodachrome/Ektachrome } \\
\text { Super } 8 \text { Sound Film box. "100" } \\
\text { is handwritten on a yellow } \\
\text { sticker on the front of the box. } \\
\text { "A" is written on one side of } \\
\text { the box, the other side } \\
\text { contains a Kodak label with "N } \\
0925876 \text { AM } 21261 \text { 1" } \\
\text { printed on it. "Schloss" is also } \\
\text { written on the label. "Day of } \\
\text { Reagan Shooting" and "April } \\
1981 \text { " is written on the back of } \\
\text { the box. }\end{array}$} \\
\hline Film Title & [Day of Reagan Shooting] & & \\
\hline Related Entities & Arleen Schloss & & \\
\hline Related Storage Location & $\begin{array}{l}\text { Anthology Film Archives Film } \\
\text { Vault }\end{array}$ & & \\
\hline Year of Production & $\mathrm{n} / \mathrm{a}$ & & \\
\hline Date & $\mathrm{n} / \mathrm{a}$ & & \\
\hline Reel Information & $1 / 1$ & & \\
\hline Gauge & Super $8 \mathrm{~mm}$ & & \\
\hline Colour & Colour & & \\
\hline Film Polarity & Reversal & & \\
\hline Element & Camera Original & \multirow[t]{8}{*}{ Condition Notes: } & \multirow{8}{*}{$\begin{array}{l}\text { Ektachrome stock used } \\
\text { throughout. } \\
\text { Consistent cinch marks } \\
\text { on the emulsion side. } \\
\text { Vertical scratching on } \\
\text { the base side is closer } \\
\text { to the centre of the } \\
\text { frame- worse at the } \\
\text { head and tail. } \\
\text { This is the fifth film on an } \\
\text { Arleen Schloss film } \\
\text { compilation: } 2015.0002 .0106- \\
\text { 2015.0002.0111. }\end{array}$} \\
\hline Sound & Magnetic Stripe & & \\
\hline FPS & Unknown & & \\
\hline Aspect Ratio & 1:33:1 & & \\
\hline Length & $50 \mathrm{ft}$. & & \\
\hline Total Running Time & Unknown & & \\
\hline Archival Element & Archival Element & & \\
\hline Notes (internal use only) & $\begin{array}{l}\text { This is the fifth film on an } \\
\text { Arleen Schloss film } \\
\text { compilation: } \\
\text { 2015.0002.0106- } \\
2015.0002 .0111\end{array}$ & & \\
\hline
\end{tabular}

\begin{tabular}{|l|l|}
\hline $\begin{array}{l}\text { IDENTIFICATION/ } \\
\text { ACCESSION }\end{array}$ & \\
\hline Object Identifier & 2015.0002 .0110 \\
\hline CollectiveAccess ID & 15866 \\
\hline Acquisition Method & None \\
\hline Accession Status & None \\
\hline Related Lot & Arleen Schloss Gift (2015.0002) \\
\hline Access & Not accessible to the public \\
\hline Status & new \\
\hline
\end{tabular}

Figure 2.6

The fields requiring data entry for each film include: film title, related entities, related storage location, year of production, date, reel information, gauge, colour, film polarity, element, sound, frame rate, aspect ratio, length, total running time, archival element, notes, object identifier, CollectiveAcess ID, acquisition method, accession status, related lot, film wind, base type, stock manufacturer, date code, emulsion scratching, base scratching, perforation damage, 
edge damage, image fading, warpage, number of splices, leader information, overall condition, container information, and condition notes. Physical properties that are entered into the catalogue are meant to contribute to the analysis of the film's history. The level of damage is described by giving a rating of: Excellent, Good, Mediocre or Poor. These ratings can be further elaborated in the condition notes at the bottom of the record.

The physical condition of Anthology's film collections is of the utmost importance for ongoing and future preservation. The catalogue reinforces this purpose, as acetate film is formed from organic, biodegradable materials that can deteriorate quickly if not rehoused and stored properly. This is emphasized in the cataloguing process and can be one of the major deciding factors in selecting a film for a preservation project at Anthology. ${ }^{44} \mathrm{~A}$ film that is not threatened by deterioration will not be as high of a preservation priority when compared to the one that is in imminent danger.

\subsection{3i Naming Process}

Many of the films in the collection do not have official titles and, in most cases, only have handwritten notes created by Schloss at the time of their creation. These notes can include details of production such as location, time, or people involved. More often than not, only some of this information was recorded, and in certain cases the film boxes contain no information at all. Assigning titles to each work was one of the major challenges in archiving this collection. Square brackets were put on the outside of the majority of the titles, indicating that the titles were given to the work and are not official titles designated by the artist. This is also very common in home movie collections, which are not considered "art works" but rather documentations. The

${ }^{44}$ Ibid. 
majority of the titles entered into the catalogue were derived from Schloss's own writing, jotted on the outside of the film box. If the content were visible through a loupe during the film inspection process, and the work did not have a title or information on the outside of the film box, I would create a descriptive title based on the content and place it in square brackets. Films that did not have legible metadata or information on the outside of the box were considered "[Untitled]". Figure 2.7 and 2.8 show examples of film reels with very little information and that would be considered "[Untitled]". Films with legible metadata on the outside of the box had the metadata included incorporated into the titles. Figure 2.9 shows an example of a Kodak box where the metadata was incorporated into the catalogued title of the work because it was clearly written on the outside.

It is important to reiterate that none of these films were projected or viewed in their intended moving image form. Content was seen only through a loupe during the inspection process. Super $8 \mathrm{~mm}$ is a small gauge to view; therefore, if descriptive titles are inaccurate, the next person, who will digitize this collection, will be tasked with reassign accurate titles.

\subsection{3ii Language}

Language used to describe the physical condition of the film was provided by Kodak's The Book of Film Care, which has illustrations and detailed descriptions of the type of damage that can occur in acetate film. ${ }^{45}$ Handbook: Recommended Procedures for Motion Picture and Video Laboratory Services was another source that helped me with the understanding of certain technical details, such as the film wind, which is based on the generation and printing practices

\footnotetext{
${ }^{45}$ Eastman Kodak Company, The Book of Film Care, 2nd ed. (Rochester: Eastman Kodak Company, 1992), 40-61.
} 
of the film laboratory. ${ }^{46}$ By understanding the wind of the film, I was able to decipher the film element and whether it could be projected in the future.

\subsubsection{Compilation Reels}

Each film box contains between 10 to 50 feet of Super $8 \mathrm{~mm}$ film. The archival reels that the films were rehoused into come in two sizes: $150 \mathrm{ft}$. and $400 \mathrm{ft}$. Since the rolls of film consisted of a maximum of 50 feet, the majority of the collection was consolidated on compilation reels. Rehousing the films on compilation reels was done with the objective of saving space. However, each film included on a compilation reel has its own record and accession number. The maximum of six $50 \mathrm{ft}$. rolls of film were included on one $400 \mathrm{ft}$. reel. Each film is separated by white leader, differentiating one film from the other. Figure 2.10 shows an example of a compilation reel that contains 14 rolls of film because each roll included $10 \mathrm{ft}$. or less of film. Some of the film rolls contained metadata explicitly linking the content to an important event or performance; these were rehoused into individual $150 \mathrm{ft}$. reels (Figure 2.11).

\footnotetext{
${ }^{46}$ Association of Cinema and Video Laboratories, Handbook: Recommend Procedures for Motion Picture and Video Laboratory Services, Rev. ed. (Bethesda: Association of Cinema and Video Laboratories, 1982), 11-25.
} 


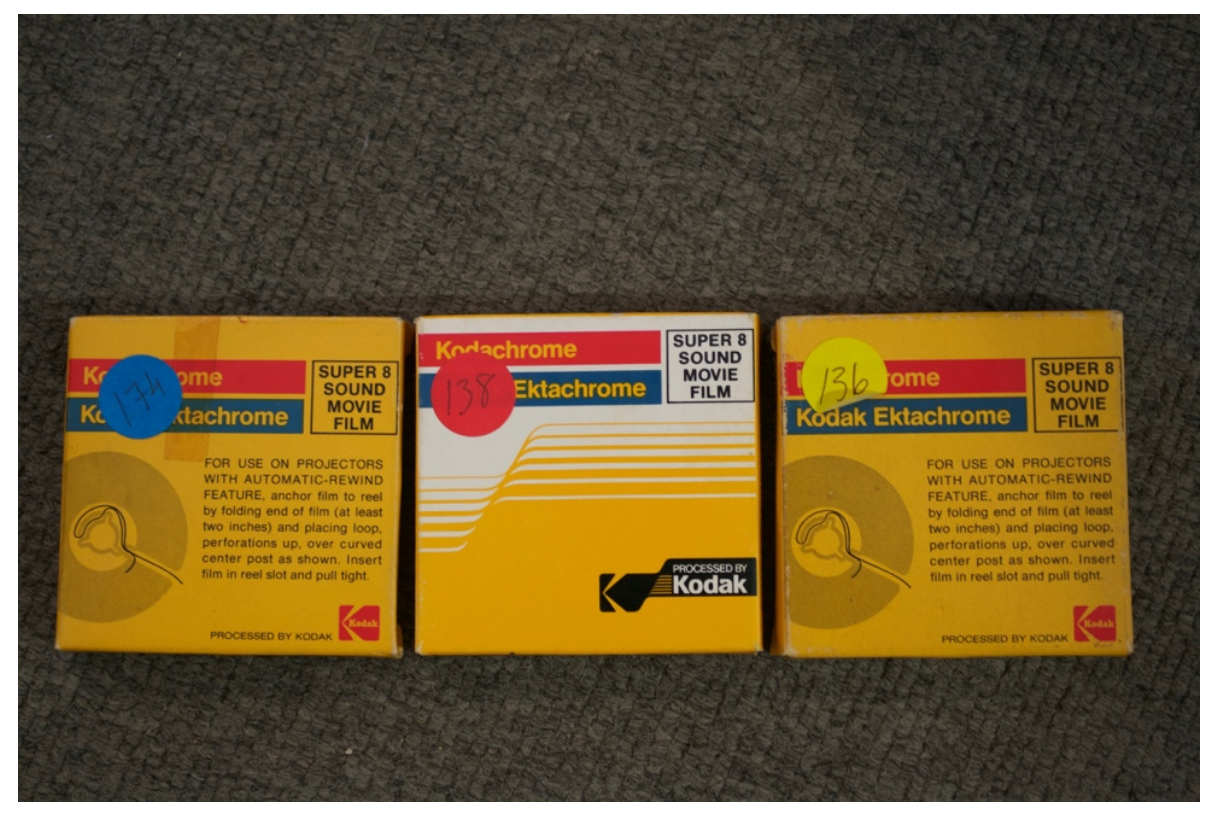

Figure 2.7

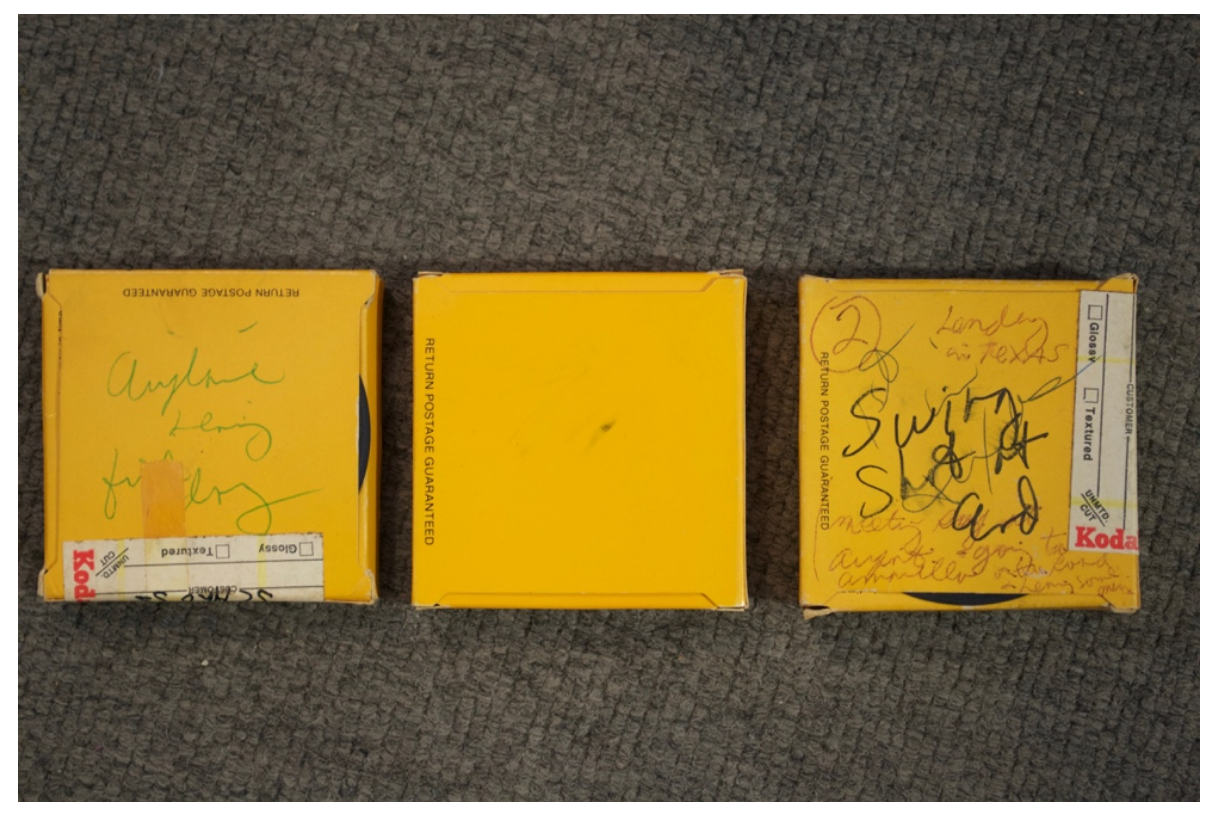

Figure 2.8 


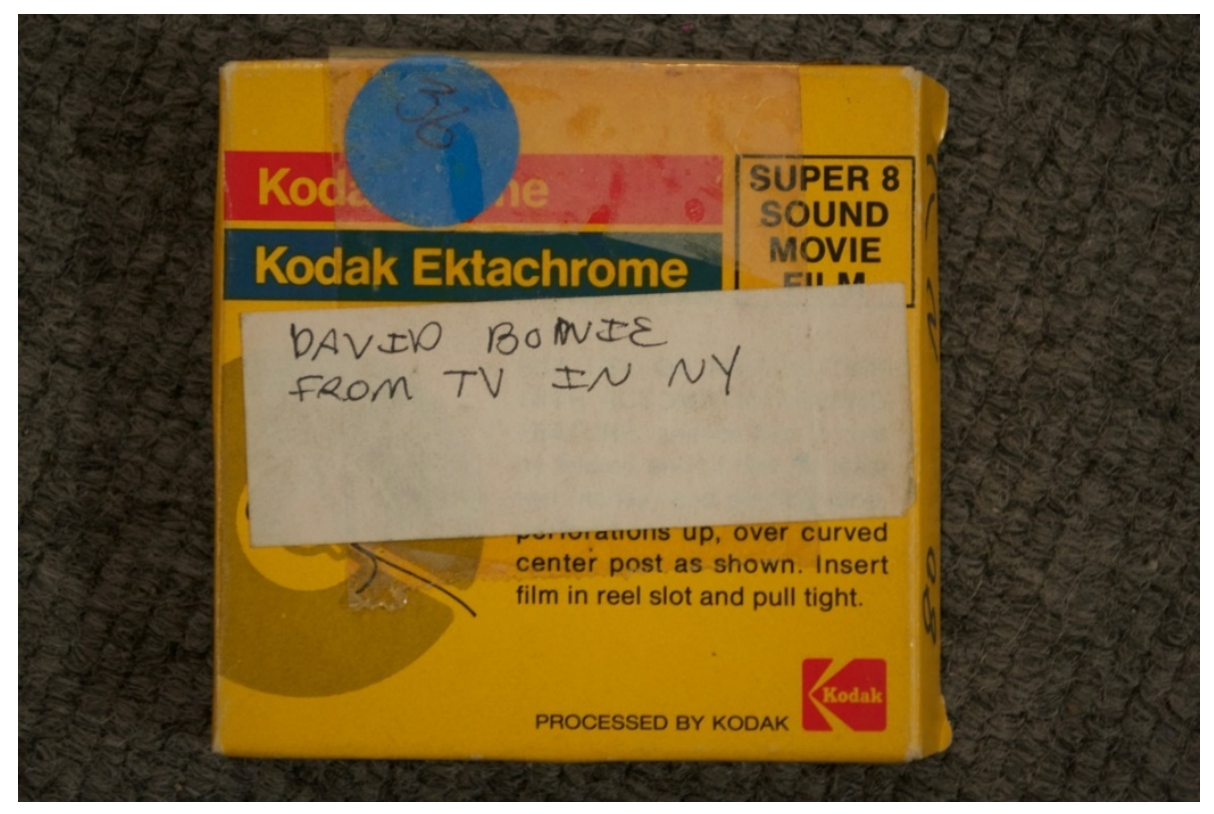

Figure 2.9

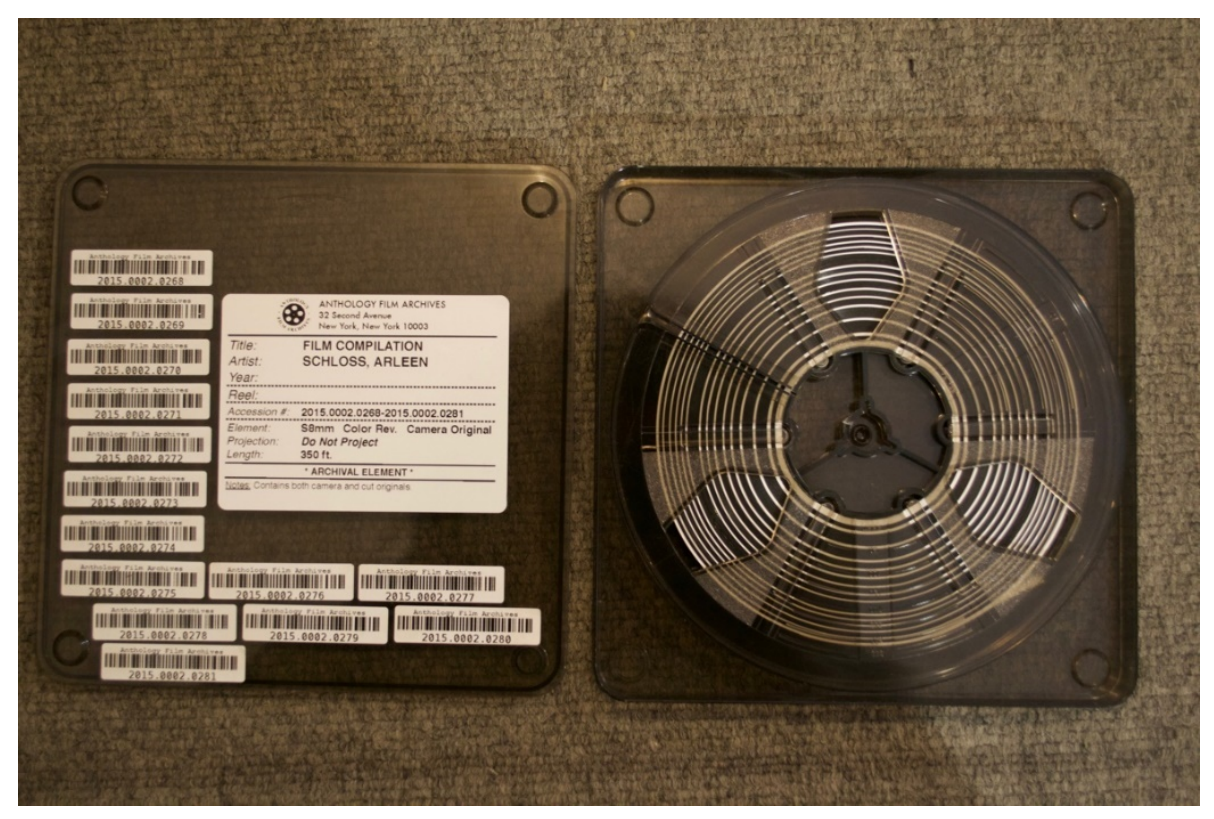

Figure 2.10 


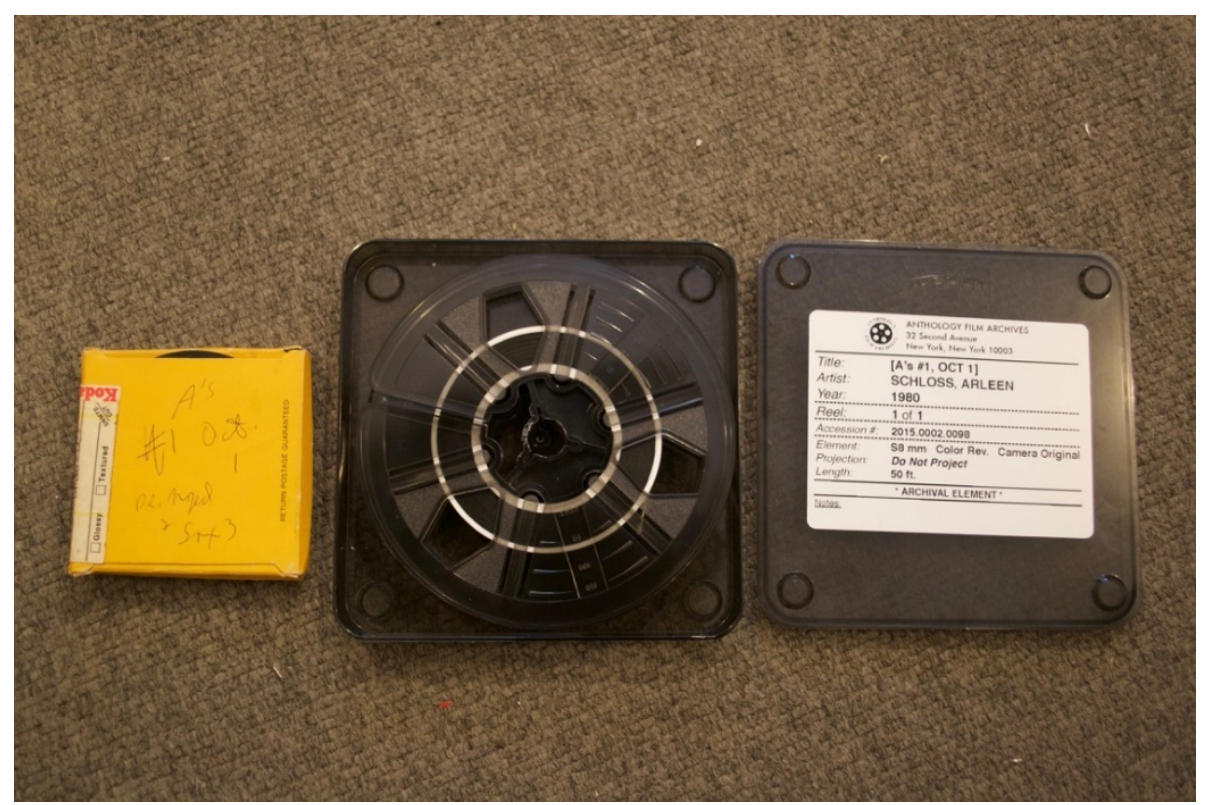

Figure 2.11

\subsection{Sound}

The majority of the films in the collection contain a magnetic sound stripe on the base side of the film. The deterioration of the sound is a concern that is optimistically decelerated by storing the films properly in a temperature-controlled vault and rehousing them in new archival containers. ${ }^{47}$ Digitizing the films would provide the most accurate representation of picture and sound together, because the frame rate for much of the collection is unknown. Shooting film with sound at 18 frames per second (FPS) rather than 24 FPS was commonplace, because it gave the filmmaker more shooting time due to the slower frame rate. Magnetic sound media can record sound at slower and faster speeds, providing that they can be played back at the same speed. Therefore, whereas it was possible for filmmakers to record sound at 18 FPS on their Super 8 film, the optical sound track requires a standard frame rate of $24 \mathrm{FPS}^{48}$ This can make

\footnotetext{
${ }^{47}$ John Klacsmann, interview by Traci Mark.

${ }^{48}$ Frank Romano, "The History of Frame Rates: Why Speeds Vary," Vanilla Video, December 16, 2012, accessed April 4, 2016, https://vanillavideo.com/blog/2012/history-frame-rates-why-speeds-vary.
} 
preservation a precarious task because magnetic sound track is no longer in production, necessitating the use of an optical equivalent. The introduction of an optical track into the preservation of an 18 FPS film with an original magnetic track would require the archivist to attempt to keep the sound playback accurate (in terms of a correspondence with the original 18 FPS sound) while using a 24 FPS optical track. Aligning picture and sound to remain faithful to the original version can be difficult. ${ }^{49}$ In this case digitizing the collection would provide the closest to the authentic picture and sound experience. John Klacsmann speaks about this issue in detail when he states

When we preserve super 8 , we're generally doing it on $16 \mathrm{~mm}$, and $16 \mathrm{~mm}$ sound film has to run at 24 frames per second because it has an optical sound track, and that's the speed that optical sound tracks have to run at. Then you get into a situation where you're essentially duplicating a frame every 3 frames because that's the way you get it to be at 24 frames per second, but appear as if it's running at 18 frames per second- the original frame rate. ${ }^{50}$

\subsection{Ethics}

Representing the Arleen Schloss collection in the catalogue accurately was the priority due to concerns of future access. When the project began, the entire collection arrived with a rough inventory of what kind of film was in each box. The box that my thesis project focused on was not accounted for, or given any titles like many of the other films in the collection. As I mentioned earlier, each work was titled during the cataloguing process, and frequently with square brackets around it. Early in the process, I was confronted with the ethical issue of interpreting each film, based on what I could see through the loupe if metadata on the box was illegible, and deciding on a title. With a collection that consists primarily of film documentation, this is a critical step that might affect future access for others who want to view and research the

\footnotetext{
${ }^{49}$ John Klacsmann, interview by Traci Mark.

${ }^{50}$ Ibid.
} 
collection. Without any content information displayed in the catalogue or elsewhere, titles are the only source of information about the film's contents. When accurate metadata was clearly written on the film box, it was included in the title since it was important in the cataloguing and preservation process to use Schloss's description as the identifier of her own work.

Appendix D consists of a list of the 180 films that were catalogued, including the general information about each title and its condition. This list is only representative of a portion of the films that were catalogued, specifically those focused on in this thesis. In total, there are just over 300 titles catalogued in the Arleen Schloss film collection.

\subsection{Preservation and Recommendations}

In the future, this collection can be used as a research tool for scholars studying this period in New York City's history. Due to the large number of items and the short length of each film, it would be beneficial to digitize the collection rather than preserve the films and make duplicate film copies. Since the majority of the collection consists of footage that Schloss took during an important time in the history of this city, having the films digitized would improve access to continue research on the collection and possibly begin the next step of the process: deciphering the content in the collection.

The collection also has the potential to be presented in a curated program. Since the films are camera originals and are the only existing copies, my recommendation would be to show them projected on digital video. 


\section{$\underline{\text { Conclusion }}$}

Cataloguing and rehousing of the Arleen Schloss Super $8 \mathrm{~mm}$ film collection was the first step in making this artist's films accessible for future use. This is only one part of Schloss's large body of work, and it will be up to future researchers to delve into the material and begin the process of identifying the people and places in her films, as well as the individual merits of each film.

Many decisions were made in the process of cataloguing, which were highly subjective and based on interpretation due to the limited availability of information on this collection and Schloss's artistic practice in general. This was an unforeseen obstacle and certainly the most challenging for this project. As an archivist, preserving the work and representing it in the most accurate manner is my highest priority. My intention is to begin a dialogue about Schloss's film work, which will hopefully expand to every part of her fruitful career and every medium and discipline with which she experimented. This thesis is representative of only one small part of a larger whole of Schloss's oeuvre that is waiting to be examined. 


\section{Appendix A: An Interview with John Klacsmann}

John Klacsmann has been the Chief Archivist at Anthology Film Archives since 2012. He was instrumental in the donation process of the Arleen Schloss collection of films and has spearheaded a number of preservation projects for the archive, as well as managing day-to-day operations. This interview took place on May 3, 2016 while I was doing my internship at Anthology, cataloguing and rehousing the Arleen Schloss film collection. This interview has been approved by Ryerson's Research Ethics Board.

\section{Traci Mark: If you could start by telling me about your background and how you began a career in film preservation?}

John Klacsmann: Sure. My undergraduate degree is in computer science and I started working in a film archive when I was an undergraduate student at Washington University in St. Louis. I'd already worked in the library, basically in a computer lab. When I found out we had a film archive, I switched my job to working there as a student worker. So, I've been interested in film preservation since around when I was a junior in college. Once I started working at the library film archive that was the beginning. From there I went to study film preservation at the George Eastman House (now the George Eastman Museum) and I did a film preservation for them on a fellowship after I graduated. I subsequently worked on a grant funded project for the museum with Technicolor dye transfer lab equipment that was ultimately shipped from Los Angeles to Rochester. So I worked out in Los Angeles with this material for a summer for the George Eastman House (now Museum). From there I went to work at Colorlab, which is a film lab in Rockville, Maryland who specialize in film preservation. I worked there for a little over two years. First as a film prep technician- basically leader-ing, or repairing film before duplication. Later I worked more as a film preservation technician, where I did the same thing, but also contact printing, optical printing, colour timing, quality control, and working more with not just anything that came into the film lab, but more specifically on film preservation projects from archives. Colorlab is really more specialized in small gauge film, including $16 \mathrm{~mm}$. So, I worked on a lot of $16 \mathrm{~mm}$, but also regular 8 , super 8 , and sometimes $35 \mathrm{~mm}$. I got a lot of experience there doing hands-on film preservation work. From there, I applied for a job here at Anthology and I started working here on January $2^{\text {nd }} 2012$ as an archivist, which is still my job today. I've been here now for almost four and a half years.

\section{TM: Is your job here at Anthology different than Colorlab? I'm assuming there must be some overlap.}

JK: There's some overlap, but here (at Anthology) I'm more managing the preservation projects, as opposed to doing the hands on work of the preservation, which is what the lab really does. It's sort of like the other side of film preservation. One side being the archive, who's securing the funds for the preservation, which might entail writing a grant or convincing someone that this work is worth preserving; figuring out what films need preservation and whether that's in your collection or out of your collection. Then finding the element that is going to be the preservation master and how you're going to actually preserve the film. Sometimes, of course you combine 
multiple elements. You're figuring out how to preserve the film and then sending that off to the lab with instructions, waiting, and then, working with the lab technicians when they get to your job to ensure it is done correctly. But the difference being I'm not sitting there and doing the contact printing like I was before for example. Sometimes I'll be repairing the film here, but often there won't be much repair so it's better for the lab technicians to do it. There's the archive and the preservationist, and then there's the lab. It's definitely different, but the two sides have to work together, so it really helps to know what they're doing at the lab and to have a really good concept of the process that they're going through, because that makes it a lot easier to manage, or more importantly even figuring out how to actually preserve the film.

TM: By interning here, I've noticed that it definitely helps to have some sort of background in film lab practices because then you fully understand the process. Hands-on work is the best way to learn, and there are very few places that do that anymore.

JK: Yeah, definitely. There's even less than when I got into the field. I've been in the field about ten years now and in the last five years there's been a real decrease in the amount of labs. Luckily, Colorlab is still around and they are one of the biggest labs in the country now.

I wouldn't trade my experience at the film lab for anything. My intention was never to work in a film lab when I went to school, I just sort of took that job because I needed a job. But I wouldn't trade it for anything because that's where I learned most of what I do nowadays, as far as my work as a film preservationist.

\section{TM: What made you interested in working with independent and experimental film?}

JK: It's just the kind of film I like. I think it's more interesting than studio film or narrative film. It's just the film I care about; it's the kind of films I think need attention. They need more attention because there's very little commercial incentive to preserve this work so unless someone goes out of their way to do it, it's simply not going to happen. I'm not so worried about Hollywood films or studio films being preserved because there's a great financial incentive to keep on making money off of that work, and the way to do that is by preserving it. But experimental film historically has never made anyone money, so it's sort of more of a cultural need. I find that work rewarding. I also just think that technical aspects of preserving this kind of work is more interesting because every project is different. You know, whether one is scratching on film, or hand painting it, or doing some kind of weird found footage project; figuring out how to preserve that work is always challenging and always different. So, it's less boring in my opinion.

TM: Beginning to speak about the Arleen Schloss body of films, could you tell me about the donation process of her films into Anthology's collection?

JK: Sure. It's a little bit of an atypical story in some ways because literally, someone knocked on the door, and I happened to answer. It was Sur Rodney Sur, who is an artist and a friend of Arleen's. So basically just a cold call in a way. He just knocked on the door and said (paraphrasing) "I have all these films by this artist Arleen Schloss and would you be interested in taking them for Anthology?". He explained that another portion of the archive was at NYU, but 
he thought that the films might be better here. I didn't really know Arleen's work, and I didn't really know her name either but I had heard about A's. It didn't take much research from the time I met Sur to figure out that this would be an interesting collection to take in. Basically from there it was pretty simple, Sur Rodney Sur was working with Arleen pretty closely and once we decided to take the films it was simple. He had already done a basic inventory, we sent him the agreements and he dropped them off right after that.

\section{TM: Does she (Arleen) own the rights to the films?}

JK: I'd have to look at the agreement, I don't remember exactly. I have a feeling that she donated the rights too, but I'd have to look at the agreement.

\section{TM: Could you talk about the challenges of preserving super 8 reversal and the challenges one could face when preserving it?}

JK: Yeah, super 8 in my opinion is probably the most challenging gauge to preserve. There's several reasons for that. The first is, I don't think that super 8 is always the sharpest film medium because it's not pin registered in a way that most film gauges, even regular $8 \mathrm{~mm}$ are. It uses a pressure plate in the cartridge, so for that reason, I think that even when you do the best $2 \mathrm{~K}$ scan, people can be a little underwhelmed by how it looks. Because when you're doing a scan of that quality, the actual look of the film is being revealed on a level that has maybe never been seen before. You can project it huge, and it's extremely sharp and maybe a little bit more of the flaws are revealed that wouldn't be seen if you were projecting the film relatively small and dimly on a super 8 projector. So I think people tend to be a little bit underwhelmed by the results and think that the film looked differently than they're seeing now. When actually, yes, it might look differently, but through the preservation you're seeing what's always actually been in the film.

The other real reason it's challenging is when filmmakers shoot at 18 frames per second, with sound, on a magnetic stripe on the film. That tended to be a pretty common thing that super 8 experimental filmmakers did in the $80 \mathrm{~s}$ and $90 \mathrm{~s}$, meaning a lot of them were experimenting with incorporating sync sound into their work. A lot of them were shooting at 18 frames per second because you get a little more footage out of a single cartridge than you would if you shot at 24 frames per second. The problem is that when we're preserving a film that was shot at 18 frames per second with sound, we generally have to do a frame rate conversion to 24 frames per second. When we preserve super 8 , we're generally doing it on $16 \mathrm{~mm}$, and $16 \mathrm{~mm}$ sound film has to run at 24 frames per second because it has an optical sound track, and that's the speed that optical sound tracks have to run at. Then you get into a situation where you're essentially duplicating a frame every 3 frames because that's the way you get it to be at 24 frames per second, but appear as if it's running at 18 frames per second- the original frame rate. That leads to a little bit of complications as far as the way the film looks. It's not perceptible to most audiences but there are certain kinds of shots where it is noticeable to some degree. The movement just doesn't look like it used to because you're having that extra frame duplicated every three frames. You also can run into some complicated syncing issues. Cause again, you're duplicating frames and having to resync this track that was running at 18 , and now running at 24 . And finally, sort of going back to the first point, mag stripe sound on super 8 generally doesn't sound very good. It's hard to get a transfer off of that little tiny mag stripe that actually sounds good. Part of that is because I think 
that the mag stripe technology is just not the quality that we're used to in other mediums. I think that part of the reason is because there are very few labs that can do a really good job transferring super 8 mag stripe anymore. For these reasons, I think preserving super 8 can be the most difficult.

\section{TM: What is the most common way to preserve super 8? A blow up or presenting on video and having the film digitized?}

JK: Well, it used to be that you would do a blow up with an optical printer onto $16 \mathrm{~mm}$. That was the standard preservation method for super 8 and regular 8. Some people maybe would claim that you should go to $35 \mathrm{~mm}$, but in my opinion that's not something that most archives did. Certainly not something that Anthology did. But it's very expensive to do optical printing- it is a frame-byframe rephotography. In 2016, there are very few people who are doing regular 8 or super 8 blow ups to $16 \mathrm{~mm}$ photo chemically. There's just not that many optical printers or optical printing technicians that are doing that work anymore. I'd say in the last four or five years, I have been a big proponent, and I think others are following, of preserving super 8 or regular 8 using a digital intermediate. Which means we scan the super 8 or regular 8 film at $2 \mathrm{~K}$ (or soon perhaps $4 \mathrm{~K}$ ) frame by frame, and then we output the scan back to $16 \mathrm{~mm}$ film. There are a couple reasons why we're doing it that way. One: I think the results are better. I think the scans are much sharper, and it allows you to do a little bit of correction on the digital side before you go back to film. Two: again, there's very few people that are doing optical blow ups photo chemically. It's basically that these are the tools that are available now and they are digital. I think the results are very good. On selected project we're also digitizing super 8 film and regular $8 \mathrm{~mm}$ film and not going back to film. I wouldn't necessarily call that preservation, but finally we can digitize these small gauge films to such a high quality that the presentation is very good. Even if the film is not preserved technically, we're able to exhibit the film on a quality we were not able to previously. So that's been a change. Again, it's a similar process, it's just instead of going back to film, you might encode a digital cinema package (DCP). So we're able to exhibit super 8 film as a $2 \mathrm{~K}$ video now, which can look pretty good. We did that recently with Charlie Ahearn's Deadly Art of Survival, which was a super 8 feature. In that case, sure, we weren't able to afford going back to $16 \mathrm{~mm}$ film for an 80 minute movie, but at least we were able to make a $2 \mathrm{~K}$ DCP and show it at any contemporary cinema. Which is a pretty big thing for a film that was shot on super 8 and has been unavailable for decades because no one exhibits on super 8 anymore really

\section{TM: While I'm winding through Schloss's body of work, I can see the images, but I don't know what the sound consists of. Is there any way we can prevent the deterioration of the magnetic stripe while rehousing?}

JK: The best to prevent deterioration is just by storing it properly. There's nothing that you can do on the bench to help it really. Unless it had mold or something, then you clean the mold off. But the way to prevent deterioration is really through proper storage. Part of that is happening on the bench because you're rehousing the films and you're adding leader and making sure it's taped down properly and not loose on the reel. So that's part of rehousing and storing. The main way is just by storing it in proper humidity and temperature. You could argue that digitizing the mag stripe now would be another way to prevent deterioration. That's not something we've really done here because I don't really think we're able to digitize every single super 8 reel. And again, 
you also run into some complications with getting a good transfer off of a super 8 mag stripe, it's a hard thing to do. But yeah, I think the main way is through conservation and proper storage.

TM: Can you talk a little bit about Anthology's catalogue and how it's designed? It's clear that the catalogue is concerned with the physical object more so than the content. I've noticed that's different from other moving image archives. When was that choice made and why?

JK: The choice about how to catalogue?

TM: Yes, how to catalogue and not necessarily using a metadata standard.

JK: Well we moved over to a digital catalogue around the time I started. Lots of the decisions about what kind of software to use were made before I worked here. We use a system that is not entirely one I would have chosen, for better or worse. But the structure we use is largely based on how we've catalogued film since we opened in the 70s. Because the goal, of course, is to get all the materials that have been in the collection into this new digital database. We had to rely on some of the standards that we previously set to make that possible. Of course in the 70 s they weren't thinking about standards or metadata or anything like that. Our collection is also a little bit unusual anyway. You know, it's easy to set up a standard for cataloguing motion picture film when your main concern is studio films. I think that has been others focus for the most part. But then when you look at our collection you realize that all these choices that other people made about how to catalogue film don't really apply to our collection because we don't have production companies and casts and, you know, it's just a different kind of work completely. Even the terms and vocabularies that they're coming up with for what a film is often don't apply to our collection. We sort of had to develop our own vocabularies. That being said, even though our catalogue is a little esoteric, we did review lots of the other standards and tried to incorporate as much of the language and terminology as we could, knowing that it was not going to match exactly, but that it would be similar in lots of cases. As far as cataloguing the content, I think that could happen in the future. I think it's a little bit of a different job in lots of ways. I mean, it is still cataloguing. But yeah, it's true, we're mainly concerned with the condition of our film and figuring out what it is physically. Not so much the history of the production or what appears in it because I think that stuff can be researched relatively easily in lots of cases. The priority is to figure out the condition of the collection is and figuring out what we actually have as opposed to what's in what we have.

TM: For my thesis, I'm specifically focusing on Schloss's Ektachrome and Kodachrome 50 foot reels that we're still in the original boxes that they came in from the film lab. One of the thing's I've been noticing is that the metadata- or more so handwritten notes, that Schloss wrote on the boxes, are unclear or indecipherable in most cases. I'm sure she didn't predict that her work would end up in an archive where it would have to be assigned titles. I don't really think she saw this as a finished body of work, but more so documentations. Cataloguing the material has been challenging at times with a task as simple as assigning a title to a work. Essentially, I treated it as a home movie collection and I've tried to assign descriptive titles. However, if I can decipher the words on the box, I'll try to include it in the title because I feel as though that gives her (Schloss) agency. This was an ethical issue 
that I didn't expect because it became about me interpreting this work as well, and in a way, controlling how it can be accessed and seen in the future. I was wondering if you have ever dealt with a situation like that, especially in a situation where there are no clues, and not many sources on the material. Especially because everything I've found that's been published about Arleen has specifically focused on her performance work, not her films. And if you haven't been a similar situation, what would you do if you were put in this situation?

JK: Well first off I think the act of film preservation is all about interpretation, so that's not surprising. It's the kind of thing we run into everyday, whether it's assigning a title or making a decision about how a film is supposed to look or should look through colour timing, or using a liquid gate, or not using a liquid gate. So it's all about interpretation. But I think you kind of nailed it when you said that you didn't think she saw this as a body of artwork. I think you're probably right. I think there's a difference between finished work and footage and I think you're right that a lot of this material is footage. Maybe it was intended to be made into a finished work or maybe not, and that's OK. It doesn't really matter because it's important either way. But it's important not to get caught up in that, I mean, she did make experimental films which are completed works and we have them in the collection. There's one we had even before we even took in this collection and then there's everything else. Lots of archives don't take outtakes or footage, but in this case we did because I think that the materials here are historically important. So we sort of made a judgement call. As far as figuring out what it is; this is just the beginning or very long process that could unfold over the next decades. You're taking the first step and making it digestible to someone in the future. But do I expect us to understand every reel and know what it is? Ideally, yes. But that's not what I expect for a collection of this size and one that is this complicated. The important thing is, once you're done, everything will be indexed to some degree and then in future we can begin the long process of digitizing or identifying etc. Yeah, we might not have the best assigned title now, but again it's very hard to view what you're looking at on the light table, besides a sort of light box, frame-by-frame thing. In the future, based on the index, we can start digitizing materials and actually viewing them and then identifying people or places. It's just a small part of a long process and this first step is the most important step in many ways because without indexing to even a basic degree, we don't really know what we have. So at least now the collection will be little bit more accessible to whomever will pick it up in the future.

TM: One of the first things we talked about when going through that specific box of films was putting all the films on compilation reels because of limited space, and because it doesn't make sense to put a $50 \mathrm{ft}$. reel of film on an $150 \mathrm{ft}$. archival container. I was wondering if that has ever been done before in the collection?

JK: Yeah, we did it with a collection of Hollis Frampton materials. We call it the Hollis Frampton footage collection, which was maybe what I was getting at earlier about footage. I wouldn't necessarily do a compilation reel for work I saw as being finished or completed work. We have a lot of Storm de Hirsch's super 8 films, which are all separate even if they're small because they're finished super 8 works that she distributed and showed. But in the case of the Hollis Frampton footage collection, it came to us from his widow clearly as footage and unfinished bits and pieces. So yeah, for space reasons, and also for comprehension of the 
collection, things were combined. Space is a serious concern in any film archive. To put ten foot pieces of film in $400 \mathrm{ft}$. cans...it's just not possible for something that can live on, just as well, on a compilation reel. That's where the indexing and cataloguing is important as well, because maybe it's a little more challenging to get to that piece of film in the future, but if it's catalogued well it's not much more of an effort. That's the only other situation I can think of immediately where we did a similar thing. It's very similar in a lot of ways because of course we have Frampton's finished works, which are indexed, preserved and catalogued regularly. And then we have this footage collection which consist of comp reels and assigned titles given by someone who really focused on that collection and worked on it in depth, much like you are with this collection.

TM: Is the Hollis Frampton footage collection the only case where you've had a personal archive of this size in Anthology's holdings? Or is the Arleen Schloss collection the largest in terms of item numbers?

JK: Another similar situation, bigger I'd say, is our collection of Judd Yalkut's films. We have all his original, or most of his original films, as well as his print collection, which would be his own prints and other prints he collected from others. As well as all his outtakes. So that's a little bit of a bigger collection, just because I think he made more work and he worked on $16 \mathrm{~mm}$ and he didn't throw anything away. But the Arleen Schloss collection is definitely, in terms of item numbers, a large ish collection for us. The Yalkut collection is bigger, more items and it's $16 \mathrm{~mm}$ so it takes up more space, but Arleen Schloss's one of the larger collections too.

TM: Lastly, can you discuss the criteria that you go through to select films for preservation. This obviously vastly differs from each institution. For example, with Hollywood, there might be more of an emphasis on profit, but here I feel like it's more about cultural significance as well.

JK: I think the main thing we think about is what films are in need of preservation. We have a pretty good idea of the collection and what is priority as far as what has vinegar syndrome or what is fading. Or if all we have is the reversal original of a title, or all we have is the reversal original and a reversal print. Meaning items that don't have negatives is another concern. So it's basically what's in need the most. Of course cultural significance comes into play with that. Personal tastes also come into play. I think anyone who says that it doesn't is lying. But that being said, I preserve lots of films that I personally don't like as well. My point is, I'm not completely unbiased; I try to preserve what I think needs to be preserved. There are lots of things that I investigate and find out, (for example) if there's a negative of that film already. The fact that there is a negative makes it a little bit less of a priority to me than something where there are zero negatives of, or that's completely inaccessible. So it's definitely not about profit but more just about what physically is in need. Then maybe a little bit of personal tastes sprinkled in there.

\section{TM: Also if you're applying for a certain grant.}

JK: Well yeah, of course there's a strategy of applying for grants and packaging preservations in a way that you think will get the most funding. That comes into play as well. Sort of having a queue or timetable of what you're going to be applying for next. A lot of what we're going to 
apply for we know, a year or years in advance. We just applied for two grants for film preservations and there might be one more for another granting organization but basically our applications are over for the year. I know what's going to be coming up for the next year or two years based on what's already been funded. I'm already thinking about what I'm going to apply for next year which is not going to happen until February or March of 2017. I have a short list in my mind. There might be some new discoveries or new things that come into my mind, but I'll start planning ahead now about what I could apply for in 2017. It's really just about knowing your collection or knowing what's out there, or what might need work and thinking about the best way to get that work funded and preserved. 


\section{$\underline{\text { Appendix B: Arleen Schloss's Curriculum Vitae }}$}

\section{ARLEEN SCHLOSS}

330 Broome Street

New York, New York 10002

(212) 431-9464

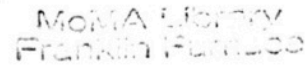

? i 61995

Antetio

Born in Brooklyn, New York, 1943

Lives and works in New York

EDUCATION

New York University, BA, 1965

Art Students League

Bank Street College

Parsons School of Design

\section{GRANTS AND AWARDS}

1989 Media Bureau, video

1988 The Kitchen/8mm Video Council, Canon Corporation

1987 Ace Award, Manhattan Cable Television

1985 National Endowment for the Arts/Allied Productions

1980 Creative Artists Program, New York State Council on the Arts, Multi-media Soho Tech Award, A's Salon series

1975 Latin American Resources, Color Xerox

1966 Ford Foundation, Painting

1962 Miss Brooklyn

SOLO EXHIBITIONS

1985 "The City Universe Project", La Galleria Del'Occhio, New York

"Installation", The 13th Hour Gallery, New York

"A's Posters" Shuttle Gallery, New York

1984 Video Installation, Public Image Gallery, New York

1982

1976

1975

1974

1968

"Projects", Hansen Fine Arts, New York

"Generations", Popular Photography Gallery, New York

"Diagrams", Rhush Rhees Gallery, Rochester University, New York

"Fiber Works", Dord Fitz Gallery, Amarillo, Texas

"Paintings", Clyde Mack Gallery, New York 
GROUP EXHIBITIONS

1989

"China"

The Asian American Art Center, New York

"Land Mines"

The Gas Station, New York

1985 "Thought Objects"

Cash Newhouse Gallery, New York

"Art of the 1970's and 1980's"

Aldrich Museum of Contemporary Art, Ridgefield, Connecticut

"New York East Village Art Situation 85"

Accademia Di Belle Arti, Museo Di Arte

Moderna Di Catanzar, Italy

"Artibus-Sacrum"

Kunstcentrum, Arnheim, The Netherlands

"States of the Art"

Todd's Copy, New York

"Massive Political Group Show II"

$A B C$ No Rio Gallery, New York

"Wacs-Bams"

Freddy the Dreamer Gallery, New York

1984 "Down by Wall"

1 Stop, New York

"Audioworks"

Koller-Moller Museum, Holland

1982 "Live to Air"

produced by Audio Arts, Tate Gallery, London

"Earworks: an Exhibition of Musical Scores and Sound Art" Grommet Gallery, New York

"Artists' Books"

Ben Shawn Gallery, New Jersey

"Slides"

Red Spot Gallery, New York

1981

"XVI Biennale of De San Paolo, Brazil"

1980 "Bookworks: New Approaches to Artists' Books" Traveling show, sponsored by Franklin Furnace

"S.T.I.P."

Franklin Furnace, New York

1979 Modern Art Galerie, Vienna, Austria

"Sound-Medium Der Bilden Den Kunst"

Dany Keller Galerie, Munich, West Germany 
GROUP EXHIBITIONS CONTINUED

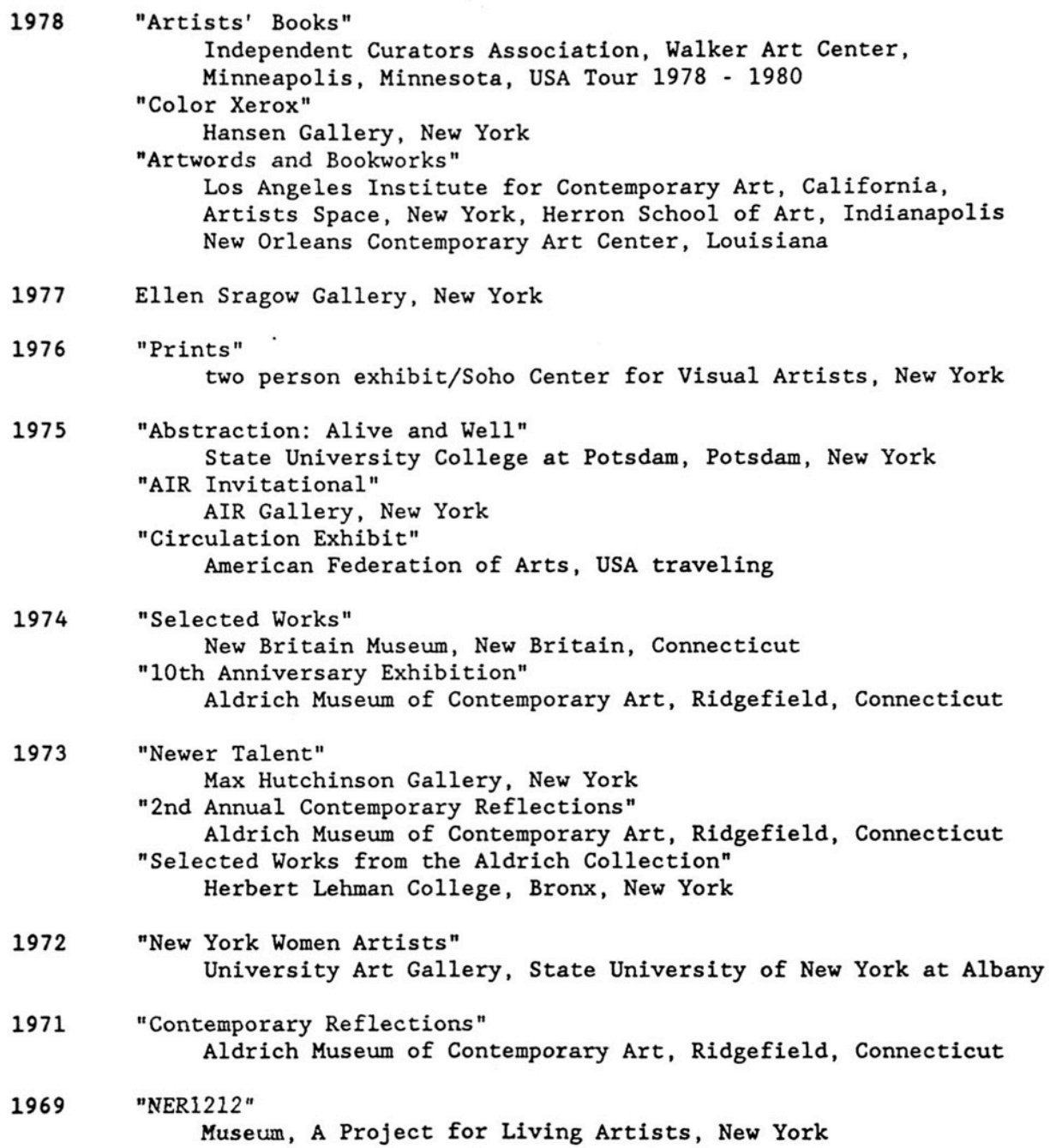


PERFORMANCES

1987

"Loveletters"

performance opera, music by Jack Smead

$A^{\prime} s$, New York

1986 "A.E. B1a B1a B1a"

media opera, music by Butch Morris

choreography by Christa Gamper

sculpture by the Rivington School

Ars Electronica Festival for Art, Technology and Society

Brucknerhaus, Linz, Austria

"A.E. Bla Bla Bla"

media opera excerpts

Darinka, New York

1985 "Flying Letters"

performance event

Tompkins Square Park, New York

"4 Xample"

multi-media performance

Experimental Intermedia Foundation, New York

"A Spontaneous Harmony"

multi-media performance

Club 8 BC, New York

1984 "The Letterwoman Show"

staccato opera \#10

The Shuttle Theatre, New York

"I Land in the Sky"

performance event

Club Area, New York

1983 "The Longest Day"

performance, Summer Solstice Event

Riverside Park, New York

1982

"How She Sees It By Her"

multi media performance

Vehicule Art, Montreal, Canada

Fashion Moda, Bronx, New York

Tin Pan Alley, New York

Pyramid Club, New York

Club 57, New York

Summer Solstice, Lincoln Center, New York

Storefront for Art and Architecture, New York 
PERFORMANCES CONTINUED

1981

"The New York to the Performance"

multi-media performance,

Stadt Galerie im Lenbachhaus, Munich, West Germany

"The Live Performance Story from A to $Z$ (Monster Mash)"

performance retrospective

Greenspace, New York

"How She Sees It"

performance

Westbeth Theatre Center, New York

1980

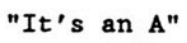

"1008 Synthetics"

performance tour, music by Blasse

Club Moon, Berlin, West Germany

The Lerm Studio, Dusseldorf, West Germany

Modern Art Galerie, Vienna, Austria

"La Nuit Parcourt La Ciel"

Poetry festival in a coal mine

Liege, Belgium

"A at B to Z"

staccato opera \#9

Cirque Divers, Liege, Belgium

"TV as des Beaux Yeux"

staccato opera \#8

$A^{\prime} s$, New York

"The 12th Annual Sound Poetry Festival" performance

Washington Square Methodist Church, New York

"F10 No"

multi-media performance

Club Plugg/The Space, New York

1979

"It's $A$ at B"

multi-media performance,

Vienna Biennale, Vienna, Austria

"It's A at B"

staccato opera \#7

Basel Art Fair, Basel, Switzerland

"It's Z"

staccato opera \#6

Castle Legenfeld, Krems, Austria

"It's A at Tea"

staccato opera \#5

Turi Werkner Studio, London, England

"A Scrab/Rhythm"

staccato opera \#4

Dany Keller Galerie, Munich, West Germany

"Adventure A"

staccato opera \#3

The Lerm Studio, Dusseldorf, West Germany

"Snapsteps"

performance series

Ear Inn, New York 
PERFORMANCES CONTINUED

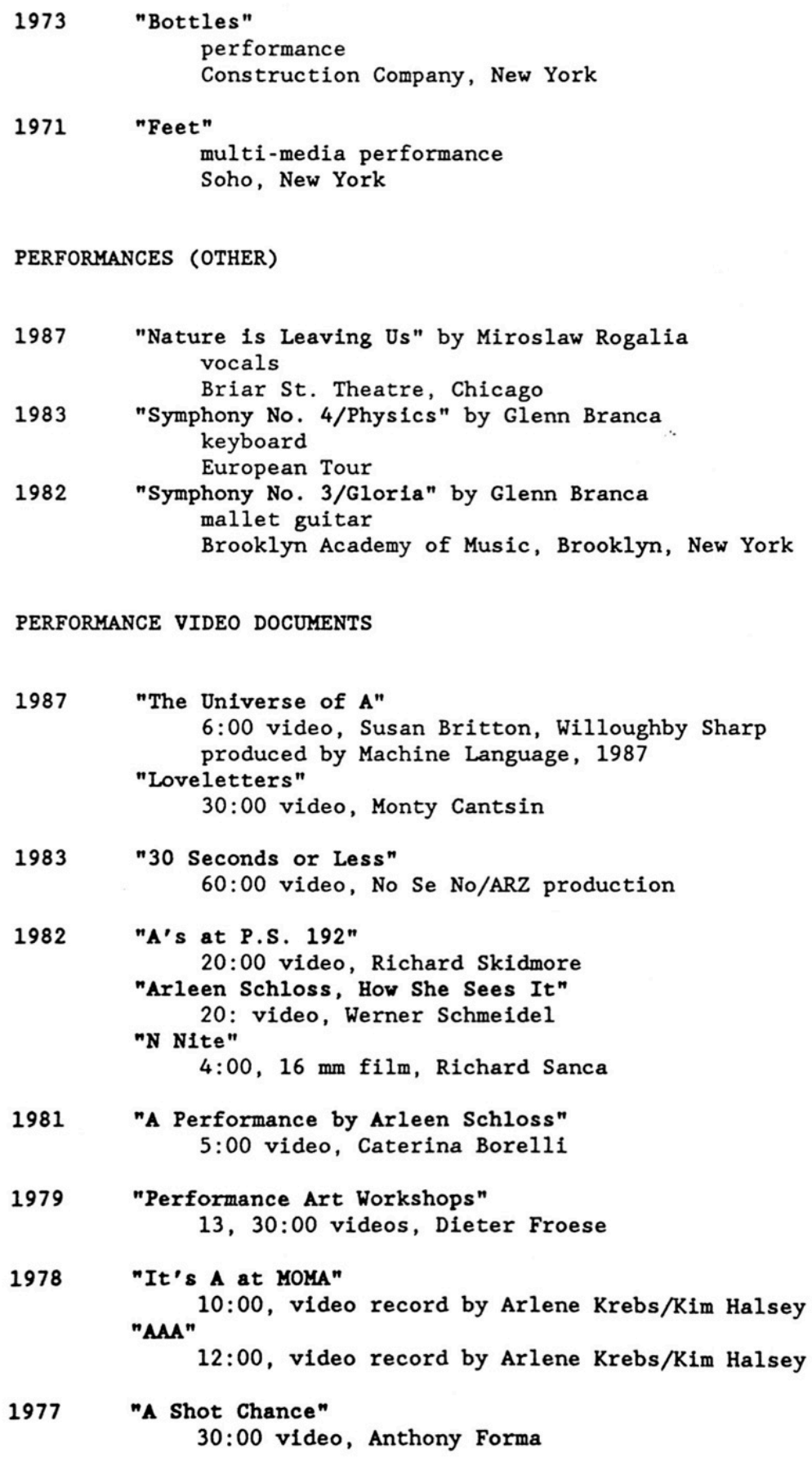

PERFORMANCE VIDEO DOCUMENTS 
PERFORMANCES CONTINUED

1978

"It's A at MOMA"

multi-media performance

Museum of Modern Art, New York

"Rhythm \#5"

performance event

Skowhegan School of Art, Skowhegan, Maine

"A Claire"

staccato opera \#2

Franklin Furnace, New York

"AAA (and the alphabets)"

multi-media performance

Robert Freidus Gallery, New York

1977 "A Shot Chance/Rhythm" staccato opera \#1

The Kitchen, New York

"Rhythm"

performance

Betty Parsons Gallery, New York

"A Chorus"

performance

The Other End Cafe, New York

Hedda Sterne Studio, New York

"At Midnight"

performance

Galerie Do Do, New York

"Bottles"

performance

Robert Freidus Gallery, New York

1976

"Homage to Alexander Calder"

performance

American Theatre Laboratory, New York

"Words and Actions"

performance

Construction Company, New York

"Sounds and Actions"

performance

Contemporary Arts Museum, Houston, Texas

1975 "Snap"

performance

University of Rochester, New York

Betty Parsons Gallery, New York

"Words and Music"

performance, music by John Smead

Bykert Gallery, New York

"Jade"

performance, music by Cigaret

Circle K Ranch, New York 
PERFORMANCE/COLLABORATIONS

1989

"10 Minutes to A"

writer, director

performed by Rolando Vega, Pyramid Club, New York

1988 "A Club"

co-producer

new music series, Peggy Sue's, New York

1985

"A's Salon"

co-producer/Allied Productions

"Pool", previews, A's, N.Y.

1984 "Limbo Refugee Camp at A's Relocation Center"

co-producer/Limbo Lounge,

performance series, A's, New York

$1983 \quad " 00: 26 \times 00: 26 "$

co-producer

No Se No, performance cabaret, Roadrunners Club, New York

"The Fastest Show on Earth"

co-producer

ARZ productions, performance event, Danceteria

"A's in Public Schools"

co-producer

Children's Art Carnival, performance events

P.S. 192/185, New York

"99 Nights"

co-producer

performance series, No Se No, New York

"Nancy Girl is A"

writer, director

performed by Nancy Vega, Terminal Show, New York

1982

"Performance $\mathrm{A}$ to $\mathrm{Z}$

co-producer

performance series, Storefront for Art and Architecture, New York

"N Night"

produced

multi-media performance event, $A^{\prime} s$, New York

"A's des Refuses"

co-producer

live performance cable television series Club Armageddon, New York 
PERFORMANCE/COLIABORATIONS CONTINUED

1981

"Nobody Else But Us"

co-producer

PIM Magazine, performance event, $A^{\prime} s$, New York

"Monumental Show"

coordinator

performance event, Gowanus Memorial Artyard, Brooklyn

1980 "A's at Snafu"

producer

performance/new music series, Club Snafu, New York

"A's in Celebration of the 75th Anniversary of the Staten Island Ferry", co-producer

performance event, Staten Island Ferry, New York

1979 "A's"

founder

weekly series featuring new music, performance art, media

arts, visual exhibitions, weekly through 1981, intermittent activities though the $80^{\prime} \mathrm{s}$, including A's Salon, A Gallery, A's Sculpture Garden. Presenting works of over 1,000 artists including Joseph Beuys, Andy Warhol, Mike Bidlo and Richard Hambleton as well as collaborating curators, Jack Tilton and Gracie Mansion. New music and the performing arts include Linda Burnham, Eric Bogosian, Phoebe Legere, Glenn Branca, The Del Lords, The Dictators, BoBo Shaw and Julius Eastman. A's productions expanded to varying locations - see 1980's.

1978 "It's 7Up"

writer, director

performed by Musawwir Gymnastic Dance Co., "Smack" American Theatre Lab, New York

conceived and directed

performed by Musawwir, SUNY at Purchase, New York

1977 "A Shot"

conceived and directed

performed by Musawwir, Walden School, New York

1976

"An Evening of Poetry"

producer

with Betty Parsons and Skye Vermont, A's, New York

1974 "Smack 4 J"

conceived and directed

performed by Musawwir, Washington Square Methodist Church, New York 
BROADCAST

1989

1988

1986

1985

1984

"Alphabets/Hand Paint" director, aired Nickelodeon, MTV networks produced by Todd Kessler productions

"Hello Vienna/Hello Austria" featured artist, aired ch 31 and Austria TV produced by the ORF, Austrian television

"I.D./It's Dance" Opening Title Sequence/Theme song, aired WWOR/MTV networks, produced by IRS records

"Glenn Branca Symphony No. 4/Physics" super 8 video, aired Nightlight TV

\section{"Bro Man Bro"} conceived and directed tri-boro closed circuit teleconference aired ch 25, produced by the Bronx Council on the Arts, Board of Education

"It's A Live Laser" video/aired annually Nightlight TV,

\section{"A.E. Bla Bla Bla"}

media opera, aired European Television, produced by the ORF, Austrian Television

"The Willoughby Sharp Show"

featured artist, aired ch J, MCTV

"It's A Live Laser"

video, aired Swedish TV, produced by Nattovning

"Glenn Branca Symphony No. 4/Physics" super 8 video, aired French TV

"Radio Unnameable"

guest artist, aired WBAI, produced by John Kalisch

"Fashion Moda Radio"

guest artist, aired WBAI, produced by Isaac Jackson

"Meet the Composers"

guest artist, aired WKCR

"The Longest Day"

Summer Solstice Theme song, aired annually, WNYC produced by The New Wilderness Foundation 
BROADCAST CONTINUED

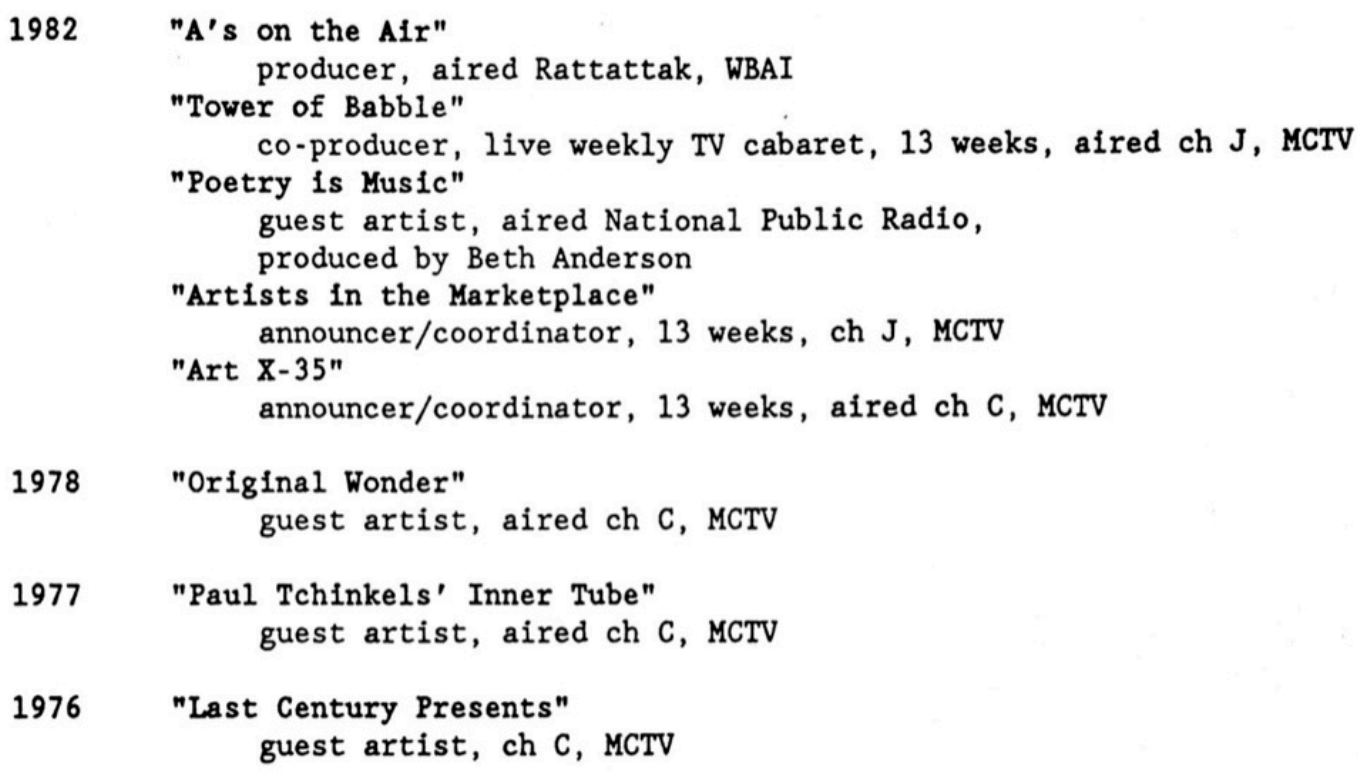


VISITING ARTIST AND LECTURES

1989 Artist in Residence, audio, Studio Pass/Harvestworks, New York

1988 Artist in Residence, video, New York Foundation on the Arts, New York

1987 Guest Lecturer, Art Institute of Chicago, Illinois

Video Instructor, Center for the Media Arts, New York

Language Arts Instructor, Public School 75, New York

1986 Announcer/Master of Ceremonies, Ear Magazine Benefit, Club 4D, New York

1985 Artist in Residence, video, Science Faction Corp., New York Guest Lecturer, Artist in the First Person, New York Univeristy, New York. Panelist, Pennsylvania State Council on the Arts, Harrisburg, PA

Panelist, Painted Bride Performance Space, Philadelphia, PA

Panelist, Just Above Midtown, New York

Artist in residence, audio, Studio Pass/Harvestworks, New York

1983 Announcer/Master of Ceremonies, Ear Magazine Benefit, St. Bartholemews

Church, New York

Artist in Residence, audio, The Sound Foundation, New York

Announcer/Master of Ceremonies, Club Underground, New York

Announcer/Master of Ceremonies, No Se No, Danceteria, New York

D. J., Kwok Gallery, New York

1982 Moderator/Co-producer, Is Performance Art?, Artists Talk on Art, New York Artist in Residence, ESL, Childrens Art Carnival, New York 1982 - 1984

1981 A's summer school for the Performing Arts, New York Announcer/Master of Ceremonies, "Regines Halloween Party", Regines, New York

1980 Guest Lecturer, National Center for Afro American Artists, Roxberry Mass. Panelist, Franklin Furnace, New York

Panelist, The Dynamics of Collaboration, Artists Talk on Art, New York

1979 It's A Performance Art Workshop, producer, A's, New York

1975/71 Artist in Residence, Public School 161, New York

1971/69 Artist in Residence, Public School 1, New York

1969/67 Artist in Residence, Experimental Piaget Program, New York

MEMBERSHIPS AND ORGANIZATIONAL AFFILIATIONS

American Society for Composers, Authors and Publishers

Broadcast Music Industry

American Association for the Advancement of Science

Artists and Writers Copyrights Committee 
CATALOGUES

1987

"AEIOU", Europalia 87 Osterreich, Belgique

1986 "Arleen Schloss: A. E. Bla Bla Bla", by Peter Frank, Ars Electronica Festival for Art, Technology and Society, Linz Austria

1985 "Alternating Currents", Athens Printing Co., Alternative Museum, New York

"Arts, Arno", Artibus Sacrum, Arnheim, The Netherlands

.84 "Videonale, 84", Petra Unnutzer, Bonn, W. Germany

1983 "Blitzkunst", ed. Ginny Lloyd, verlag Kretschmer and Grossman, Frankfurt, West Germany

1982 "Ressegna internazionale donne autrefici di cinema e video", il Bagatto, Roma, Italy

1981 "Europaische Videotheken", Stadtische Galerie im Lenbachhaus, Munich, West Germany

"Arte Postal", XVI Bienal De Sao Paulo, Brasil, Dec.

1980 "The Office", Spring \& West Broadway, New York

1978 "Artists Books, USA", ed. Peter Frank, Martha Wilson, Independent Curators Inc.

"Artwords and Bookworks", Joan Hugo, Judith Hoffberg, Los Angeles Institute of Contemporary Art, California

1975 "Abstraction Alive and Well", State University College, Potsdam, New York

1974 "American Federation on the Arts", Green, Wilder, Circulation Exhibit

1973 "Tenth Anniversary Exhibition", Carlus Dyer, The Aldrich Museum of Contemporary Art Ridgefield, Connecticut

1972 "New York Women Artists", Lawrence Alloway, State University of New York at Albany

"Contemporary Reflections", Aldrich Museum of Contemporary Art, Ridgefield, Connecticut

?971 "8 X 10", folio series. 
ARTICLES AND PUBLICATIONS BY THE ARTIST

1989 "A Chance Intervlew with John Cage", Splash Magazine, September, New York

1987 "A Cez", JAA \#7, New York

1986 "Dear Theory", Ars Electronica Katalog, Linz, Austria

1985 "No Se No", The Act, New York

1984 "Voices through 1984", Makkom Katalog, Amsterdam

1983 "How She Sees It-by Her", JAA \#6, New York

1982 "How She Sees It", High Performance Magazine, Los Angeles, CA

1981 "The Live Performance Story from A to Z", High Performance Magazine, May, Los Angeles, California

"A's Poster Magazine", New York

1980 "Archeology of the 80's", The Village Voice, July, New York

1978 "Alphabet", New Wilderness Letter, September, New York

PUBLICATIONS

1985 "Alles und noch viel mehr-Das Poetische ABC", von G.J. Lischka, Autoren und Benteli Verlag Bem, printed in Switzerland

1984 "The Art of Performance (a critical anthology)", Ed. Gregory Battcock/ Robert Nickas, published by E.P. Dutton, Inc., New York

1982 "New York Art Review", Ed. Les Krantz, published by American References, Inc. ed.\#2 1982/ ed. \#3 1986/ ed. \#4 1990

"New York Art Guide", Ed. Jane Gardner, published by Art Guide Productions, London

1980 "Text-Sound Texts", Ed. Richard Kostelantz, published by William Morrow and Company, Inc., New York

1979 "Anderson and Archers Soho, The Essential Guide to Art and Life In Lower Manhattan" authors Alexandra Anderson, B. J. Archer, published by Simon and Shuster

1978 "CopyArt", Ed. Patrick Firpo, Lester Alexander, Claudia Katayanagi, Steve Ditlea, published by Richard Marek Press, New York

"Weaving, A Handbook of the Fiber Arts", second edition, Ed. Shirley E. Held, published by Holt, Rinehart and Winston

1976 "6th Assembling", Ed. Henry Korn, Richard Kostelantz, Mike Metz, published by Assembling Press, New York

"hor'zon", author, Skye Vermont, published by Anillusion Press, New York

"Who's Who in American Art" 
AUDIO PUBLICATIONS

1987

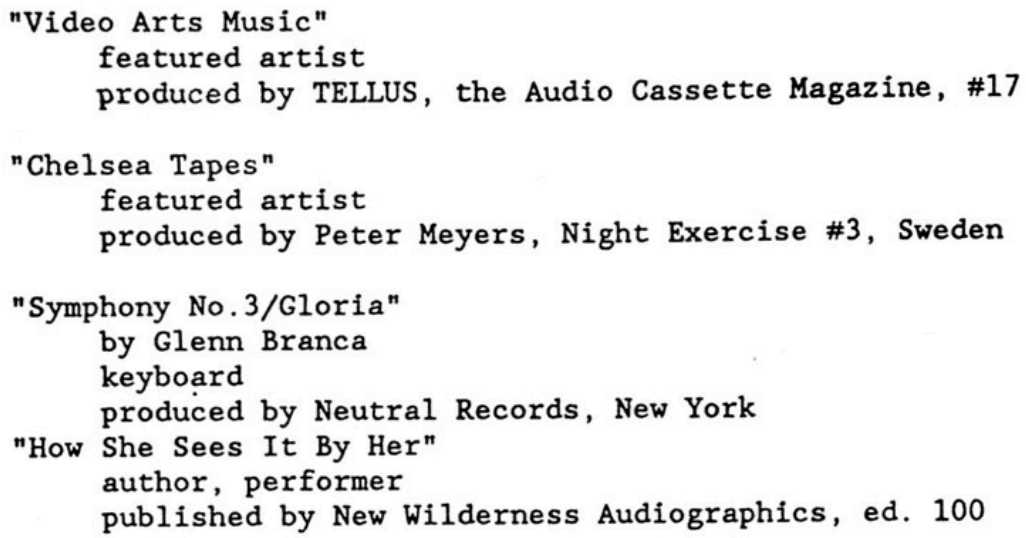

"Symphony No.3/Gloria"

by Glenn Branca

keyboard

produced by Neutral Records, New York

"How She Sees It By Her"

author, performer

published by New Wilderness Audiographics, ed. 100

1983

1982

"Live to Air"

featured artist

produced by Audio Arts at Tate Gallery, London

"JAA \#5"

featured artist

produced by Barbara Ess/Glenn Branca, New York

1979 "Mag Magazine"

featured artist

produced by Modern Art Galeria, Vienna, Austria

"Audio Arts"

featured artist

produced by William Furlong, London, England

"Humanic"

advertisement

Humanic Shoe co., Vienna, Austria 
CURATOR

1989 "Asian Heritage Month"

featured artists, Martin Wong, Shirin Neshat, Kazuko

Triplex Theatre Gallery,

Borough of Manhattan Community College, New York

1988 "10 Chinatown/Open Studio"

in collaboration with the Asian American Art Center

featured artists, Ken Hiratsuka, Alwin Eng

A Gallery, New York

1987 "Films on Mist"

featured artists, Tesse Hughes-Freeland, Angela Schier1, Ursula Purrer

A's Sculpture Garden, New York

"Francesca Llopis, works from Barcelona"

A Gallery, New York

1986 "Fire, Water, Stone, and Steel"

featured artists, Ray Kelly, Linus Corriagio, Paolo Buggiani

A's Sculpture Garden, New York

1985

"Asia"

featured artists, Mong Fay, Kyong Park, Toyo, Toshio Sasaki

A Gallery, New York

$1984 \quad$ Founded A Gallery

"The Friends Show"

in collaboration with No Se No

featured artists, Andy Warhol, Joseph Beuys, Ray Johnson,

Karen Finley

A Gallery, New York

1982-80 "Video/Film Series"

featured artists, Paul Nichols, Mike Bidlo, Anne Barbe Kau $A^{\prime}$, New York 


\section{Appendix C: A's Posters}

The Museum of Modern Art Librery

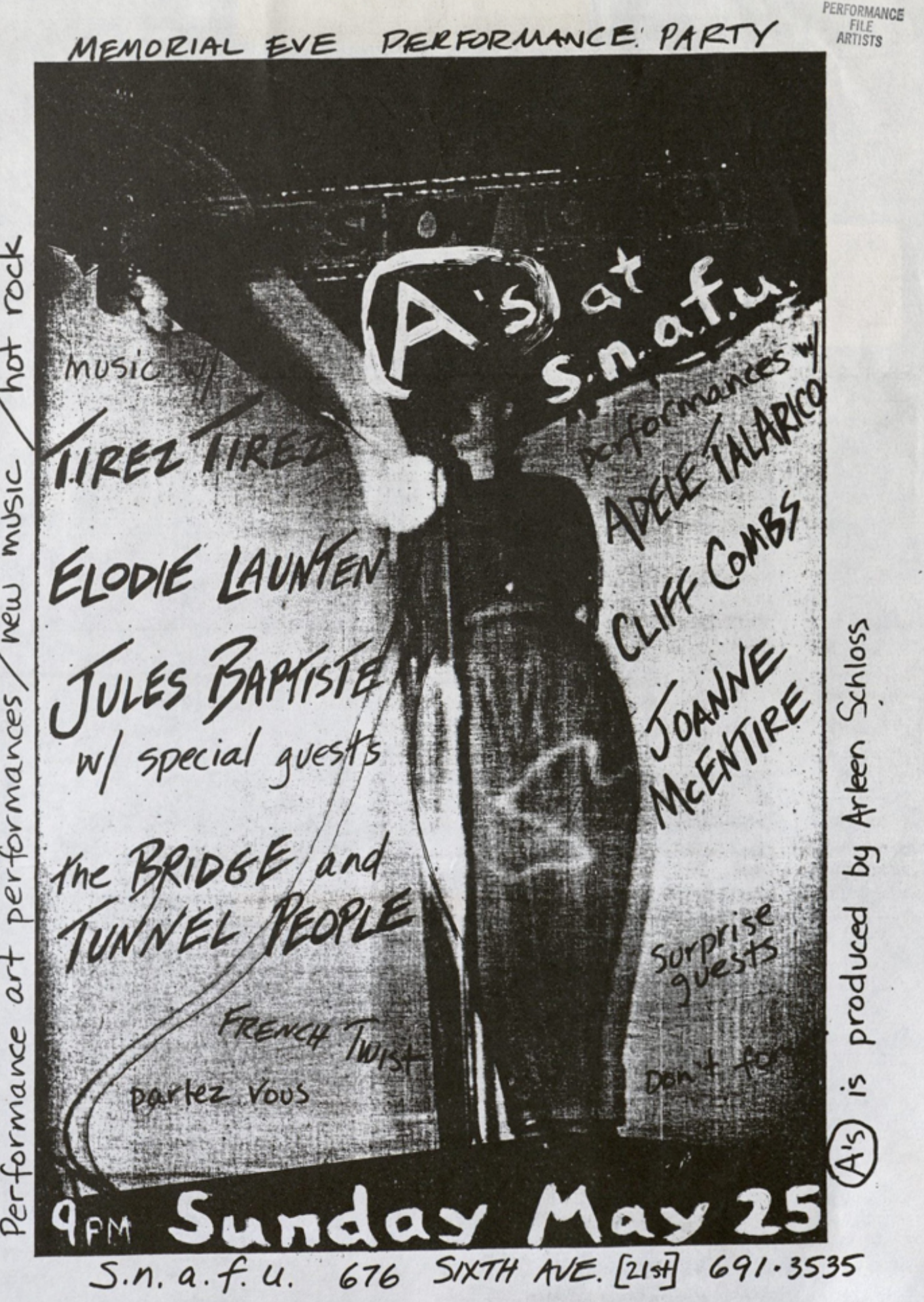


1980

$\$$

62 


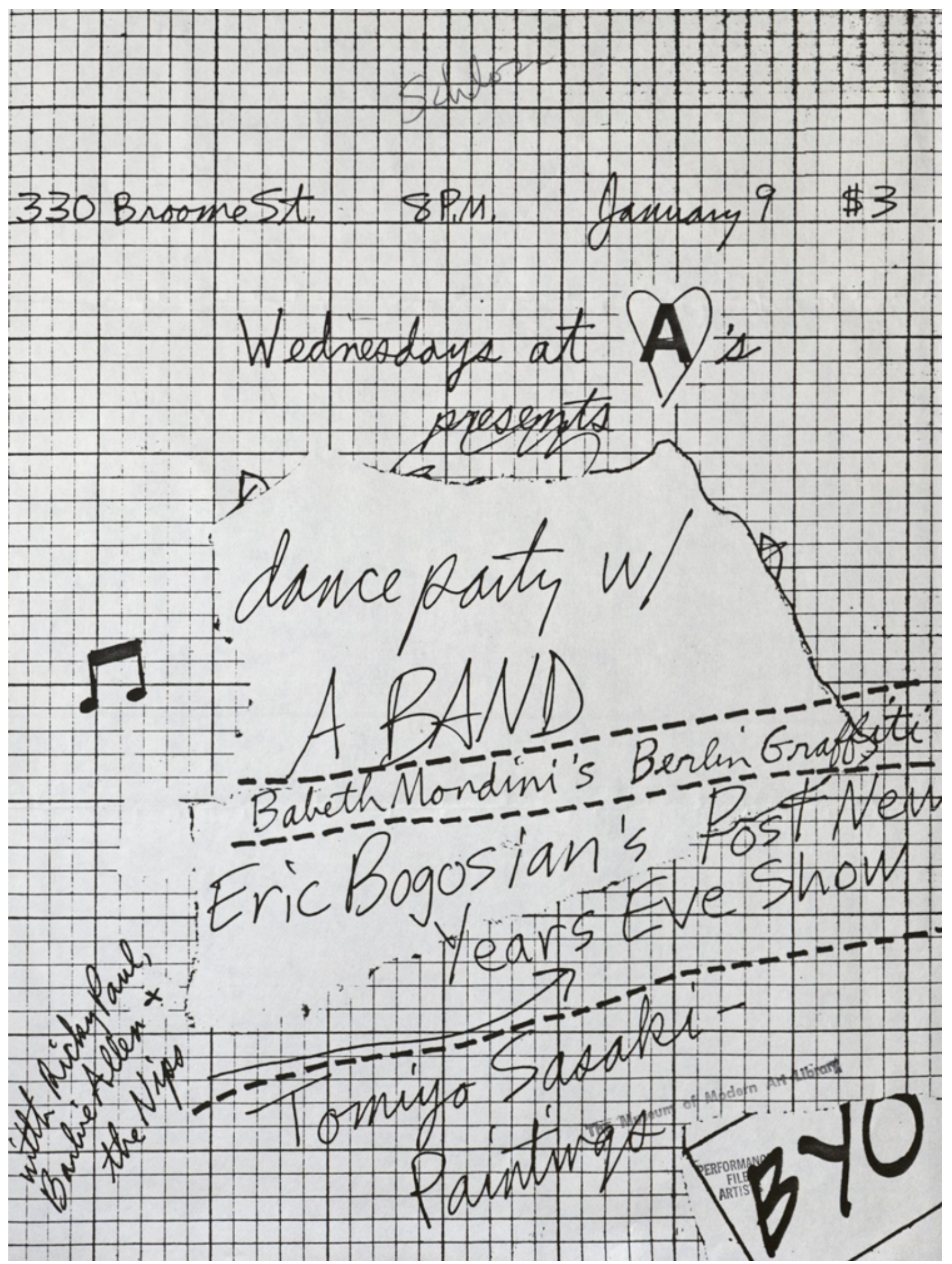




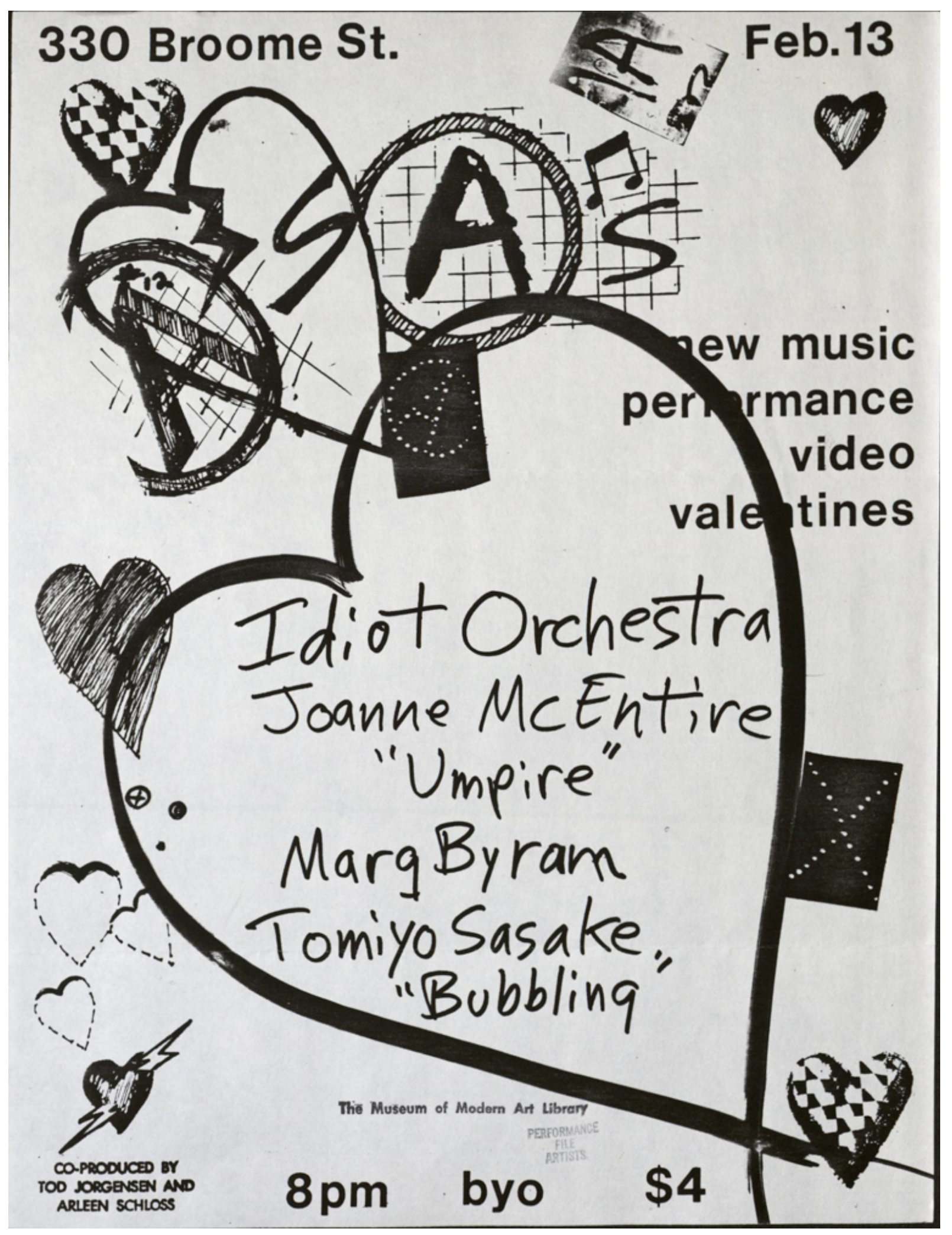




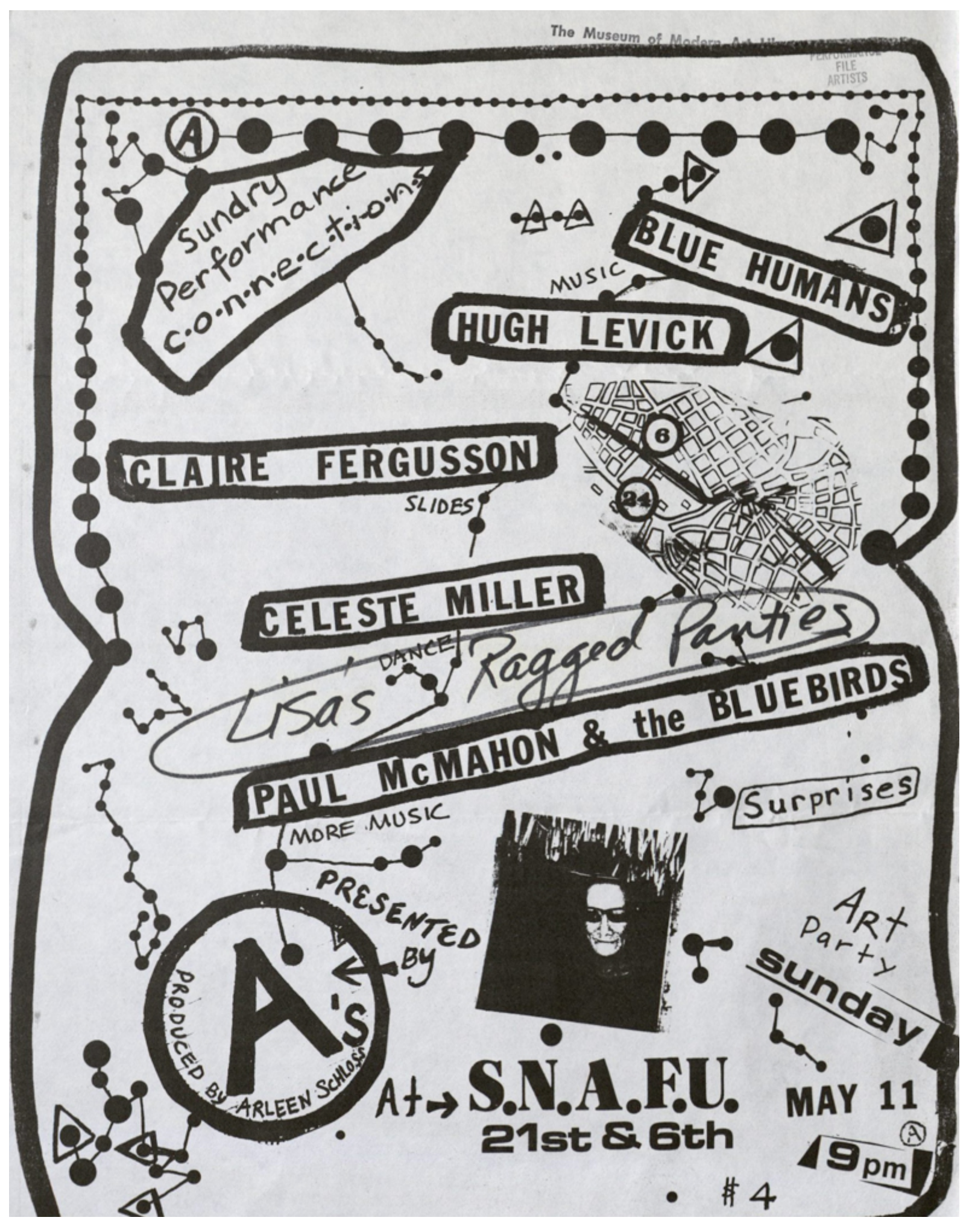




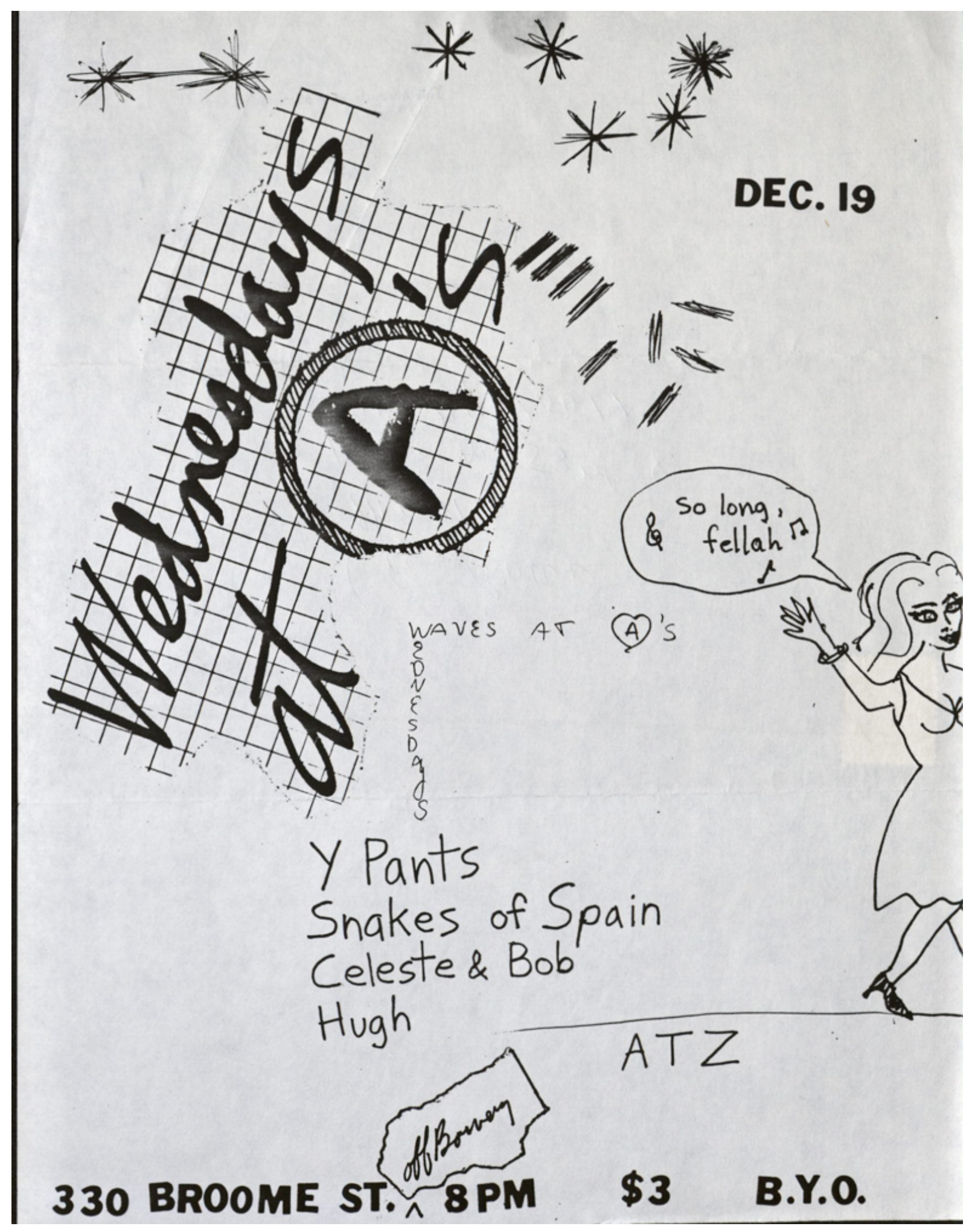




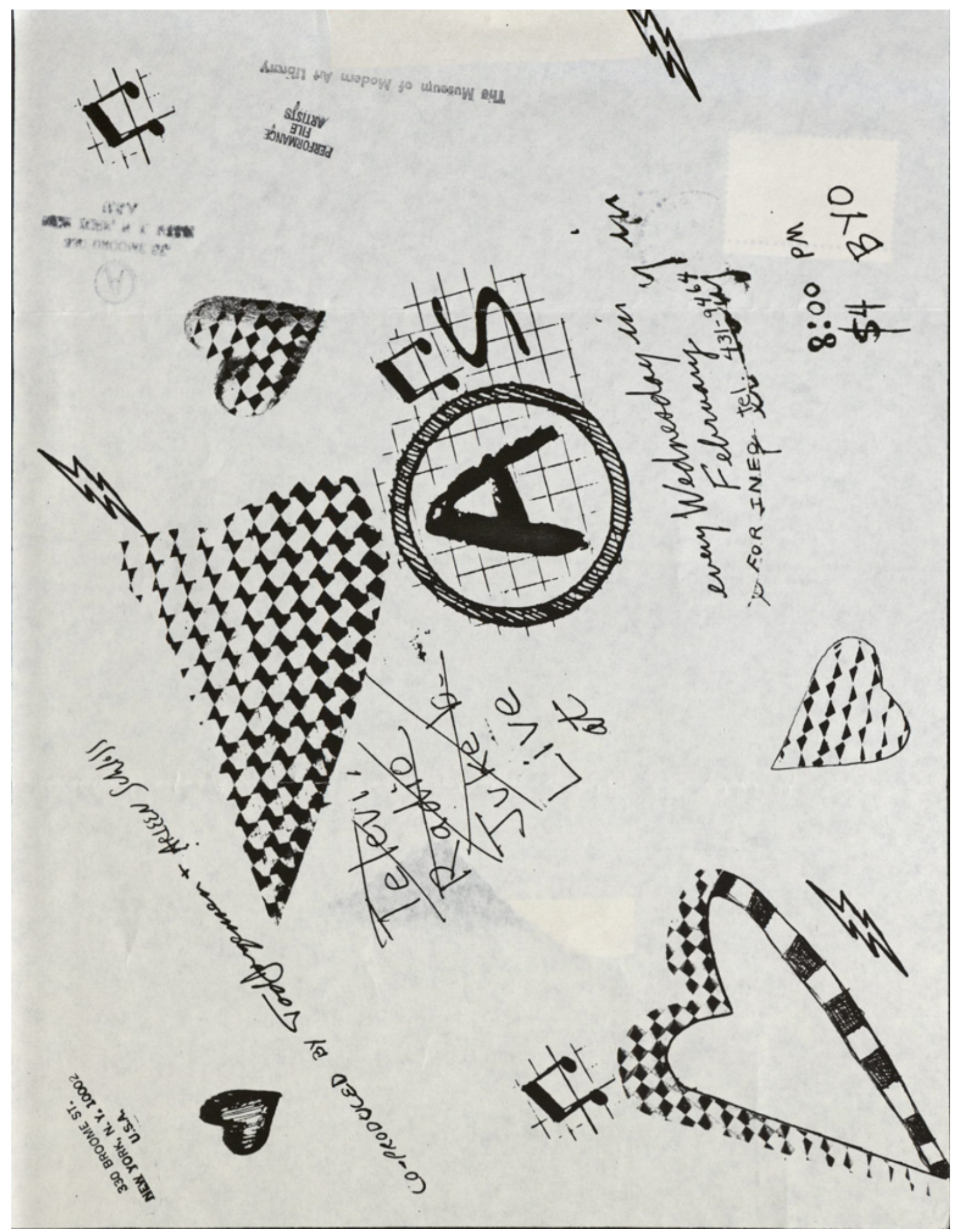




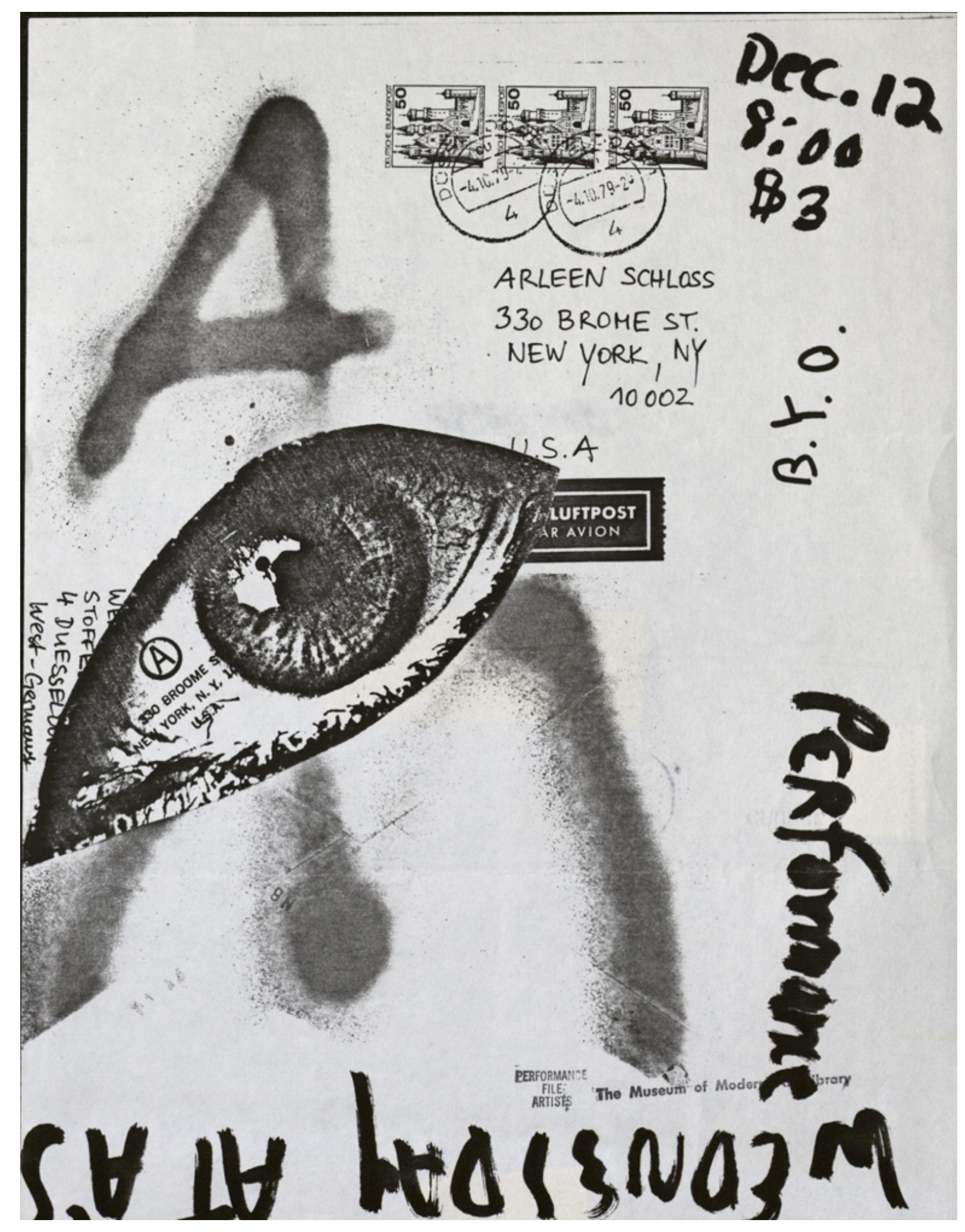




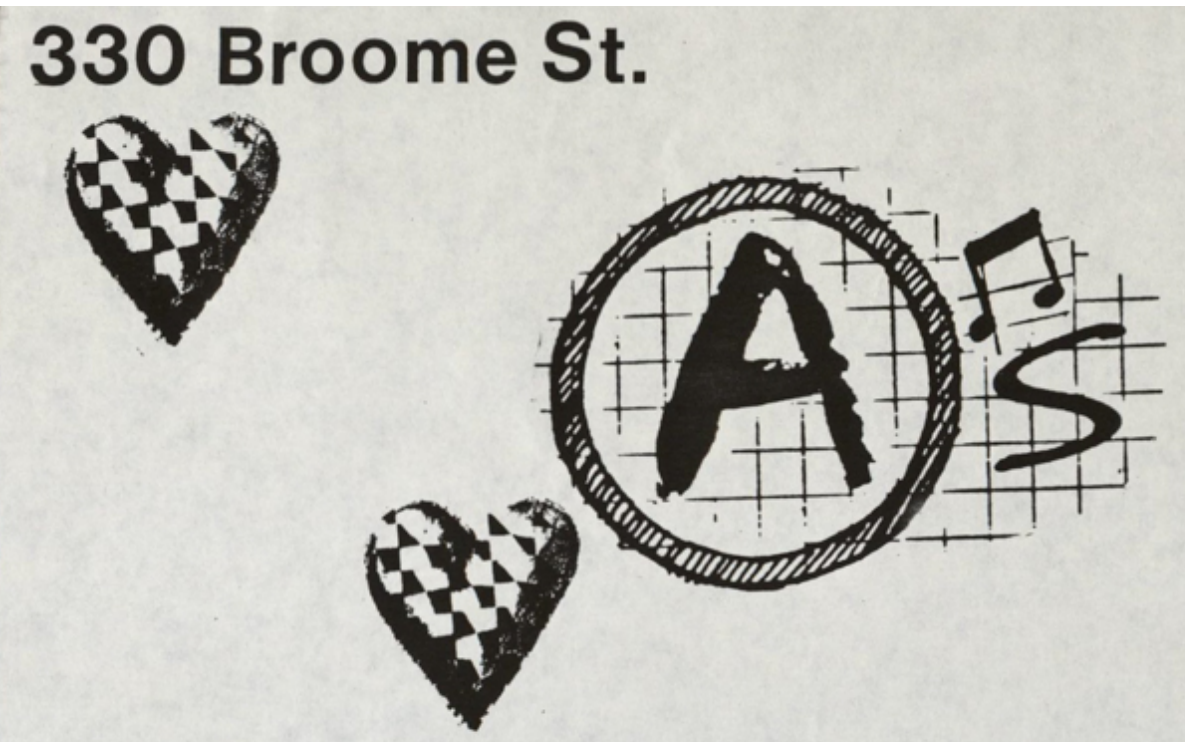

Feb. 6

Monad

$\mathrm{C}^{2}$

Robert L. Sanders

new music performance video film sax Mary Jane Leach \& Maureen Nappy Hugh Levick \& Alan Groubard
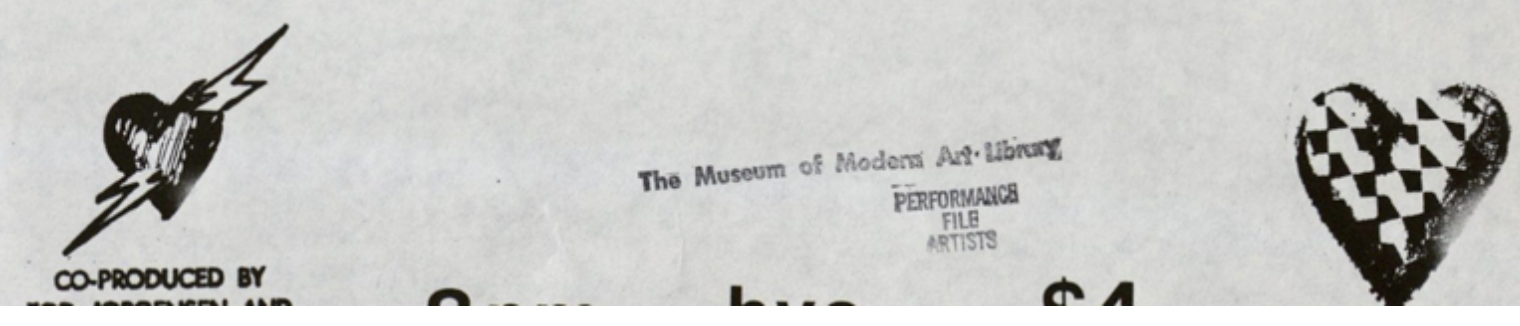


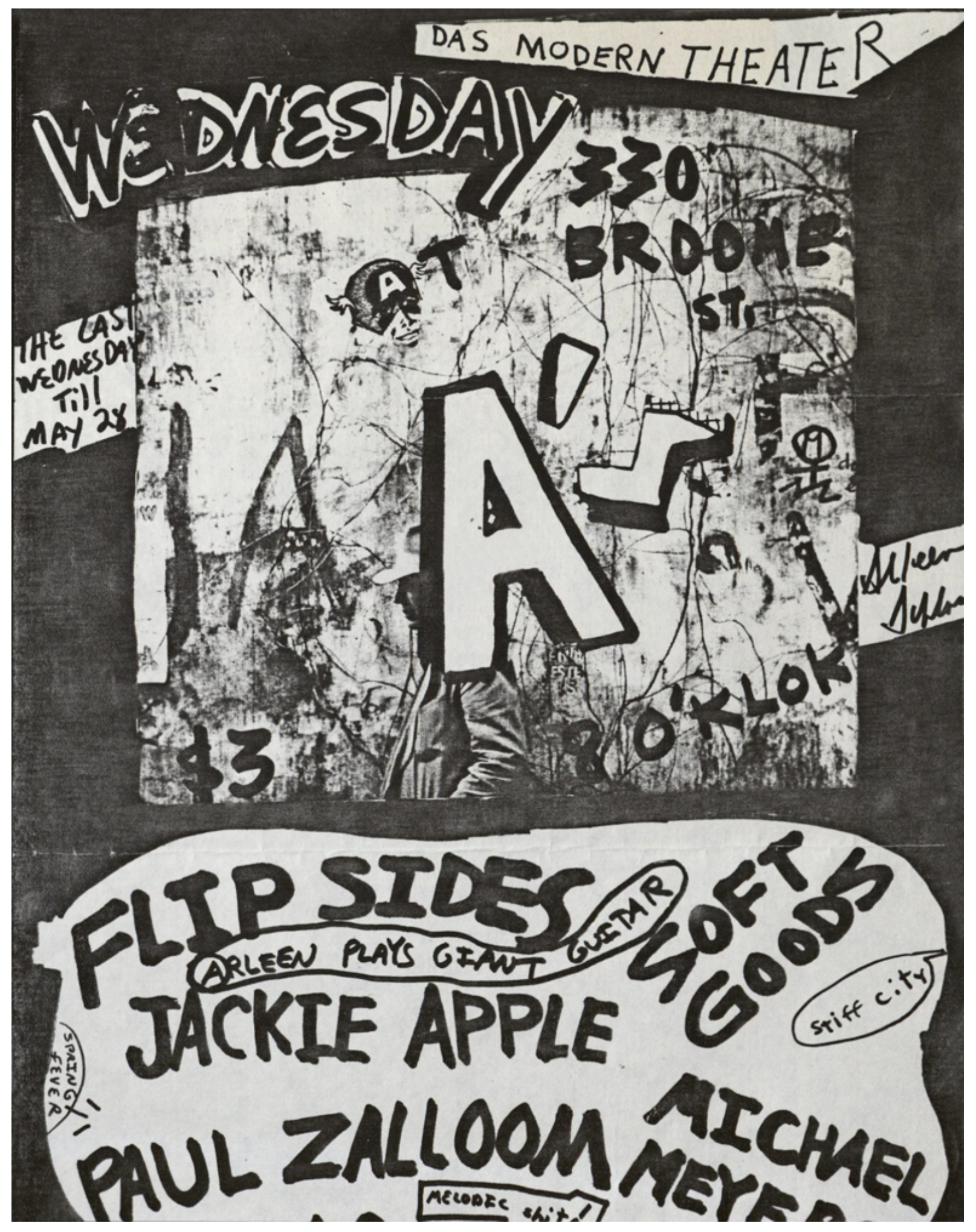




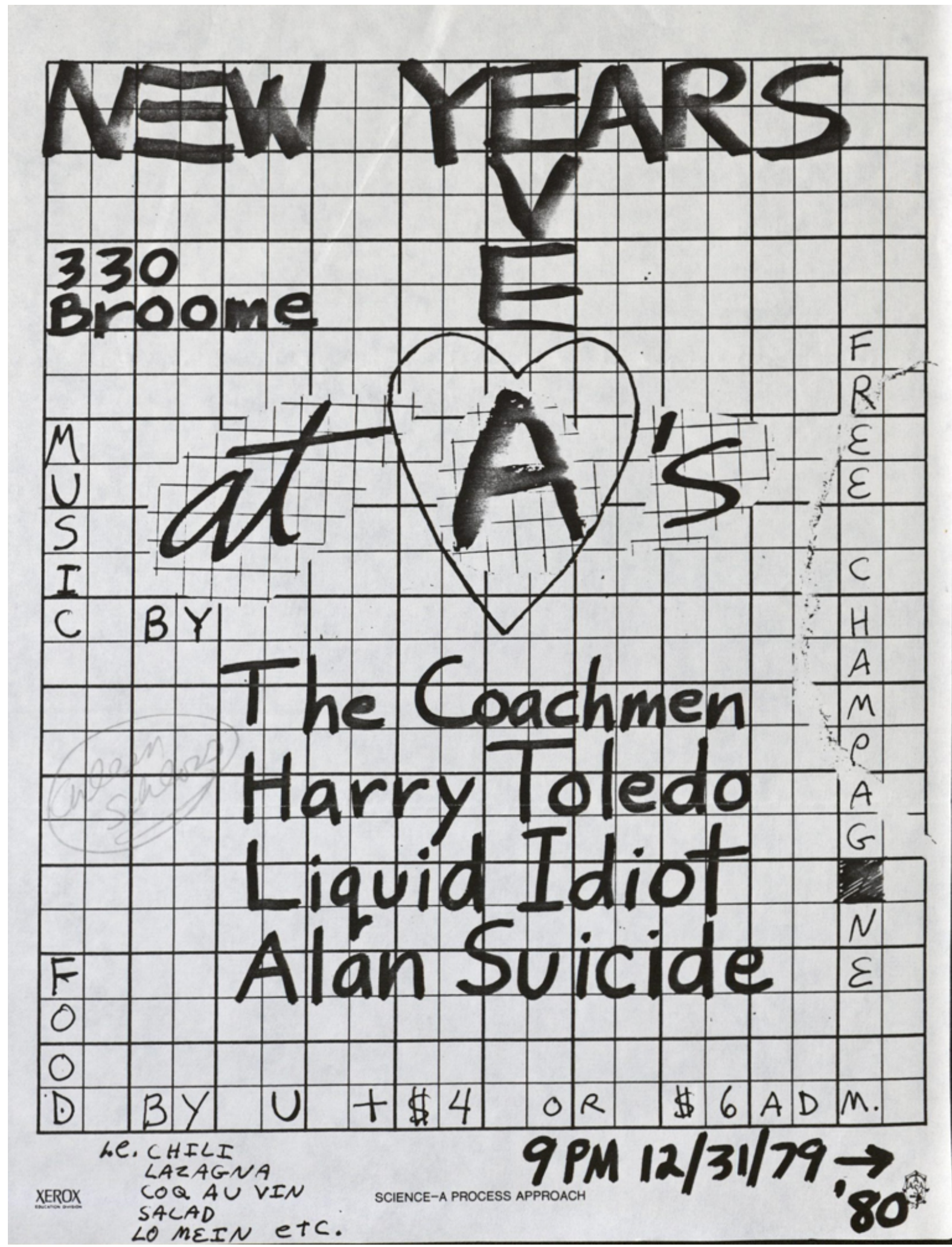

71 


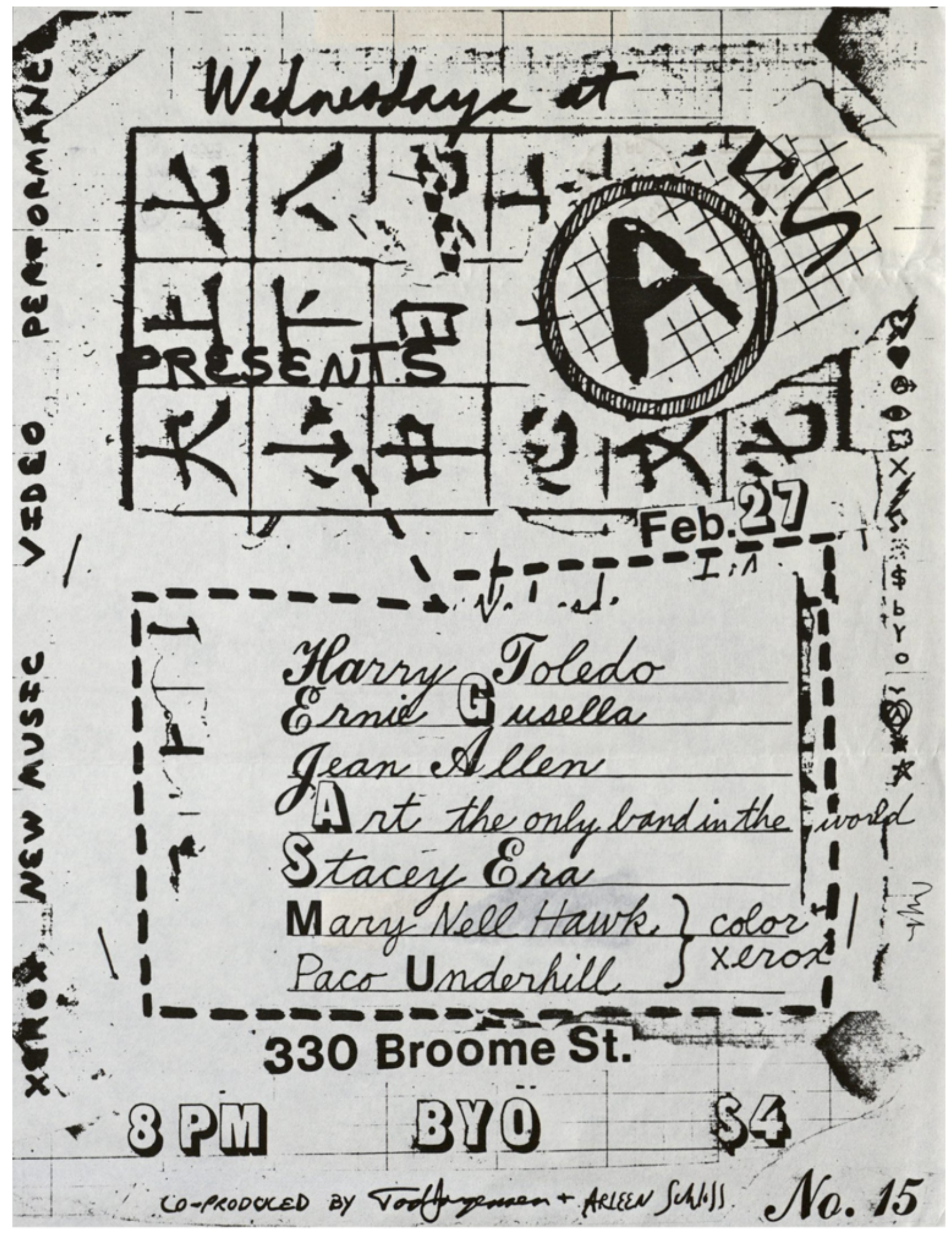




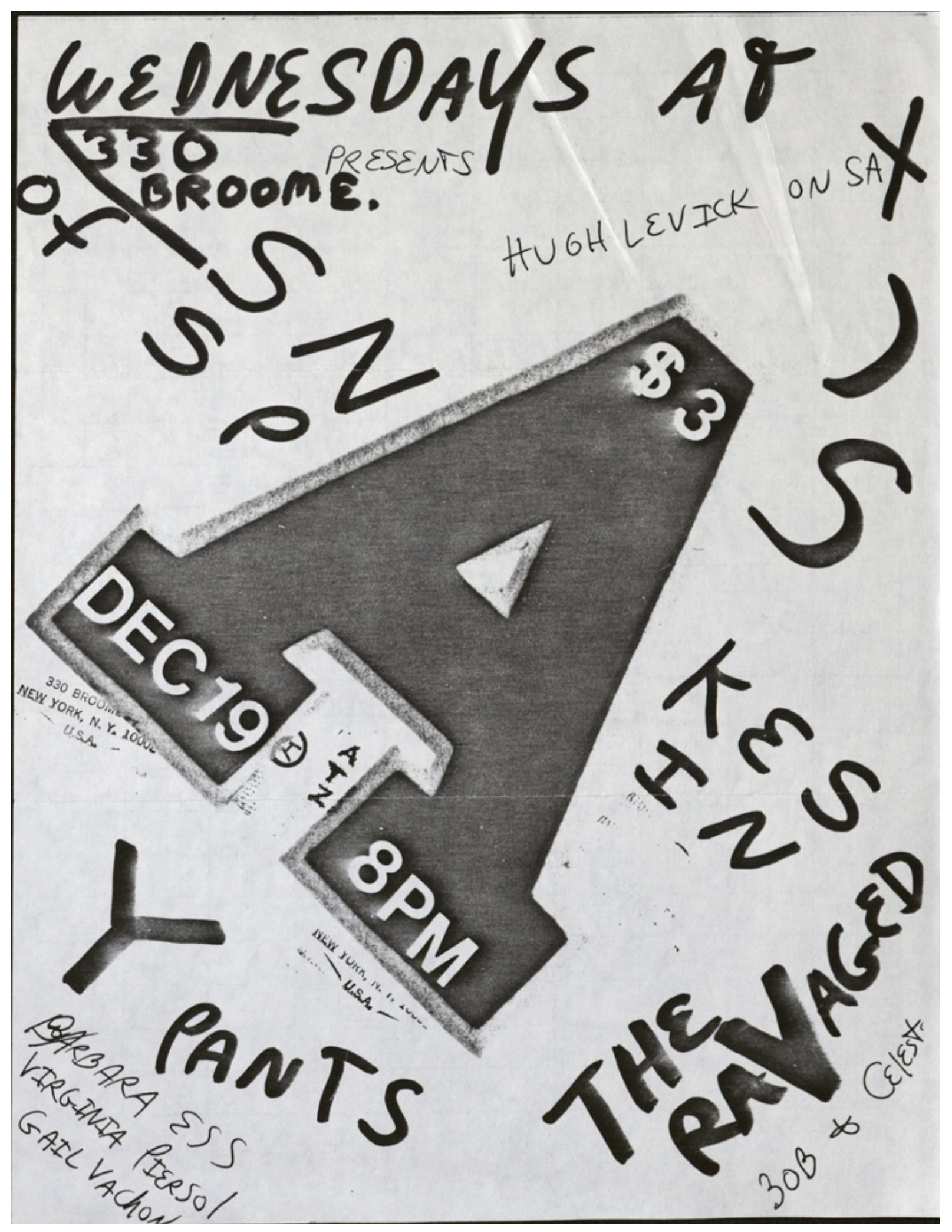




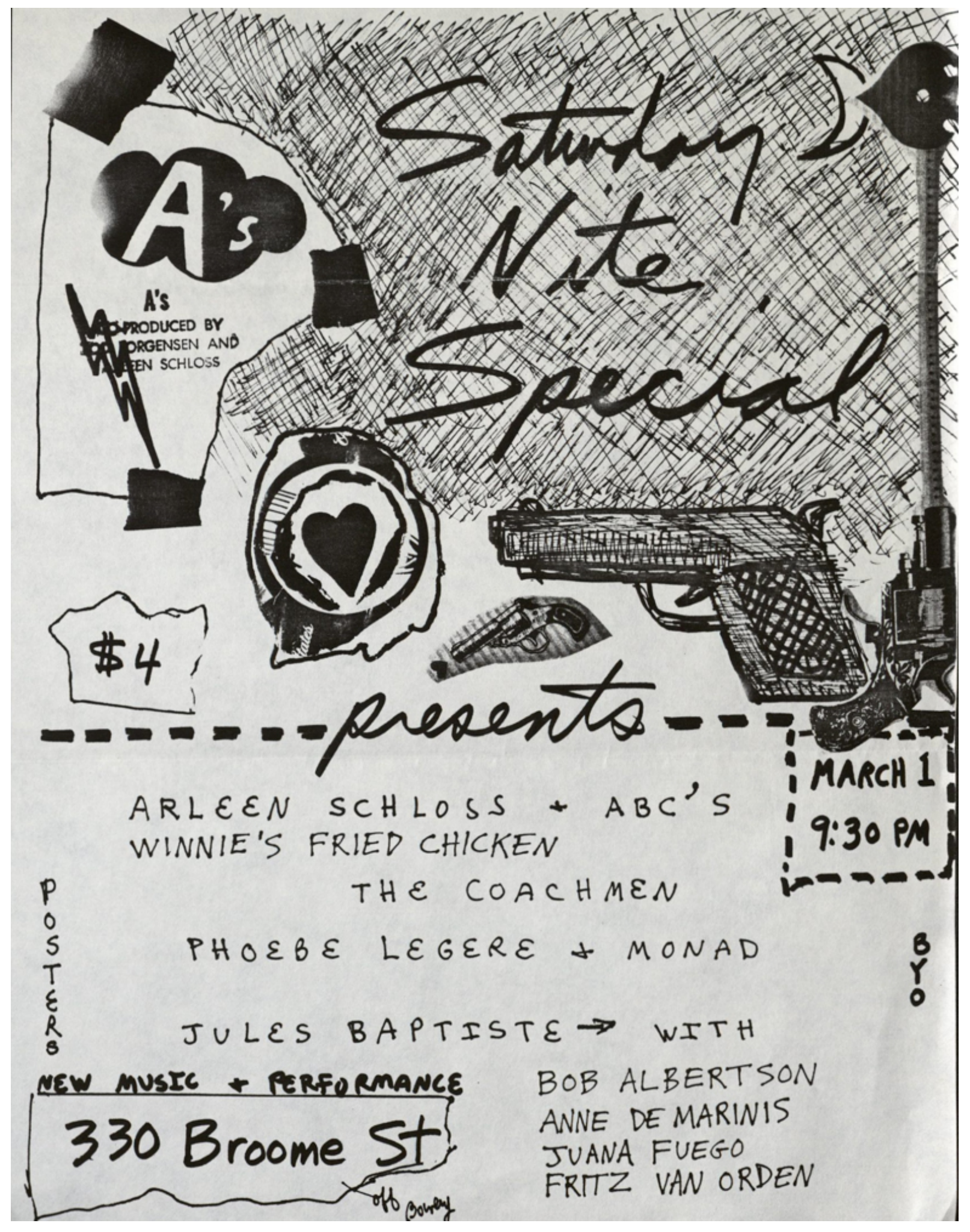




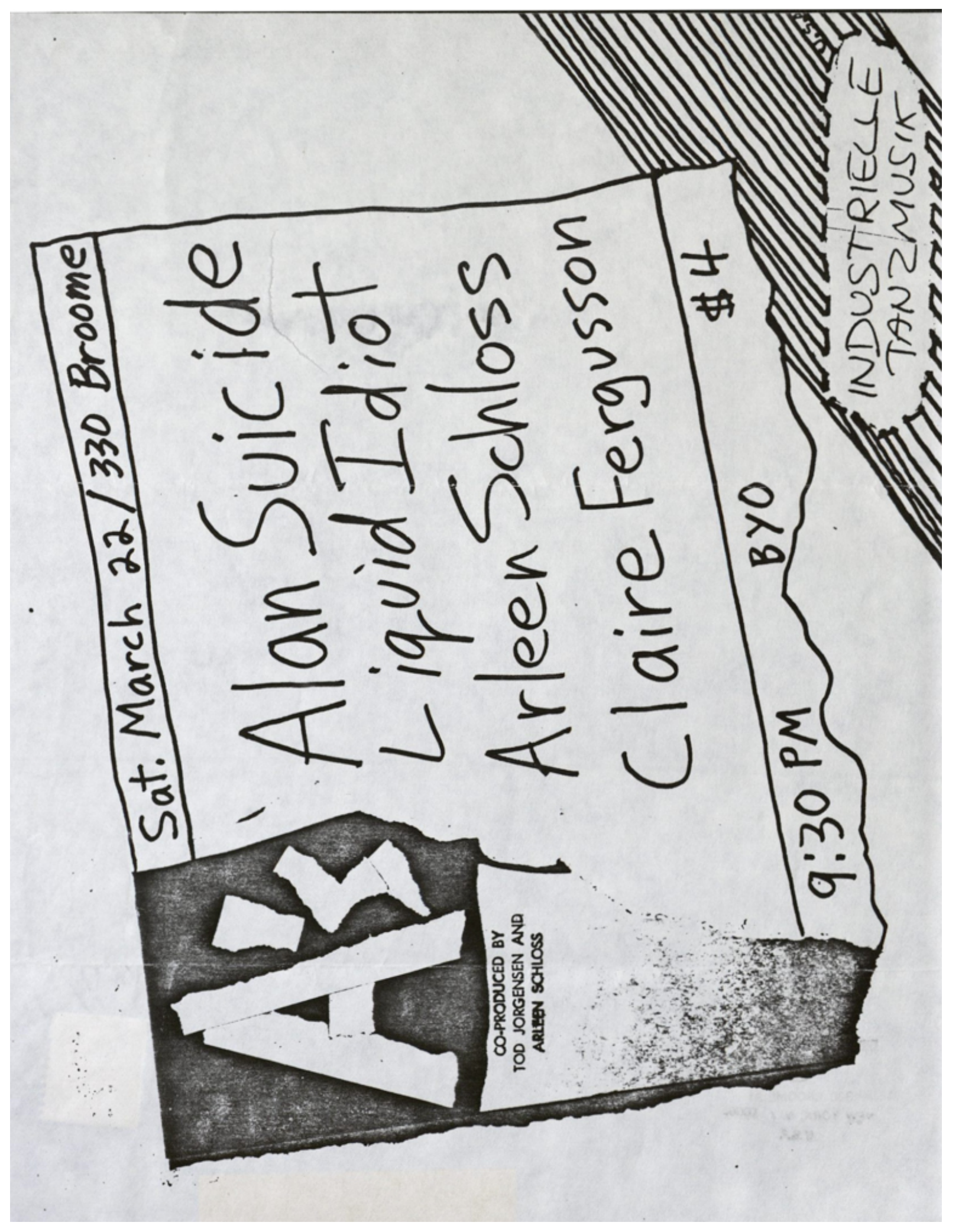


Wednesday

March 19

330 Broom St.

parents:

$8 P M{ }_{B 3}^{B Y O}$

Rudolph GreyThe Bluettumans

Robert Rutman- U.S. Steel Cello Ensemble

Claire Fergusson

Judy Rif Ka - Flags

Civil Defense

Rolf Borjlind

COPRODUCED BY
TOD JORGENSEN AND
ARLEEN SCHLOSS 


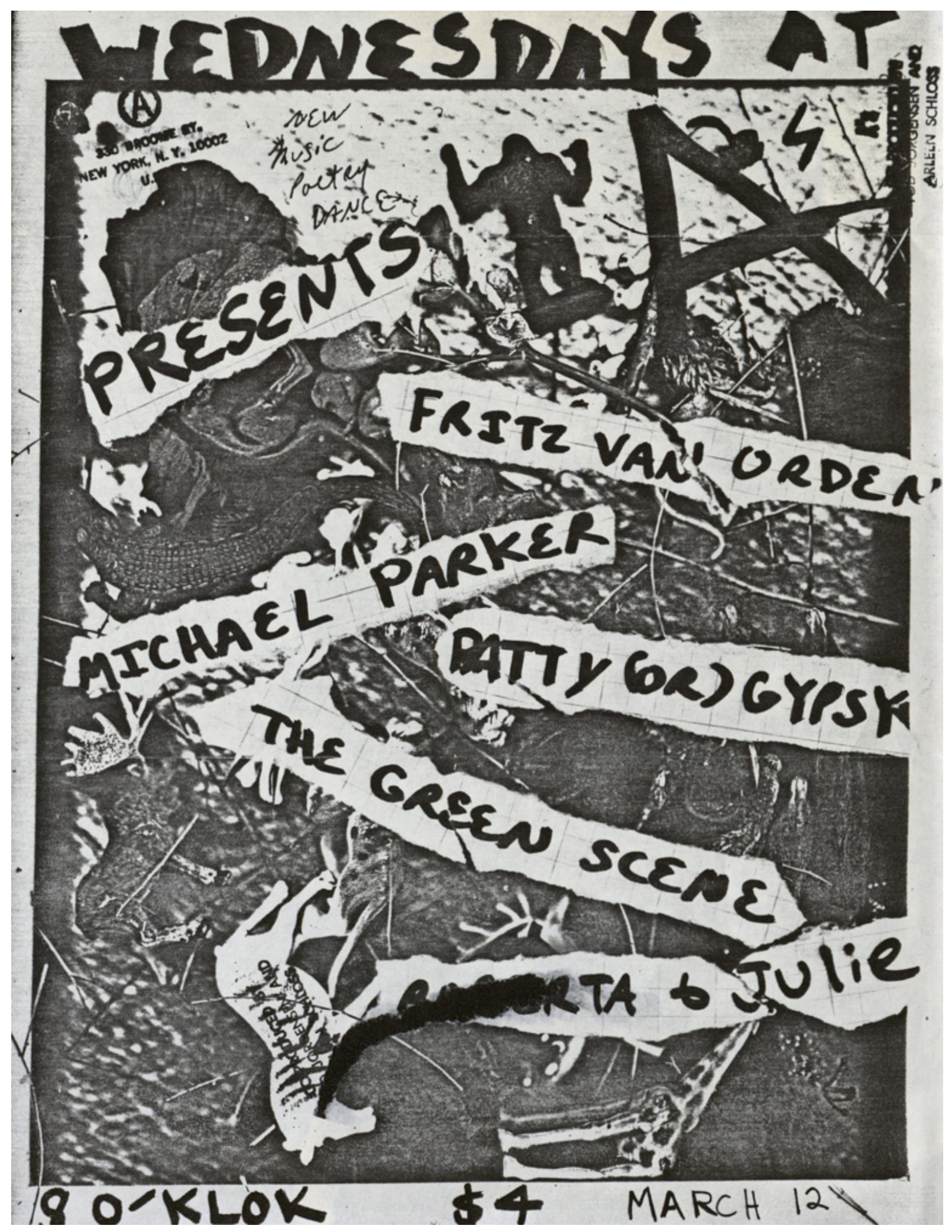




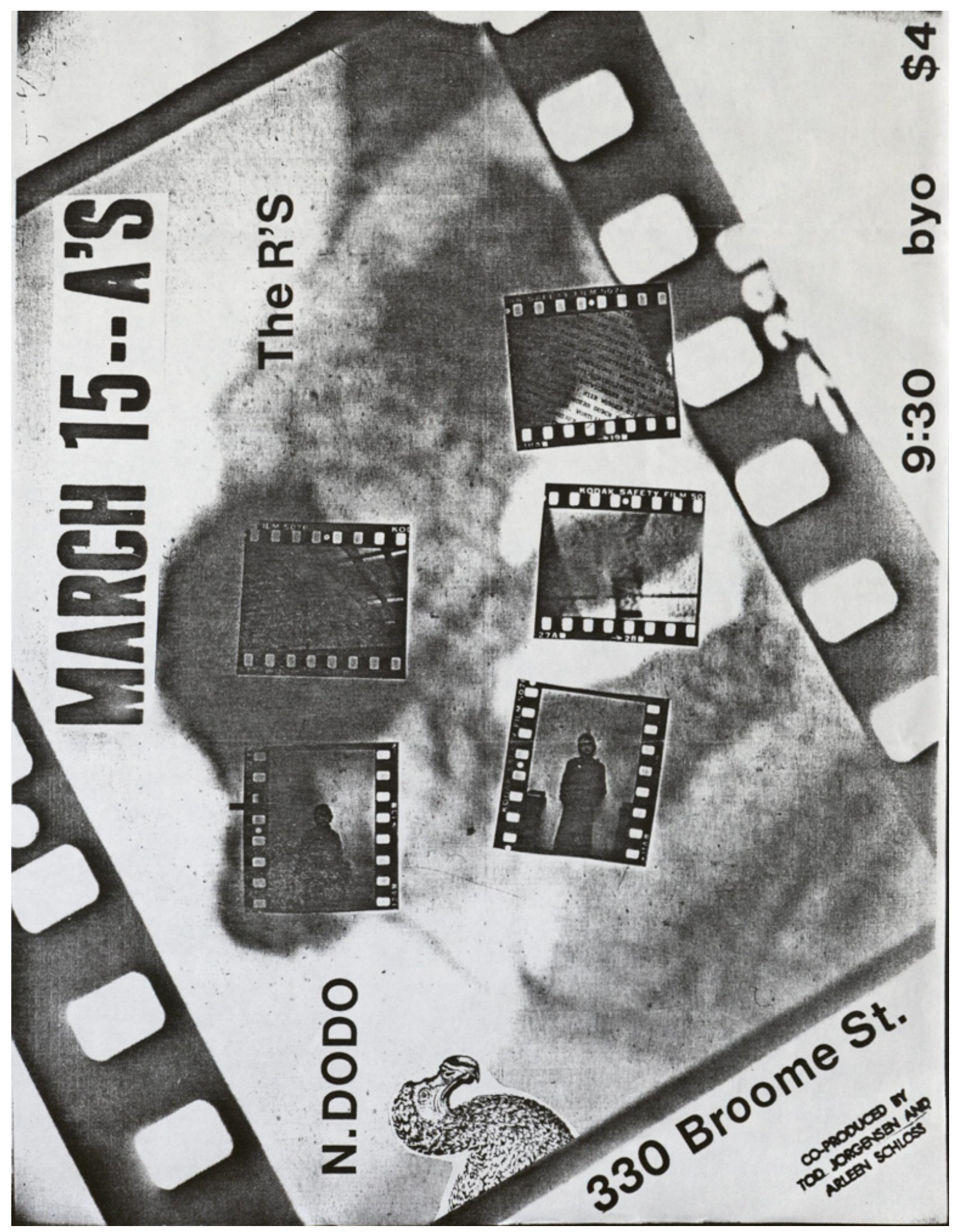




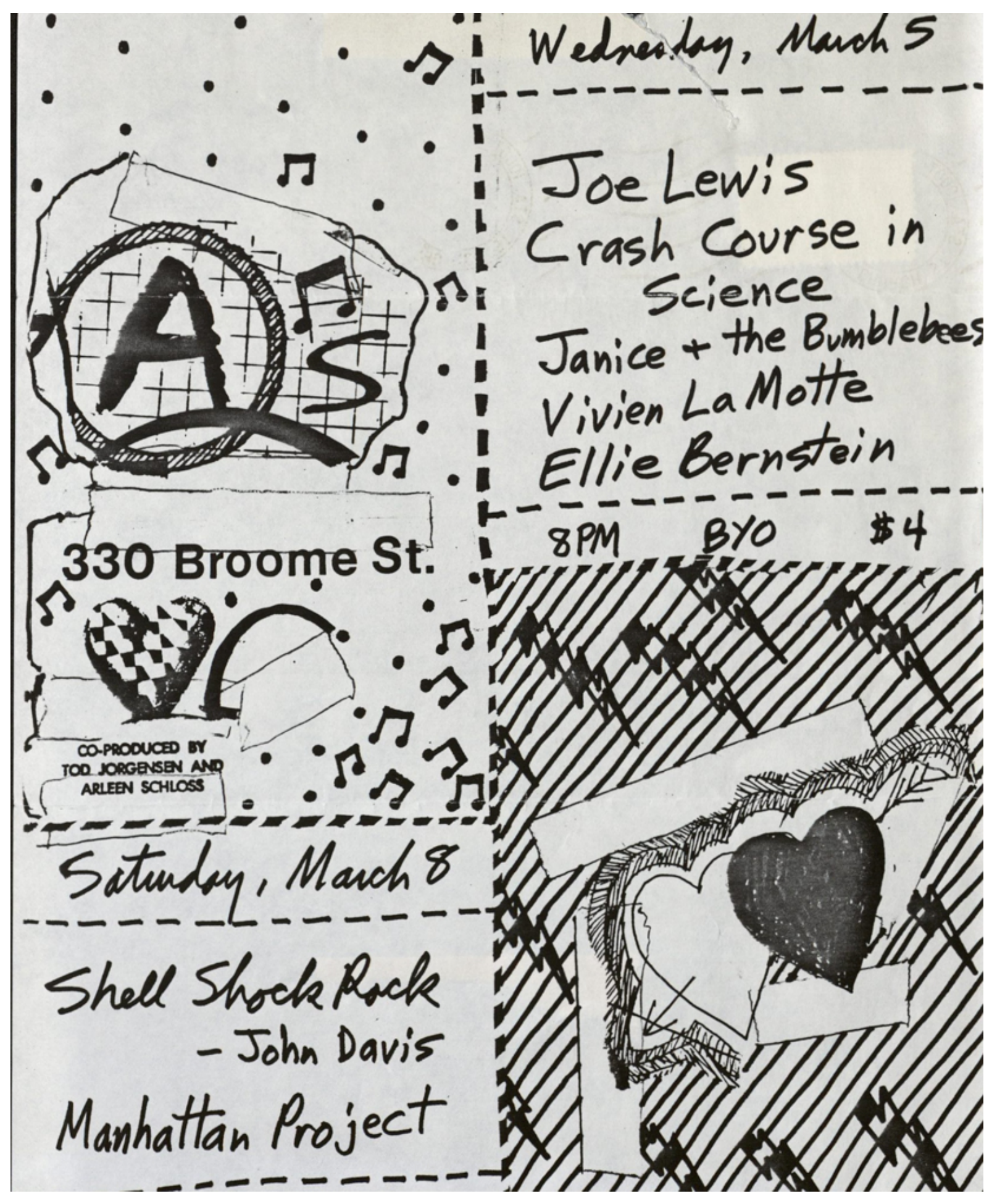

79 


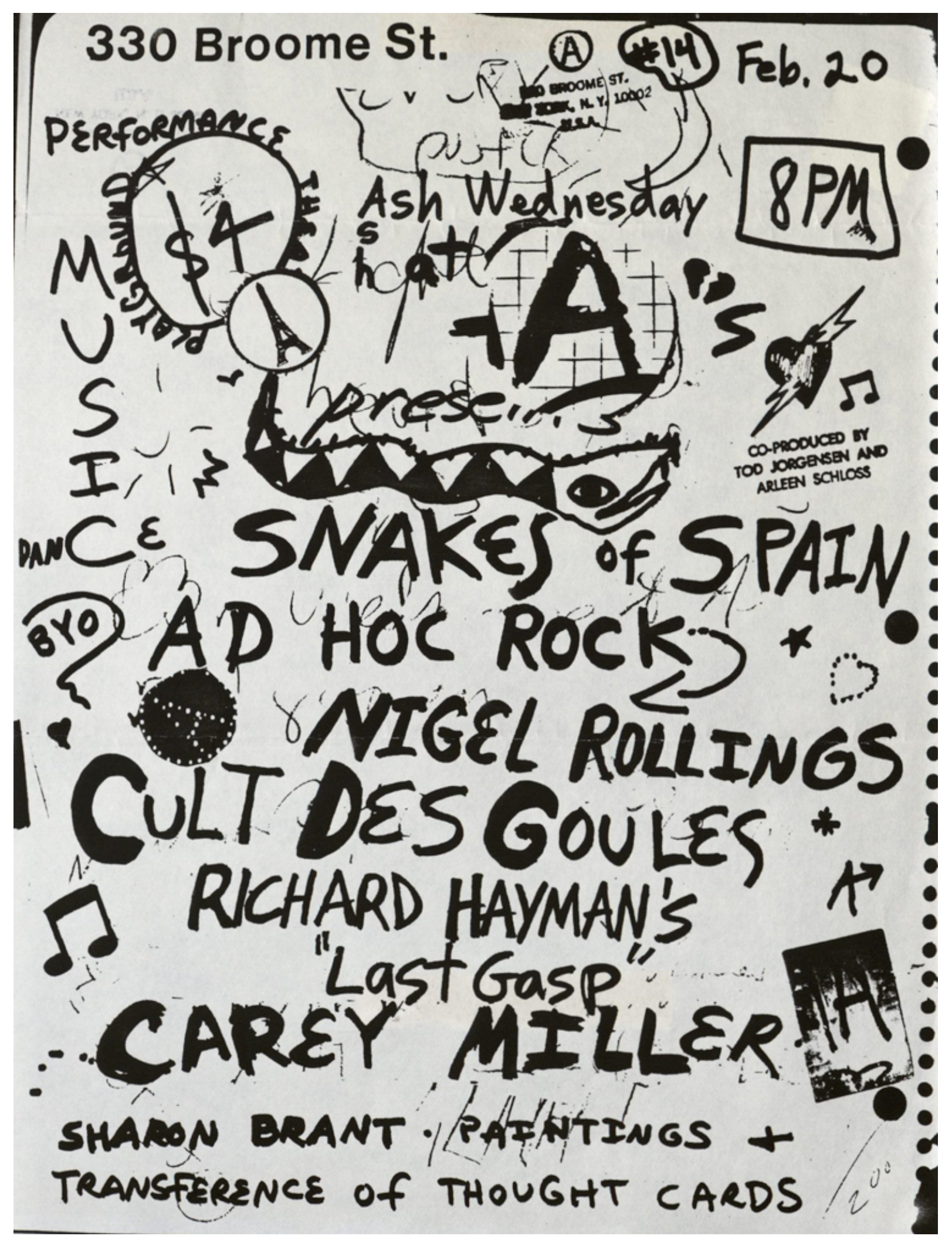




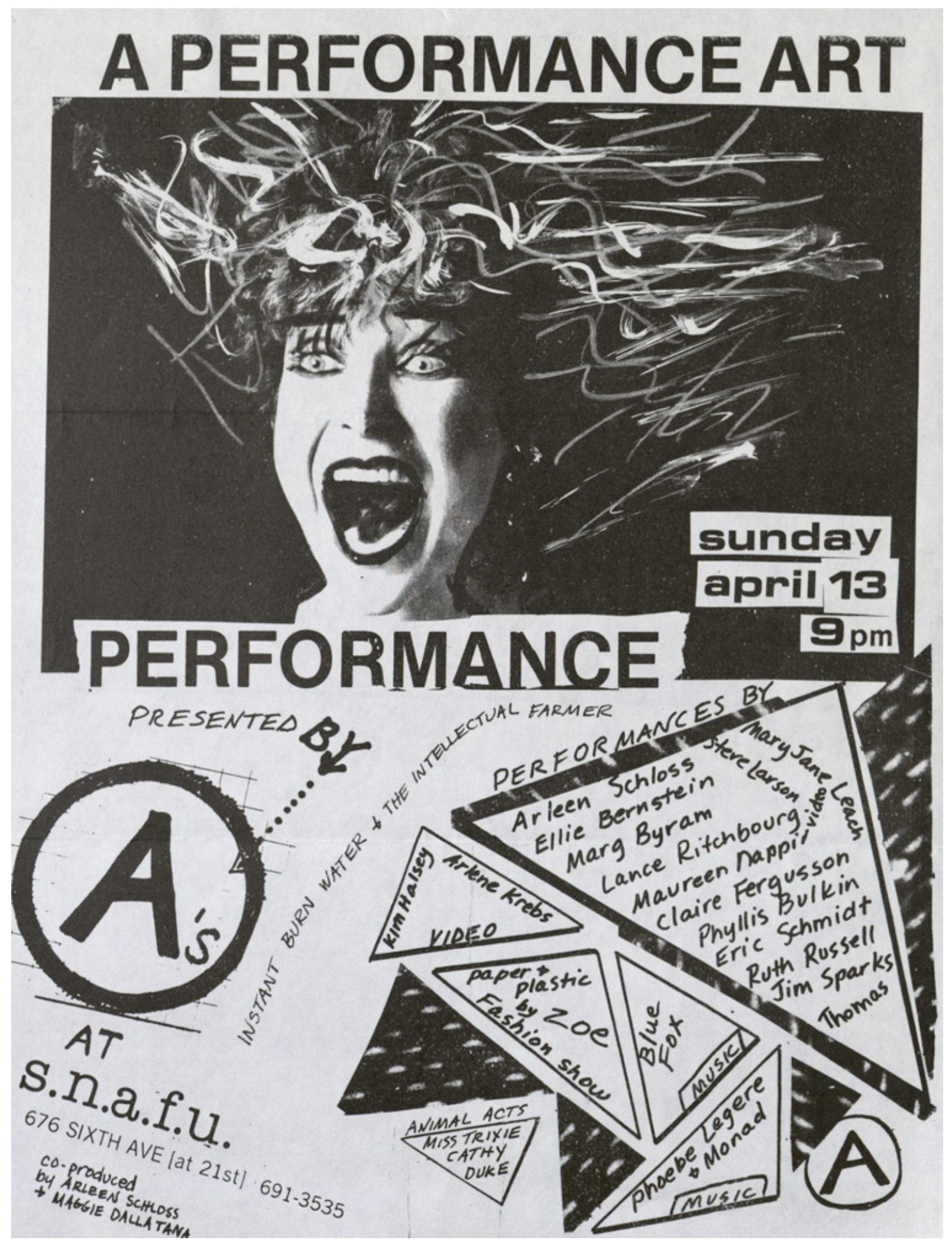




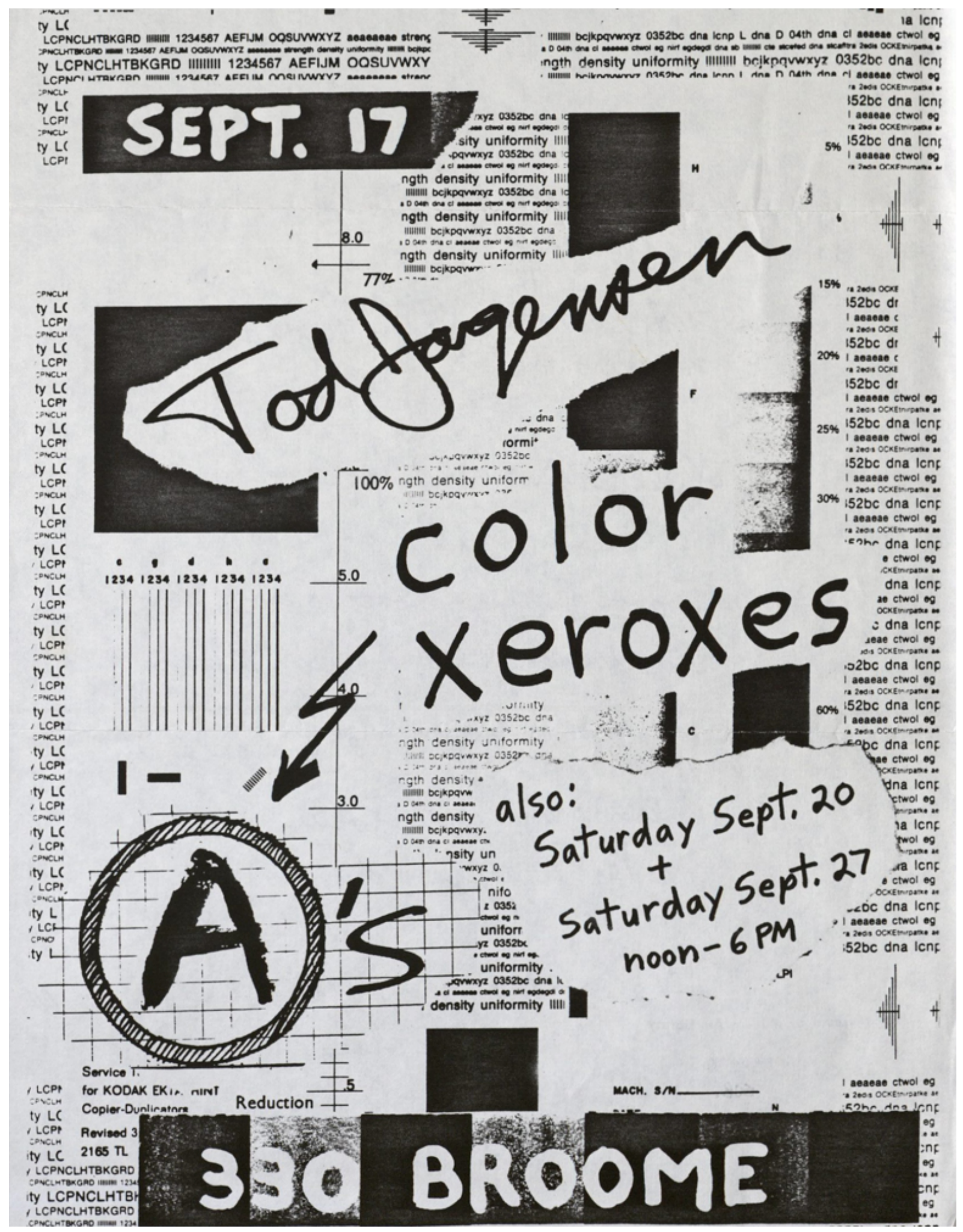




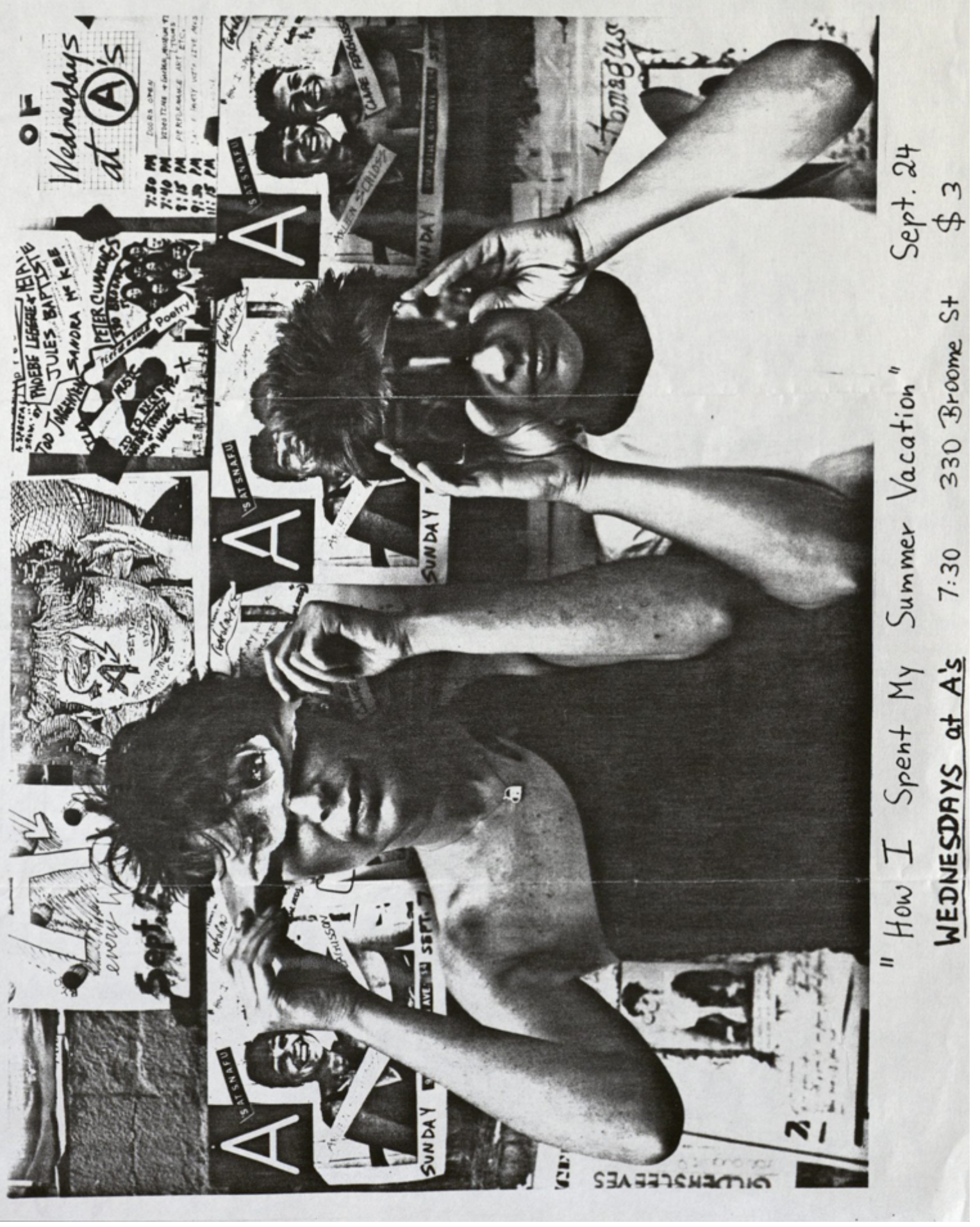


Appendix D: Catalogued Films and General Information

\begin{tabular}{|l|l|}
\hline Accession Number & $\mathbf{2 0 1 5 . 0 0 0 2 . 0 0 7 2}$ \\
\hline Title & [Untitled] \\
\hline Gauge & Super $\mathbf{8 m m}$ \\
\hline Date Code & $\mathbf{1 9 8 0}$ \\
\hline Colour & Colour \\
\hline Film Polarity & Reversal \\
\hline Element & Camera Original \\
\hline Sound & Magnetic Stripe \\
\hline FPS & Unknown \\
\hline Aspect Ratio & $\mathbf{1 : 3 3 : 1}$ \\
\hline Length & $\mathbf{5 0 . 0}$ ft. \\
\hline Film Wind & B Wind \\
\hline $\begin{array}{l}\text { Stock } \\
\text { Manufacturer/Type }\end{array}$ & Eastman Kodak/ Ektachrome \\
\hline Base Type & Triacetate \\
\hline Splices & O \\
\hline Archival Status & Archival Element \\
\hline Overall Condition & Good \\
\hline
\end{tabular}

\begin{tabular}{|l|l|}
\hline Accession Number & $\mathbf{2 0 1 5 . 0 0 0 2 . 0 0 7 3}$ \\
\hline Title & {$[$ Untitled- Aug 81] } \\
\hline Gauge & Super 8mm \\
\hline Date Code & 1981 \\
\hline Colour & Colour \\
\hline Film Polarity & Reversal \\
\hline Element & Camera Original \\
\hline Sound & Magnetic Stripe \\
\hline FPS & Unknown \\
\hline Aspect Ratio & $\mathbf{1 : 3 3 : 1}$ \\
\hline Length & $\mathbf{5 0 . 0} \mathrm{ft}$. \\
\hline Film Wind & B Wind \\
\hline $\begin{array}{l}\text { Stock } \\
\text { Manufacturer/Type }\end{array}$ & Eastman Kodak/ Ektachrome \\
\hline Base Type & Triacetate \\
\hline Splices & 0 \\
\hline Archival Status & Archival Element \\
\hline Overall Condition & Good \\
\hline
\end{tabular}




\begin{tabular}{|l|l|}
\hline Accession Number & $\mathbf{2 0 1 5 . 0 0 0 2 . 0 0 7 4}$ \\
\hline Title & {$[$ Brighton Beach] } \\
\hline Gauge & Super 8mm \\
\hline Date Code & Unknown \\
\hline Colour & Colour \\
\hline Film Polarity & Reversal \\
\hline Element & Camera Original \\
\hline Sound & Magnetic Stripe \\
\hline FPS & Unknown \\
\hline Aspect Ratio & $\mathbf{1 : 3 3 : 1}$ \\
\hline Length & $\mathbf{1 0 . 0}$ ft. \\
\hline Film Wind & Unknown \\
\hline $\begin{array}{l}\text { Stock } \\
\text { Manufacturer/Type }\end{array}$ & Eastman Kodak/ Ektachrome \\
\hline Base Type & Triacetate \\
\hline Splices & O \\
\hline Archival Status & Archival Element \\
\hline Overall Condition & Good \\
\hline
\end{tabular}

\begin{tabular}{|l|l|}
\hline Accession Number & 2015.0002 .0075 \\
\hline Title & {$[$ Untitled- July 26] } \\
\hline Gauge & Super 8mm \\
\hline Date Code & 1981 \\
\hline Colour & Colour \\
\hline Film Polarity & Reversal \\
\hline Element & Cut Original \\
\hline Sound & Magnetic Stripe \\
\hline FPS & Unknown \\
\hline Aspect Ratio & $\mathbf{1 : 3 3 : 1}$ \\
\hline Length & $\mathbf{5 0 . 0} \mathrm{ft}$. \\
\hline Film Wind & B Wind \\
\hline $\begin{array}{l}\text { Stock } \\
\text { Manufacturer/Type }\end{array}$ & Eastman Kodak/ Ektachrome \\
\hline Base Type & Triacetate \\
\hline Splices & 1 \\
\hline Archival Status & Archival Element \\
\hline Overall Condition & Good \\
\hline
\end{tabular}




\begin{tabular}{|l|l|}
\hline Accession Number & $\mathbf{2 0 1 5 . 0 0 0 2 . 0 0 7 6}$ \\
\hline Title & [Untitled- Dec 80] \\
\hline Gauge & Super 8mm \\
\hline Date Code & $\mathbf{1 9 8 0}$ \\
\hline Colour & Colour \\
\hline Film Polarity & Reversal \\
\hline Element & Camera Original \\
\hline Sound & Magnetic Stripe \\
\hline FPS & Unknown \\
\hline Aspect Ratio & $\mathbf{1 : 3 3 : 1}$ \\
\hline Length & $\mathbf{5 0 . 0}$ ft. \\
\hline Film Wind & B Wind \\
\hline $\begin{array}{l}\text { Stock } \\
\text { Manufacturer/Type }\end{array}$ & Eastman Kodak/ Ektachrome \\
\hline Base Type & Triacetate \\
\hline Splices & O \\
\hline Archival Status & Archival Element \\
\hline Overall Condition & Good \\
\hline
\end{tabular}

\begin{tabular}{|l|l|}
\hline Accession Number & $\mathbf{2 0 1 5 . 0 0 0 2 . 0 0 7 7}$ \\
\hline Title & {$[$ Friday Haircut] } \\
\hline Gauge & Super 8mm \\
\hline Date Code & $\mathbf{1 9 8 0}$ \\
\hline Colour & Colour \\
\hline Film Polarity & Reversal \\
\hline Element & Camera Original \\
\hline Sound & Magnetic Stripe \\
\hline FPS & Unknown \\
\hline Aspect Ratio & $\mathbf{1 : 3 3 : 1}$ \\
\hline Length & $\mathbf{5 0 . 0} \mathrm{ft}$. \\
\hline Film Wind & Unknown \\
\hline $\begin{array}{l}\text { Stock } \\
\text { Manufacturer/Type }\end{array}$ & Eastman Kodak/ Ektachrome \\
\hline Base Type & Triacetate \\
\hline Splices & 0 \\
\hline Archival Status & Archival Element \\
\hline Overall Condition & Mediocre \\
\hline
\end{tabular}




\begin{tabular}{|l|l|}
\hline Accession Number & $\mathbf{2 0 1 5 . 0 0 0 2 . 0 0 7 8}$ \\
\hline Title & [Glass- Parts on Wall] \\
\hline Gauge & Super 8mm \\
\hline Date Code & $\mathbf{1 9 8 1}$ \\
\hline Colour & Colour \\
\hline Film Polarity & Reversal \\
\hline Element & Camera Original \\
\hline Sound & Magnetic Stripe \\
\hline FPS & Unknown \\
\hline Aspect Ratio & $\mathbf{1 : 3 3 : 1}$ \\
\hline Length & $\mathbf{5 0 . 0}$ ft. \\
\hline Film Wind & Unknown \\
\hline $\begin{array}{l}\text { Stock } \\
\text { Manufacturer/Type }\end{array}$ & Eastman Kodak/ Ektachrome \\
\hline Base Type & Triacetate \\
\hline Splices & O \\
\hline Archival Status & Archival Element \\
\hline Overall Condition & Mediocre \\
\hline
\end{tabular}

\begin{tabular}{|l|l|}
\hline Accession Number & $\mathbf{2 0 1 5 . 0 0 0 2 . 0 0 7 9}$ \\
\hline Title & {$[$ Untitled-July 1980] } \\
\hline Gauge & Super 8mm \\
\hline Date Code & 1980 \\
\hline Colour & Colour \\
\hline Film Polarity & Reversal \\
\hline Element & Camera Original \\
\hline Sound & Silent \\
\hline FPS & Unknown \\
\hline Aspect Ratio & $\mathbf{1 : 3 3 : 1}$ \\
\hline Length & $\mathbf{5 0 . 0} \mathrm{ft}$. \\
\hline Film Wind & B Wind \\
\hline $\begin{array}{l}\text { Stock } \\
\text { Manufacturer/Type }\end{array}$ & Eastman Kodak/ Ektachrome \\
\hline Base Type & Triacetate \\
\hline Splices & 0 \\
\hline Archival Status & Archival Element \\
\hline Overall Condition & Good \\
\hline
\end{tabular}




\begin{tabular}{|l|l|}
\hline Accession Number & $\mathbf{2 0 1 5 . 0 0 0 2 . 0 0 8 0}$ \\
\hline Title & {$[$ Untitled] } \\
\hline Gauge & Super 8mm \\
\hline Date Code & $\mathbf{1 9 8 0}$ \\
\hline Colour & Colour \\
\hline Film Polarity & Reversal \\
\hline Element & Cut Original \\
\hline Sound & Magnetic Stripe \\
\hline FPS & Unknown \\
\hline Aspect Ratio & $\mathbf{1 : 3 3 : 1}$ \\
\hline Length & $\mathbf{5 0 . 0}$ ft. \\
\hline Film Wind & B Wind \\
\hline $\begin{array}{l}\text { Stock } \\
\text { Manufacturer/Type }\end{array}$ & Eastman Kodak/ Ektachrome \\
\hline Base Type & Triacetate \\
\hline Splices & $\mathbf{1}$ \\
\hline Archival Status & Archival Element \\
\hline Overall Condition & Mediocre \\
\hline
\end{tabular}

\begin{tabular}{|l|l|}
\hline Accession Number & 2015.0002 .0081 \\
\hline Title & [Claire's Performance] \\
\hline Gauge & Super 8mm \\
\hline Date Code & 1983 \\
\hline Colour & Colour \\
\hline Film Polarity & Reversal \\
\hline Element & Cut Original \\
\hline Sound & Magnetic Stripe \\
\hline FPS & Unknown \\
\hline Aspect Ratio & $\mathbf{1 : 3 3 : 1}$ \\
\hline Length & $\mathbf{5 0 . 0} \mathrm{ft}$. \\
\hline Film Wind & B Wind \\
\hline $\begin{array}{l}\text { Stock } \\
\text { Manufacturer/Type }\end{array}$ & Eastman Kodak/ Ektachrome \\
\hline Base Type & Triacetate \\
\hline Splices & 1 \\
\hline Archival Status & Archival Element \\
\hline Overall Condition & Mediocre \\
\hline
\end{tabular}




\begin{tabular}{|l|l|}
\hline Accession Number & $\mathbf{2 0 1 5 . 0 0 0 2 . 0 0 8 2}$ \\
\hline Title & [Untitled] \\
\hline Gauge & Super $8 \mathrm{~mm}$ \\
\hline Date Code & $\mathbf{1 9 8 0}$ \\
\hline Colour & Colour \\
\hline Film Polarity & Reversal \\
\hline Element & Cut Original \\
\hline Sound & Magnetic Stripe \\
\hline FPS & Unknown \\
\hline Aspect Ratio & $\mathbf{1 : 3 3 : 1}$ \\
\hline Length & $\mathbf{5 0 . 0}$ ft. \\
\hline Film Wind & B Wind \\
\hline $\begin{array}{l}\text { Stock } \\
\text { Manufacturer/Type }\end{array}$ & Eastman Kodak/ Ektachrome \\
\hline Base Type & Triacetate \\
\hline Splices & $\mathbf{2}$ \\
\hline Archival Status & Archival Element \\
\hline Overall Condition & Good \\
\hline
\end{tabular}

\begin{tabular}{|l|l|}
\hline Accession Number & $\mathbf{2 0 1 5 . 0 0 0 2 . 0 0 8 3}$ \\
\hline Title & [Untitled- Jan 82] \\
\hline Gauge & Super 8mm \\
\hline Date Code & $\mathbf{1 9 7 9}$ \\
\hline Colour & Colour \\
\hline Film Polarity & Reversal \\
\hline Element & Camera Original \\
\hline Sound & Magnetic Stripe \\
\hline FPS & Unknown \\
\hline Aspect Ratio & $\mathbf{1 : 3 3 : 1}$ \\
\hline Length & $\mathbf{5 0 . 0}$ ft. \\
\hline Film Wind & B Wind \\
\hline $\begin{array}{l}\text { Stock } \\
\text { Manufacturer/Type }\end{array}$ & Eastman Kodak/ Ektachrome \\
\hline Base Type & Triacetate \\
\hline Splices & 0 \\
\hline Archival Status & Archival Element \\
\hline Overall Condition & Mediocre \\
\hline
\end{tabular}




\begin{tabular}{|l|l|}
\hline Accession Number & $\mathbf{2 0 1 5 . 0 0 0 2 . 0 0 8 4}$ \\
\hline Title & [Untitled- July 22] \\
\hline Gauge & Super 8mm \\
\hline Date Code & $\mathbf{1 9 8 1}$ \\
\hline Colour & Colour \\
\hline Film Polarity & Reversal \\
\hline Element & Camera Original \\
\hline Sound & Magnetic Stripe \\
\hline FPS & Unknown \\
\hline Aspect Ratio & $\mathbf{1 : 3 3 : 1}$ \\
\hline Length & $\mathbf{5 0 . 0}$ ft. \\
\hline Film Wind & B Wind \\
\hline $\begin{array}{l}\text { Stock } \\
\text { Manufacturer/Type }\end{array}$ & Eastman Kodak/ Ektachrome \\
\hline Base Type & Triacetate \\
\hline Splices & O \\
\hline Archival Status & Archival Element \\
\hline Overall Condition & Medicore \\
\hline
\end{tabular}

\begin{tabular}{|l|l|}
\hline Accession Number & 2015.0002 .0085 \\
\hline Title & [Wednesday's at A's- Dec 3] \\
\hline Gauge & Super 8mm \\
\hline Date Code & 1980 \\
\hline Colour & Colour \\
\hline Film Polarity & Reversal \\
\hline Element & Camera Original \\
\hline Sound & Magnetic Stripe \\
\hline FPS & Unknown \\
\hline Aspect Ratio & $\mathbf{1 : 3 3 : 1}$ \\
\hline Length & $\mathbf{5 0 . 0} \mathrm{ft}$. \\
\hline Film Wind & Unknown \\
\hline $\begin{array}{l}\text { Stock } \\
\text { Manufacturer/Type }\end{array}$ & Eastman Kodak/ Ektachrome \\
\hline Base Type & Triacetate \\
\hline Splices & $\mathbf{0}$ \\
\hline Archival Status & Archival Element \\
\hline Overall Condition & Good \\
\hline
\end{tabular}




\begin{tabular}{|l|l|}
\hline Accession Number & $\mathbf{2 0 1 5 . 0 0 0 2 . 0 0 8 6}$ \\
\hline Title & [Untitled- April 82] \\
\hline Gauge & Super 8mm \\
\hline Date Code & $\mathbf{1 9 8 2}$ \\
\hline Colour & Colour \\
\hline Film Polarity & Reversal \\
\hline Element & Cut Original \\
\hline Sound & Magnetic Stripe \\
\hline FPS & Unknown \\
\hline Aspect Ratio & $\mathbf{1 : 3 3 : 1}$ \\
\hline Length & $\mathbf{5 0 . 0}$ ft. \\
\hline Film Wind & Unknown \\
\hline $\begin{array}{l}\text { Stock } \\
\text { Manufacturer/Type }\end{array}$ & Eastman Kodak/ Ektachrome \\
\hline Base Type & Triacetate \\
\hline Splices & 4 \\
\hline Archival Status & Archival Element \\
\hline Overall Condition & Good \\
\hline
\end{tabular}

\begin{tabular}{|l|l|}
\hline Accession Number & $\mathbf{2 0 1 5 . 0 0 0 2 . 0 0 8 7}$ \\
\hline Title & {$[$ Untitled- Nov 80] } \\
\hline Gauge & Super 8mm \\
\hline Date Code & $\mathbf{1 9 8 0}$ \\
\hline Colour & Colour \\
\hline Film Polarity & Reversal \\
\hline Element & Camera Original \\
\hline Sound & Magnetic Stripe \\
\hline FPS & Unknown \\
\hline Aspect Ratio & $\mathbf{1 : 3 3 : 1}$ \\
\hline Length & $\mathbf{5 0 . 0} \mathrm{ft}$. \\
\hline Film Wind & B Wind \\
\hline $\begin{array}{l}\text { Stock } \\
\text { Manufacturer/Type }\end{array}$ & Eastman Kodak/ Ektachrome \\
\hline Base Type & Triacetate \\
\hline Splices & $\mathbf{0}$ \\
\hline Archival Status & Archival Element \\
\hline Overall Condition & Good \\
\hline
\end{tabular}




\begin{tabular}{|l|l|}
\hline Accession Number & $\mathbf{2 0 1 5 . 0 0 0 2 . 0 0 8 8}$ \\
\hline Title & {$[$ A's 80] } \\
\hline Gauge & Super 8mm \\
\hline Date Code & $\mathbf{1 9 7 9}$ \\
\hline Colour & Colour \\
\hline Film Polarity & Reversal \\
\hline Element & Camera Original \\
\hline Sound & Silent \\
\hline FPS & Unknown \\
\hline Aspect Ratio & $\mathbf{1 : 3 3 : 1}$ \\
\hline Length & $\mathbf{5 0 . 0}$ ft. \\
\hline Film Wind & Unknown \\
\hline $\begin{array}{l}\text { Stock } \\
\text { Manufacturer/Type }\end{array}$ & Eastman Kodak/ Ektachrome \\
\hline Base Type & Triacetate \\
\hline Splices & O \\
\hline Archival Status & Archival Element \\
\hline Overall Condition & Mediocre \\
\hline
\end{tabular}

\begin{tabular}{|l|l|}
\hline Accession Number & $\mathbf{2 0 1 5 . 0 0 0 2 . 0 0 8 9}$ \\
\hline Title & {$[$ Inside-Outside \#3] } \\
\hline Gauge & Super 8mm \\
\hline Date Code & $\mathbf{1 9 8 0}$ \\
\hline Colour & Colour \\
\hline Film Polarity & Reversal \\
\hline Element & Cut Original \\
\hline Sound & Magnetic Stripe \\
\hline FPS & Unknown \\
\hline Aspect Ratio & $\mathbf{1 : 3 3 : 1}$ \\
\hline Length & $\mathbf{5 0 . 0}$ ft. \\
\hline Film Wind & B Wind \\
\hline $\begin{array}{l}\text { Stock } \\
\text { Manufacturer/Type }\end{array}$ & Eastman Kodak/ Ektachrome \\
\hline Base Type & Triacetate \\
\hline Splices & $\mathbf{2}$ \\
\hline Archival Status & Archival Element \\
\hline Overall Condition & Good \\
\hline
\end{tabular}




\begin{tabular}{|l|l|}
\hline Accession Number & $\mathbf{2 0 1 5 . 0 0 0 2 . 0 0 9 0}$ \\
\hline Title & [Untitled] \\
\hline Gauge & Super $8 \mathrm{~mm}$ \\
\hline Date Code & $\mathbf{1 9 8 0}$ \\
\hline Colour & Colour \\
\hline Film Polarity & Reversal \\
\hline Element & Camera Original \\
\hline Sound & Magnetic Stripe \\
\hline FPS & Unknown \\
\hline Aspect Ratio & $\mathbf{1 : 3 3 : 1}$ \\
\hline Length & $\mathbf{5 0 . 0}$ ft. \\
\hline Film Wind & B Wind \\
\hline $\begin{array}{l}\text { Stock } \\
\text { Manufacturer/Type }\end{array}$ & Eastman Kodak/ Ektachrome \\
\hline Base Type & Triacetate \\
\hline Splices & O \\
\hline Archival Status & Archival Element \\
\hline Overall Condition & Good \\
\hline
\end{tabular}

\begin{tabular}{|l|l|}
\hline Accession Number & 2015.0002 .0091 \\
\hline Title & {$[$ Film \#1] } \\
\hline Gauge & Super 8mm \\
\hline Date Code & 1981 \\
\hline Colour & Colour \\
\hline Film Polarity & Reversal \\
\hline Element & Cut Original \\
\hline Sound & Magnetic Stripe \\
\hline FPS & Unknown \\
\hline Aspect Ratio & $\mathbf{1 : 3 3 : 1}$ \\
\hline Length & $\mathbf{5 0 . 0} \mathrm{ft}$. \\
\hline Film Wind & Unknown \\
\hline $\begin{array}{l}\text { Stock } \\
\text { Manufacturer/Type }\end{array}$ & Eastman Kodak/ Ektachrome \\
\hline Base Type & Triacetate \\
\hline Splices & $\mathbf{1}$ \\
\hline Archival Status & Archival Element \\
\hline Overall Condition & Good \\
\hline
\end{tabular}




\begin{tabular}{|l|l|}
\hline Accession Number & $\mathbf{2 0 1 5 . 0 0 0 2 . 0 0 9 2}$ \\
\hline Title & {$[$ Film \#2] } \\
\hline Gauge & Super $8 \mathrm{~mm}$ \\
\hline Date Code & $\mathbf{1 9 8 0}$ \\
\hline Colour & Colour \\
\hline Film Polarity & Reversal \\
\hline Element & Cut Original \\
\hline Sound & Magnetic Stripe \\
\hline FPS & Unknown \\
\hline Aspect Ratio & $\mathbf{1 : 3 3 : 1}$ \\
\hline Length & $\mathbf{5 0 . 0}$ ft. \\
\hline Film Wind & B Wind \\
\hline $\begin{array}{l}\text { Stock } \\
\text { Manufacturer/Type }\end{array}$ & Eastman Kodak/ Ektachrome \\
\hline Base Type & Triacetate \\
\hline Splices & $\mathbf{1}$ \\
\hline Archival Status & Archival Element \\
\hline Overall Condition & Good \\
\hline
\end{tabular}

\begin{tabular}{|l|l|}
\hline Accession Number & $\mathbf{2 0 1 5 . 0 0 0 2 . 0 0 9 3}$ \\
\hline Title & City Jungle Beast \\
\hline Gauge & Super 8mm \\
\hline Date Code & $\mathbf{1 9 7 9}$ \\
\hline Colour & Colour \\
\hline Film Polarity & Reversal \\
\hline Element & Camera Original \\
\hline Sound & Magnetic Stripe \\
\hline FPS & Unknown \\
\hline Aspect Ratio & $\mathbf{1 : 3 3 : 1}$ \\
\hline Length & $\mathbf{5 0 . 0}$ ft. \\
\hline Film Wind & Unknown \\
\hline $\begin{array}{l}\text { Stock } \\
\text { Manufacturer/Type }\end{array}$ & Eastman Kodak/ Ektachrome \\
\hline Base Type & Triacetate \\
\hline Splices & O \\
\hline Archival Status & Archival Element \\
\hline Overall Condition & Good \\
\hline
\end{tabular}




\begin{tabular}{|l|l|}
\hline Accession Number & $\mathbf{2 0 1 5 . 0 0 0 2 . 0 0 9 4}$ \\
\hline Title & [Untitled- Very Dark] \\
\hline Gauge & Super 8mm \\
\hline Date Code & $\mathbf{1 9 8 4}$ \\
\hline Colour & Colour \\
\hline Film Polarity & Reversal \\
\hline Element & Camera Original \\
\hline Sound & Magnetic Stripe \\
\hline FPS & Unknown \\
\hline Aspect Ratio & $\mathbf{1 : 3 3 : 1}$ \\
\hline Length & $\mathbf{5 0 . 0}$ ft. \\
\hline Film Wind & B Wind \\
\hline $\begin{array}{l}\text { Stock } \\
\text { Manufacturer/Type }\end{array}$ & Eastman Kodak/ Ektachrome \\
\hline Base Type & Triacetate \\
\hline Splices & O \\
\hline Archival Status & Archival Element \\
\hline Overall Condition & Good \\
\hline
\end{tabular}

\begin{tabular}{|l|l|}
\hline Accession Number & $\mathbf{2 0 1 5 . 0 0 0 2 . 0 0 9 5}$ \\
\hline Title & [Church, Farm] \\
\hline Gauge & Super 8mm \\
\hline Date Code & $\mathbf{1 9 7 9 , 1 9 8 0}$ \\
\hline Colour & Colour \\
\hline Film Polarity & Reversal \\
\hline Element & Camera Original \\
\hline Sound & Magnetic Stripe \\
\hline FPS & Unknown \\
\hline Aspect Ratio & $\mathbf{1 : 3 3 : 1}$ \\
\hline Length & $\mathbf{5 0 . 0}$ ft. \\
\hline Film Wind & B Wind \\
\hline $\begin{array}{l}\text { Stock } \\
\text { Manufacturer/Type }\end{array}$ & Eastman Kodak/ Ektachrome \\
\hline Base Type & Triacetate \\
\hline Splices & O \\
\hline Archival Status & Archival Element \\
\hline Overall Condition & Good \\
\hline
\end{tabular}




\begin{tabular}{|l|l|}
\hline Accession Number & $\mathbf{2 0 1 5 . 0 0 0 2 . 0 0 9 6}$ \\
\hline Title & {$[$ Lenny Bruce Without Bars- Club 57] } \\
\hline Gauge & Super 8mm \\
\hline Date Code & Unknown \\
\hline Colour & Colour \\
\hline Film Polarity & Reversal \\
\hline Element & Cut Original \\
\hline Sound & Magnetic Stripe \\
\hline FPS & Unknown \\
\hline Aspect Ratio & $\mathbf{1 : 3 3 : 1}$ \\
\hline Length & $\mathbf{5 0 . 0}$ ft. \\
\hline Film Wind & B Wind \\
\hline $\begin{array}{l}\text { Stock } \\
\text { Manufacturer/Type }\end{array}$ & Eastman Kodak/ Ektachrome \\
\hline Base Type & Triacetate \\
\hline Splices & O \\
\hline Archival Status & Archival Element \\
\hline Overall Condition & Good \\
\hline
\end{tabular}

\begin{tabular}{|l|l|}
\hline Accession Number & $\mathbf{2 0 1 5 . 0 0 0 2 . 0 0 9 7}$ \\
\hline Title & {$[$ Untitled-Oct 81] } \\
\hline Gauge & Super 8mm \\
\hline Date Code & Unknown \\
\hline Colour & Colour \\
\hline Film Polarity & Reversal \\
\hline Element & Cut Original \\
\hline Sound & Magnetic Stripe \\
\hline FPS & Unknown \\
\hline Aspect Ratio & $\mathbf{1 : 3 3 : 1}$ \\
\hline Length & $\mathbf{5 0 . 0} \mathrm{ft}$. \\
\hline Film Wind & B Wind \\
\hline $\begin{array}{l}\text { Stock } \\
\text { Manufacturer/Type }\end{array}$ & Eastman Kodak/ Ektachrome \\
\hline Base Type & Triacetate \\
\hline Splices & $\mathbf{1}$ \\
\hline Archival Status & Archival Element \\
\hline Overall Condition & Good \\
\hline
\end{tabular}




\begin{tabular}{|l|l|}
\hline Accession Number & $\mathbf{2 0 1 5 . 0 0 0 2 . 0 0 9 8}$ \\
\hline Title & {$[$ A's \#1, Oct 1] } \\
\hline Gauge & Super 8mm \\
\hline Date Code & $\mathbf{1 9 8 0}$ \\
\hline Colour & Colour \\
\hline Film Polarity & Reversal \\
\hline Element & Camera Original \\
\hline Sound & Magnetic Stripe \\
\hline FPS & Unknown \\
\hline Aspect Ratio & $\mathbf{1 : 3 3 : 1}$ \\
\hline Length & $\mathbf{5 0 . 0}$ ft. \\
\hline Film Wind & B Wind \\
\hline $\begin{array}{l}\text { Stock } \\
\text { Manufacturer/Type }\end{array}$ & Eastman Kodak/ Ektachrome \\
\hline Base Type & Triacetate \\
\hline Splices & O \\
\hline Archival Status & Archival Element \\
\hline Overall Condition & Good \\
\hline
\end{tabular}

\begin{tabular}{|l|l|}
\hline Accession Number & $\mathbf{2 0 1 5 . 0 0 0 2 . 0 0 9 9}$ \\
\hline Title & {$[$ Oct 16, 1981] } \\
\hline Gauge & Super 8mm \\
\hline Date Code & $\mathbf{1 9 8 1}$ \\
\hline Colour & Colour \\
\hline Film Polarity & Reversal \\
\hline Element & Camera Original \\
\hline Sound & Magnetic Stripe \\
\hline FPS & Unknown \\
\hline Aspect Ratio & $\mathbf{1 : 3 3 : 1}$ \\
\hline Length & $\mathbf{5 0 . 0}$ ft. \\
\hline Film Wind & Unknown \\
\hline $\begin{array}{l}\text { Stock } \\
\text { Manufacturer/Type }\end{array}$ & Eastman Kodak/ Ektachrome \\
\hline Base Type & Triacetate \\
\hline Splices & O \\
\hline Archival Status & Archival Element \\
\hline Overall Condition & Good \\
\hline
\end{tabular}




\begin{tabular}{|l|l|}
\hline Accession Number & $\mathbf{2 0 1 5 . 0 0 0 2 . 0 1 0 0}$ \\
\hline Title & {$[$ Subway, Gowanus] } \\
\hline Gauge & Super 8mm \\
\hline Date Code & $\mathbf{1 9 8 0}$ \\
\hline Colour & Colour \\
\hline Film Polarity & Reversal \\
\hline Element & Camera Original \\
\hline Sound & Magnetic Stripe \\
\hline FPS & Unknown \\
\hline Aspect Ratio & $\mathbf{1 : 3 3 : 1}$ \\
\hline Length & $\mathbf{5 0 . 0}$ ft. \\
\hline Film Wind & B Wind \\
\hline $\begin{array}{l}\text { Stock } \\
\text { Manufacturer/Type }\end{array}$ & Eastman Kodak/ Kodachrome \\
\hline Base Type & Triacetate \\
\hline Splices & O \\
\hline Archival Status & Archival Element \\
\hline Overall Condition & Good \\
\hline
\end{tabular}

\begin{tabular}{|l|l|}
\hline Accession Number & $\mathbf{2 0 1 5 . 0 0 0 2 . 0 1 0 1}$ \\
\hline Title & [Untitled-82] \\
\hline Gauge & Super $8 \mathrm{~mm}$ \\
\hline Date Code & $\mathbf{1 9 8 2}$ \\
\hline Colour & Colour \\
\hline Film Polarity & Reversal \\
\hline Element & Cut Original \\
\hline Sound & Magnetic Stripe \\
\hline FPS & Unknown \\
\hline Aspect Ratio & $\mathbf{1 : 3 3 : 1}$ \\
\hline Length & $\mathbf{5 0 . 0}$ ft. \\
\hline Film Wind & B Wind \\
\hline $\begin{array}{l}\text { Stock } \\
\text { Manufacturer/Type }\end{array}$ & Eastman Kodak/ Ektachrome \\
\hline Base Type & Triacetate \\
\hline Splices & $\mathbf{1}$ \\
\hline Archival Status & Archival Element \\
\hline Overall Condition & Poor \\
\hline
\end{tabular}




\begin{tabular}{|l|l|}
\hline Accession Number & $\mathbf{2 0 1 5 . 0 0 0 2 . 0 1 0 2}$ \\
\hline Title & {$[$ Rain- Truck Ride] } \\
\hline Gauge & Super 8mm \\
\hline Date Code & $\mathbf{1 9 8 0}$ \\
\hline Colour & Colour \\
\hline Film Polarity & Reversal \\
\hline Element & Camera Original \\
\hline Sound & Magnetic Stripe \\
\hline FPS & Unknown \\
\hline Aspect Ratio & $\mathbf{1 : 3 3 : 1}$ \\
\hline Length & $\mathbf{5 0 . 0}$ ft. \\
\hline Film Wind & B Wind \\
\hline $\begin{array}{l}\text { Stock } \\
\text { Manufacturer/Type }\end{array}$ & Eastman Kodak/ Ektachrome \\
\hline Base Type & Triacetate \\
\hline Splices & O \\
\hline Archival Status & Archival Element \\
\hline Overall Condition & Good \\
\hline
\end{tabular}

\begin{tabular}{|l|l|}
\hline Accession Number & $\mathbf{2 0 1 5 . 0 0 0 2 . 0 1 0 3}$ \\
\hline Title & Test+XYZ \\
\hline Gauge & Super $8 \mathrm{~mm}$ \\
\hline Date Code & $\mathbf{1 9 8 0}$ \\
\hline Colour & Colour \\
\hline Film Polarity & Reversal \\
\hline Element & Cut Original \\
\hline Sound & Magnetic Stripe \\
\hline FPS & Unknown \\
\hline Aspect Ratio & $\mathbf{1 : 3 3 : 1}$ \\
\hline Length & $\mathbf{5 0 . 0} \mathrm{ft}$. \\
\hline Film Wind & B Wind \\
\hline $\begin{array}{l}\text { Stock } \\
\text { Manufacturer/Type }\end{array}$ & Eastman Kodak/ Kodachrome \\
\hline Base Type & Triacetate \\
\hline Splices & $\mathbf{2}$ \\
\hline Archival Status & Archival Element \\
\hline Overall Condition & Good \\
\hline
\end{tabular}




\begin{tabular}{|l|l|}
\hline Accession Number & $\mathbf{2 0 1 5 . 0 0 0 2 . 0 1 0 4}$ \\
\hline Title & {$[$ Some Letters] } \\
\hline Gauge & Super $8 \mathrm{~mm}$ \\
\hline Date Code & $\mathbf{1 9 8 5}$ \\
\hline Colour & Colour \\
\hline Film Polarity & Reversal \\
\hline Element & Cut Original \\
\hline Sound & Magnetic Stripe \\
\hline FPS & Unknown \\
\hline Aspect Ratio & $\mathbf{1 : 3 3 : 1}$ \\
\hline Length & $\mathbf{5 0 . 0}$ ft. \\
\hline Film Wind & Unknown \\
\hline $\begin{array}{l}\text { Stock } \\
\text { Manufacturer/Type }\end{array}$ & Eastman Kodak/ Kodachrome \\
\hline Base Type & Triacetate \\
\hline Splices & $\mathbf{1}$ \\
\hline Archival Status & Archival Element \\
\hline Overall Condition & Good \\
\hline
\end{tabular}

\begin{tabular}{|l|l|}
\hline Accession Number & $\mathbf{2 0 1 5 . 0 0 0 2 . 0 1 0 5}$ \\
\hline Title & {$[$ How She Part 2] } \\
\hline Gauge & Super 8mm \\
\hline Date Code & 1980 \\
\hline Colour & Colour \\
\hline Film Polarity & Reversal \\
\hline Element & Camera Original \\
\hline Sound & Magnetic Stripe \\
\hline FPS & Unknown \\
\hline Aspect Ratio & $\mathbf{1 : 3 3 : 1}$ \\
\hline Length & $\mathbf{1 0 . 0} \mathrm{ft.}$ \\
\hline Film Wind & Unknown \\
\hline $\begin{array}{l}\text { Stock } \\
\text { Manufacturer/Type }\end{array}$ & Eastman Kodak/ Ektachrome \\
\hline Base Type & Triacetate \\
\hline Splices & 0 \\
\hline Archival Status & Archival Element \\
\hline Overall Condition & Good \\
\hline
\end{tabular}




\begin{tabular}{|l|l|}
\hline Accession Number & $\mathbf{2 0 1 5 . 0 0 0 2 . 0 1 0 6}$ \\
\hline Title & $\mathbf{4 4}^{\text {th }}+\mathbf{9}^{\text {th }}$ Test \\
\hline Gauge & Super $\mathbf{m m m}$ \\
\hline Date Code & $\mathbf{1 9 8 4}$ \\
\hline Colour & Colour \\
\hline Film Polarity & Reversal \\
\hline Element & Cut Original \\
\hline Sound & Magnetic Stripe \\
\hline FPS & Unknown \\
\hline Aspect Ratio & $1: 33: 1$ \\
\hline Length & $\mathbf{5 0 . 0}$ ft. \\
\hline Film Wind & B Wind \\
\hline $\begin{array}{l}\text { Stock } \\
\text { Manufacturer/Type }\end{array}$ & Eastman Kodak/ Kodachrome \\
\hline Base Type & Triacetate \\
\hline Splices & $\mathbf{2}$ \\
\hline Archival Status & Archival Element \\
\hline Overall Condition & Good \\
\hline
\end{tabular}

\begin{tabular}{|l|l|}
\hline Accession Number & 2015.0002.0107 \\
\hline Title & [June 21 Performance] \\
\hline Gauge & Super 8mm \\
\hline Date Code & $\mathbf{1 9 8 0}$ \\
\hline Colour & Colour \\
\hline Film Polarity & Reversal \\
\hline Element & Camera Original \\
\hline Sound & Magnetic Stripe \\
\hline FPS & Unknown \\
\hline Aspect Ratio & $\mathbf{1 : 3 3 : 1}$ \\
\hline Length & $\mathbf{5 0 . 0}$ ft. \\
\hline Film Wind & B Wind \\
\hline $\begin{array}{l}\text { Stock } \\
\text { Manufacturer/Type }\end{array}$ & Eastman Kodak/ Ektachrome \\
\hline Base Type & Triacetate \\
\hline Splices & 0 \\
\hline Archival Status & Archival Element \\
\hline Overall Condition & Good \\
\hline
\end{tabular}




\begin{tabular}{|l|l|}
\hline Accession Number & $\mathbf{2 0 1 5 . 0 0 0 2 . 0 1 0 8}$ \\
\hline Title & {$[$ Untitled] } \\
\hline Gauge & Super $\mathbf{m m m}$ \\
\hline Date Code & $\mathbf{1 9 8 0}$ \\
\hline Colour & Colour \\
\hline Film Polarity & Reversal \\
\hline Element & Cut Original \\
\hline Sound & Magnetic Stripe \\
\hline FPS & Unknown \\
\hline Aspect Ratio & $\mathbf{1 : 3 3 : 1}$ \\
\hline Length & $\mathbf{5 0 . 0}$ ft. \\
\hline Film Wind & Unknown \\
\hline $\begin{array}{l}\text { Stock } \\
\text { Manufacturer/Type }\end{array}$ & Eastman Kodak/ Ektachrome \\
\hline Base Type & Triacetate \\
\hline Splices & $\mathbf{2}$ \\
\hline Archival Status & Archival Element \\
\hline Overall Condition & Mediocre \\
\hline
\end{tabular}

\begin{tabular}{|l|l|}
\hline Accession Number & $\mathbf{2 0 1 5 . 0 0 0 2 . 0 1 0 9}$ \\
\hline Title & {$[$ Tuesday Sept 8, 1981] } \\
\hline Gauge & Super 8mm \\
\hline Date Code & $\mathbf{1 9 8 0}$ \\
\hline Colour & Colour \\
\hline Film Polarity & Reversal \\
\hline Element & Camera Original \\
\hline Sound & Magnetic Stripe \\
\hline FPS & Unknown \\
\hline Aspect Ratio & $\mathbf{1 : 3 3 : 1}$ \\
\hline Length & $\mathbf{5 0 . 0}$ ft. \\
\hline Film Wind & B Wind \\
\hline $\begin{array}{l}\text { Stock } \\
\text { Manufacturer/Type }\end{array}$ & Eastman Kodak/ Ektachrome \\
\hline Base Type & Triacetate \\
\hline Splices & O \\
\hline Archival Status & Archival Element \\
\hline Overall Condition & Good \\
\hline
\end{tabular}




\begin{tabular}{|l|l|}
\hline Accession Number & $\mathbf{2 0 1 5 . 0 0 0 2 . 0 1 1 0}$ \\
\hline Title & {$[$ Day of Reagan Shooting] } \\
\hline Gauge & Super 8mm \\
\hline Date Code & $\mathbf{1 9 8 0}$ \\
\hline Colour & Colour \\
\hline Film Polarity & Reversal \\
\hline Element & Camera Original \\
\hline Sound & Magnetic Stripe \\
\hline FPS & Unknown \\
\hline Aspect Ratio & $\mathbf{1 : 3 3 : 1}$ \\
\hline Length & $\mathbf{5 0 . 0}$ ft. \\
\hline Film Wind & B Wind \\
\hline $\begin{array}{l}\text { Stock } \\
\text { Manufacturer/Type }\end{array}$ & Eastman Kodak/ Ektachrome \\
\hline Base Type & Triacetate \\
\hline Splices & O \\
\hline Archival Status & Archival Element \\
\hline Overall Condition & Good \\
\hline
\end{tabular}

\begin{tabular}{|l|l|}
\hline Accession Number & $\mathbf{2 0 1 5 . 0 0 0 2 . 0 1 1 1}$ \\
\hline Title & {$[$ Oct 8 Performance] } \\
\hline Gauge & Super 8mm \\
\hline Date Code & $\mathbf{1 9 8 1}$ \\
\hline Colour & Colour \\
\hline Film Polarity & Reversal \\
\hline Element & Camera Original \\
\hline Sound & Magnetic Stripe \\
\hline FPS & Unknown \\
\hline Aspect Ratio & $\mathbf{1 : 3 3 : 1}$ \\
\hline Length & $\mathbf{5 0 . 0}$ ft. \\
\hline Film Wind & B Wind \\
\hline $\begin{array}{l}\text { Stock } \\
\text { Manufacturer/Type }\end{array}$ & Eastman Kodak/ Ektachrome \\
\hline Base Type & Triacetate \\
\hline Splices & O \\
\hline Archival Status & Archival Element \\
\hline Overall Condition & Good \\
\hline
\end{tabular}




\begin{tabular}{|l|l|}
\hline Accession Number & $\mathbf{2 0 1 5 . 0 0 0 2 . 0 1 1 2}$ \\
\hline Title & {$[$ Cable TV- June 12] } \\
\hline Gauge & Super 8mm \\
\hline Date Code & $\mathbf{1 9 8 2}$ \\
\hline Colour & Colour \\
\hline Film Polarity & Reversal \\
\hline Element & Camera Original \\
\hline Sound & Magnetic Stripe \\
\hline FPS & Unknown \\
\hline Aspect Ratio & $\mathbf{1 : 3 3 : 1}$ \\
\hline Length & $\mathbf{5 0 . 0}$ ft. \\
\hline Film Wind & B Wind \\
\hline $\begin{array}{l}\text { Stock } \\
\text { Manufacturer/Type }\end{array}$ & Eastman Kodak/ Ektachrome \\
\hline Base Type & Triacetate \\
\hline Splices & 0 \\
\hline Archival Status & Archival Element \\
\hline Overall Condition & Good \\
\hline
\end{tabular}

\begin{tabular}{|l|l|}
\hline Accession Number & $\mathbf{2 0 1 5 . 0 0 0 2 . 0 1 1 3}$ \\
\hline Title & [Untitled- Feb 82] \\
\hline Gauge & Super 8mm \\
\hline Date Code & $\mathbf{1 9 8 2}$ \\
\hline Colour & Colour \\
\hline Film Polarity & Reversal \\
\hline Element & Camera Original \\
\hline Sound & Magnetic Stripe \\
\hline FPS & Unknown \\
\hline Aspect Ratio & $\mathbf{1 : 3 3 : 1}$ \\
\hline Length & $\mathbf{5 0 . 0}$ ft. \\
\hline Film Wind & B Wind \\
\hline $\begin{array}{l}\text { Stock } \\
\text { Manufacturer/Type }\end{array}$ & Eastman Kodak/ Ektachrome \\
\hline Base Type & Triacetate \\
\hline Splices & O \\
\hline Archival Status & Archival Element \\
\hline Overall Condition & Good \\
\hline
\end{tabular}




\begin{tabular}{|l|l|}
\hline Accession Number & $\mathbf{2 0 1 5 . 0 0 0 2 . 0 1 1 4}$ \\
\hline Title & $\mathbf{8 6}$ Rivington \\
\hline Gauge & Super 8mm \\
\hline Date Code & $\mathbf{1 9 8 4}$ \\
\hline Colour & Colour \\
\hline Film Polarity & Reversal \\
\hline Element & Camera Original \\
\hline Sound & Magnetic Stripe \\
\hline FPS & Unknown \\
\hline Aspect Ratio & $\mathbf{1 : 3 3 : 1}$ \\
\hline Length & $\mathbf{5 0 . 0}$ ft. \\
\hline Film Wind & B Wind \\
\hline $\begin{array}{l}\text { Stock } \\
\text { Manufacturer/Type }\end{array}$ & Eastman Kodak/ Kodachrome \\
\hline Base Type & Triacetate \\
\hline Splices & 0 \\
\hline Archival Status & Archival Element \\
\hline Overall Condition & Mediocre \\
\hline
\end{tabular}

\begin{tabular}{|l|l|}
\hline Accession Number & $\mathbf{2 0 1 5 . 0 0 0 2 . 0 1 1 5}$ \\
\hline Title & {$[$ April 14-15] } \\
\hline Gauge & Super 8mm \\
\hline Date Code & 1980 \\
\hline Colour & Colour \\
\hline Film Polarity & Reversal \\
\hline Element & Camera Original \\
\hline Sound & Magnetic Stripe \\
\hline FPS & Unknown \\
\hline Aspect Ratio & $\mathbf{1 : 3 3 : 1}$ \\
\hline Length & $\mathbf{5 0 . 0} \mathrm{ft}$. \\
\hline Film Wind & Unknown Wind \\
\hline $\begin{array}{l}\text { Stock } \\
\text { Manufacturer/Type }\end{array}$ & Eastman Kodak/ Ektachrome \\
\hline Base Type & Triacetate \\
\hline Splices & 0 \\
\hline Archival Status & Archival Element \\
\hline Overall Condition & Good \\
\hline
\end{tabular}




\begin{tabular}{|l|l|}
\hline Accession Number & $\mathbf{2 0 1 5 . 0 0 0 2 . 0 1 1 6}$ \\
\hline Title & {$[$ TV \& Film- July 1,2] } \\
\hline Gauge & Super 8mm \\
\hline Date Code & $\mathbf{1 9 8 0}$ \\
\hline Colour & Colour \\
\hline Film Polarity & Reversal \\
\hline Element & Camera Original \\
\hline Sound & Magnetic Stripe \\
\hline FPS & Unknown \\
\hline Aspect Ratio & $\mathbf{1 : 3 3 : 1}$ \\
\hline Length & $\mathbf{5 0 . 0}$ ft. \\
\hline Film Wind & B Wind \\
\hline $\begin{array}{l}\text { Stock } \\
\text { Manufacturer/Type }\end{array}$ & Eastman Kodak/ Ektachrome \\
\hline Base Type & Triacetate \\
\hline Splices & 0 \\
\hline Archival Status & Archival Element \\
\hline Overall Condition & Good \\
\hline
\end{tabular}

\begin{tabular}{|l|l|}
\hline Accession Number & $\mathbf{2 0 1 5 . 0 0 0 2 . 0 1 1 7}$ \\
\hline Title & [Untitled- July 80] \\
\hline Gauge & Super 8mm \\
\hline Date Code & $\mathbf{1 9 7 9}$ \\
\hline Colour & Colour \\
\hline Film Polarity & Reversal \\
\hline Element & Camera Original \\
\hline Sound & Magnetic Stripe \\
\hline FPS & Unknown \\
\hline Aspect Ratio & $\mathbf{1 : 3 3 : 1}$ \\
\hline Length & $\mathbf{5 0 . 0}$ ft. \\
\hline Film Wind & B Wind \\
\hline $\begin{array}{l}\text { Stock } \\
\text { Manufacturer/Type }\end{array}$ & Eastman Kodak/ Ektachrome \\
\hline Base Type & Triacetate \\
\hline Splices & O \\
\hline Archival Status & Archival Element \\
\hline Overall Condition & Mediocre \\
\hline
\end{tabular}




\begin{tabular}{|l|l|}
\hline Accession Number & 2015.0002 .0118 \\
\hline Title & {$[$ P.S 19/Rivington School] } \\
\hline Gauge & Super 8mm \\
\hline Date Code & Unknown \\
\hline Colour & Colour \\
\hline Film Polarity & Reversal \\
\hline Element & Camera Original \\
\hline Sound & Magnetic Stripe \\
\hline FPS & Unknown \\
\hline Aspect Ratio & $\mathbf{1 : 3 3 : 1}$ \\
\hline Length & $\mathbf{5 0 . 0} \mathrm{ft}$. \\
\hline Film Wind & B Wind \\
\hline $\begin{array}{l}\text { Stock } \\
\text { Manufacturer/Type }\end{array}$ & Eastman Kodak/ Kodachrome \\
\hline Base Type & Triacetate \\
\hline Splices & 0 \\
\hline Archival Status & Archival Element \\
\hline Overall Condition & Good \\
\hline
\end{tabular}

\begin{tabular}{|l|l|}
\hline Accession Number & $\mathbf{2 0 1 5 . 0 0 0 2 . 0 1 1 9}$ \\
\hline Title & [Aug. 1980] \\
\hline Gauge & Super 8mm \\
\hline Date Code & $\mathbf{1 9 7 9}$ \\
\hline Colour & Colour \\
\hline Film Polarity & Reversal \\
\hline Element & Camera Original \\
\hline Sound & Magnetic Stripe \\
\hline FPS & Unknown \\
\hline Aspect Ratio & $\mathbf{1 : 3 3 : 1}$ \\
\hline Length & $\mathbf{5 0 . 0}$ ft. \\
\hline Film Wind & B Wind \\
\hline $\begin{array}{l}\text { Stock } \\
\text { Manufacturer/Type }\end{array}$ & Eastman Kodak/ Ektachrome \\
\hline Base Type & Triacetate \\
\hline Splices & O \\
\hline Archival Status & Archival Element \\
\hline Overall Condition & Good \\
\hline
\end{tabular}




\begin{tabular}{|l|l|}
\hline Accession Number & $\mathbf{2 0 1 5 . 0 0 0 2 . 0 1 2 0}$ \\
\hline Title & {$[$ Grandma 90] } \\
\hline Gauge & Super 8mm \\
\hline Date Code & $\mathbf{1 9 8 2}$ \\
\hline Colour & Colour \\
\hline Film Polarity & Reversal \\
\hline Element & Camera Original \\
\hline Sound & Magnetic Stripe \\
\hline FPS & Unknown \\
\hline Aspect Ratio & $\mathbf{1 : 3 3 : 1}$ \\
\hline Length & $\mathbf{5 0 . 0}$ ft. \\
\hline Film Wind & B Wind \\
\hline $\begin{array}{l}\text { Stock } \\
\text { Manufacturer/Type }\end{array}$ & Eastman Kodak/ Ektachrome \\
\hline Base Type & Triacetate \\
\hline Splices & O \\
\hline Archival Status & Archival Element \\
\hline Overall Condition & Mediocre \\
\hline
\end{tabular}

\begin{tabular}{|l|l|}
\hline Accession Number & $\mathbf{2 0 1 5 . 0 0 0 2 . 0 1 2 1}$ \\
\hline Title & {$[$ Higgins Auction 81] } \\
\hline Gauge & Super 8mm \\
\hline Date Code & $\mathbf{1 9 8 0}$ \\
\hline Colour & Colour \\
\hline Film Polarity & Reversal \\
\hline Element & Camera Original \\
\hline Sound & Magnetic Stripe \\
\hline FPS & Unknown \\
\hline Aspect Ratio & $1: 33: 1$ \\
\hline Length & $\mathbf{2 0 . 0}$ ft. \\
\hline Film Wind & B Wind \\
\hline $\begin{array}{l}\text { Stock } \\
\text { Manufacturer/Type }\end{array}$ & Eastman Kodak/ Ektachrome \\
\hline Base Type & Triacetate \\
\hline Splices & O \\
\hline Archival Status & Archival Element \\
\hline Overall Condition & Good \\
\hline
\end{tabular}




\begin{tabular}{|l|l|}
\hline Accession Number & $\mathbf{2 0 1 5 . 0 0 0 2 . 0 1 2 2}$ \\
\hline Title & {$[$ Untitled] } \\
\hline Gauge & Super $8 \mathrm{~mm}$ \\
\hline Date Code & $\mathbf{1 9 8 4}$ \\
\hline Colour & Colour \\
\hline Film Polarity & Reversal \\
\hline Element & Cut Original \\
\hline Sound & Magnetic Stripe \\
\hline FPS & Unknown \\
\hline Aspect Ratio & $\mathbf{1 : 3 3 : 1}$ \\
\hline Length & $\mathbf{5 0 . 0}$ ft. \\
\hline Film Wind & B Wind \\
\hline $\begin{array}{l}\text { Stock } \\
\text { Manufacturer/Type }\end{array}$ & Eastman Kodak/ Kodachrome \\
\hline Base Type & Triacetate \\
\hline Splices & $\mathbf{4}$ \\
\hline Archival Status & Archival Element \\
\hline Overall Condition & Good \\
\hline
\end{tabular}

\begin{tabular}{|l|l|}
\hline Accession Number & $\mathbf{2 0 1 5 . 0 0 0 2 . 0 1 2 3}$ \\
\hline Title & {$[$ Leaving M] } \\
\hline Gauge & Super $\mathbf{m m m}$ \\
\hline Date Code & $\mathbf{1 9 8 0}$ \\
\hline Colour & Colour \\
\hline Film Polarity & Reversal \\
\hline Element & Camera Original \\
\hline Sound & Magnetic Stripe \\
\hline FPS & Unknown \\
\hline Aspect Ratio & $\mathbf{1 : 3 3 : 1}$ \\
\hline Length & $\mathbf{5 0 . 0}$ ft. \\
\hline Film Wind & B Wind \\
\hline $\begin{array}{l}\text { Stock } \\
\text { Manufacturer/Type }\end{array}$ & Eastman Kodak/ Ektachrome \\
\hline Base Type & Triacetate \\
\hline Splices & O \\
\hline Archival Status & Archival Element \\
\hline Overall Condition & Good \\
\hline
\end{tabular}




\begin{tabular}{|l|l|}
\hline Accession Number & $\mathbf{2 0 1 5 . 0 0 0 2 . 0 1 2 4}$ \\
\hline Title & [Untitled- Oct 31] \\
\hline Gauge & Super 8mm \\
\hline Date Code & $\mathbf{1 9 8 0}$ \\
\hline Colour & Colour \\
\hline Film Polarity & Reversal \\
\hline Element & Camera Original \\
\hline Sound & Magnetic Stripe \\
\hline FPS & Unknown \\
\hline Aspect Ratio & $\mathbf{1 : 3 3 : 1}$ \\
\hline Length & $\mathbf{5 0 . 0}$ ft. \\
\hline Film Wind & B Wind \\
\hline $\begin{array}{l}\text { Stock } \\
\text { Manufacturer/Type }\end{array}$ & Eastman Kodak/ Ektachrome \\
\hline Base Type & Triacetate \\
\hline Splices & O \\
\hline Archival Status & Archival Element \\
\hline Overall Condition & Good \\
\hline
\end{tabular}

\begin{tabular}{|l|l|}
\hline Accession Number & $\mathbf{2 0 1 5 . 0 0 0 2 . 0 1 2 5}$ \\
\hline Title & {$[$ Untitled- June] } \\
\hline Gauge & Super 8mm \\
\hline Date Code & 1980 \\
\hline Colour & Colour \\
\hline Film Polarity & Reversal \\
\hline Element & Camera Original \\
\hline Sound & Magnetic Stripe \\
\hline FPS & Unknown \\
\hline Aspect Ratio & $\mathbf{1 : 3 3 : 1}$ \\
\hline Length & $\mathbf{5 0 . 0} \mathrm{ft}$. \\
\hline Film Wind & B Wind \\
\hline $\begin{array}{l}\text { Stock } \\
\text { Manufacturer/Type }\end{array}$ & Eastman Kodak/ Kodachrome \\
\hline Base Type & Triacetate \\
\hline Splices & 0 \\
\hline Archival Status & Archival Element \\
\hline Overall Condition & Mediocre \\
\hline
\end{tabular}




\begin{tabular}{|l|l|}
\hline Accession Number & $\mathbf{2 0 1 5 . 0 0 0 2 . 0 1 2 6}$ \\
\hline Title & {$[$ Feb 20- T.V] } \\
\hline Gauge & Super 8mm \\
\hline Date Code & $\mathbf{1 9 8 0}$ \\
\hline Colour & Colour \\
\hline Film Polarity & Reversal \\
\hline Element & Camera Original \\
\hline Sound & Magnetic Stripe \\
\hline FPS & Unknown \\
\hline Aspect Ratio & $\mathbf{1 : 3 3 : 1}$ \\
\hline Length & $\mathbf{5 0 . 0}$ ft. \\
\hline Film Wind & B Wind \\
\hline $\begin{array}{l}\text { Stock } \\
\text { Manufacturer/Type }\end{array}$ & Eastman Kodak/ Ektachrome \\
\hline Base Type & Triacetate \\
\hline Splices & O \\
\hline Archival Status & Archival Element \\
\hline Overall Condition & Good \\
\hline
\end{tabular}

\begin{tabular}{|l|l|}
\hline Accession Number & $\mathbf{2 0 1 5 . 0 0 0 2 . 0 1 2 7}$ \\
\hline Title & [Rain- Truck Ride] \\
\hline Gauge & Super 8mm \\
\hline Date Code & $\mathbf{1 9 7 9}$ \\
\hline Colour & Colour \\
\hline Film Polarity & Reversal \\
\hline Element & Cut Original \\
\hline Sound & Magnetic Stripe \\
\hline FPS & Unknown \\
\hline Aspect Ratio & $\mathbf{1 : 3 3 : 1}$ \\
\hline Length & $\mathbf{5 0 . 0}$ ft. \\
\hline Film Wind & B Wind \\
\hline $\begin{array}{l}\text { Stock } \\
\text { Manufacturer/Type }\end{array}$ & Eastman Kodak/ Ektachrome \\
\hline Base Type & Triacetate \\
\hline Splices & $\mathbf{2}$ \\
\hline Archival Status & Archival Element \\
\hline Overall Condition & Mediocre \\
\hline
\end{tabular}




\begin{tabular}{|l|l|}
\hline Accession Number & $\mathbf{2 0 1 5 . 0 0 0 2 . 0 1 2 8}$ \\
\hline Title & {$[$ Melanka's Birthday Party] } \\
\hline Gauge & Super 8mm \\
\hline Date Code & $\mathbf{1 9 7 9}$ \\
\hline Colour & Colour \\
\hline Film Polarity & Reversal \\
\hline Element & Camera Original \\
\hline Sound & Magnetic Stripe \\
\hline FPS & Unknown \\
\hline Aspect Ratio & $\mathbf{1 : 3 3 : 1}$ \\
\hline Length & $\mathbf{5 0 . 0}$ ft. \\
\hline Film Wind & B Wind \\
\hline $\begin{array}{l}\text { Stock } \\
\text { Manufacturer/Type }\end{array}$ & Eastman Kodak/ Ektachrome \\
\hline Base Type & Triacetate \\
\hline Splices & O \\
\hline Archival Status & Archival Element \\
\hline Overall Condition & Mediocre \\
\hline
\end{tabular}

\begin{tabular}{|l|l|}
\hline Accession Number & 2015.0002 .0129 \\
\hline Title & {$[$ Snow Graffiti] } \\
\hline Gauge & Super 8mm \\
\hline Date Code & Unknown \\
\hline Colour & Colour \\
\hline Film Polarity & Reversal \\
\hline Element & Cut Original \\
\hline Sound & Magnetic Stripe \\
\hline FPS & Unknown \\
\hline Aspect Ratio & $\mathbf{1 : 3 3 : 1}$ \\
\hline Length & $\mathbf{5 0 . 0} \mathrm{ft}$. \\
\hline Film Wind & B Wind \\
\hline $\begin{array}{l}\text { Stock } \\
\text { Manufacturer/Type }\end{array}$ & Eastman Kodak/ Ektachrome \\
\hline Base Type & Triacetate \\
\hline Splices & $\mathbf{2}$ \\
\hline Archival Status & Archival Element \\
\hline Overall Condition & Poor \\
\hline
\end{tabular}




\begin{tabular}{|l|l|}
\hline Accession Number & $\mathbf{2 0 1 5 . 0 0 0 2 . 0 1 3 0}$ \\
\hline Title & [Untitled- March 81] \\
\hline Gauge & Super 8mm \\
\hline Date Code & $\mathbf{1 9 8 2}$ \\
\hline Colour & Colour \\
\hline Film Polarity & Reversal \\
\hline Element & Cut Original \\
\hline Sound & Magnetic Stripe \\
\hline FPS & Unknown \\
\hline Aspect Ratio & $\mathbf{1 : 3 3 : 1}$ \\
\hline Length & $\mathbf{5 0 . 0}$ ft. \\
\hline Film Wind & B Wind \\
\hline $\begin{array}{l}\text { Stock } \\
\text { Manufacturer/Type }\end{array}$ & Eastman Kodak/ Ektachrome \\
\hline Base Type & Triacetate \\
\hline Splices & $\mathbf{1}$ \\
\hline Archival Status & Archival Element \\
\hline Overall Condition & Good \\
\hline
\end{tabular}

\begin{tabular}{|l|l|}
\hline Accession Number & 2015.0002.0131 \\
\hline Title & [Untitled- April 82] \\
\hline Gauge & Super 8mm \\
\hline Date Code & $\mathbf{1 9 8 1}$ \\
\hline Colour & Colour \\
\hline Film Polarity & Reversal \\
\hline Element & Cut Original \\
\hline Sound & Magnetic Stripe \\
\hline FPS & Unknown \\
\hline Aspect Ratio & $\mathbf{1 : 3 3 : 1}$ \\
\hline Length & $\mathbf{5 0 . 0}$ ft. \\
\hline Film Wind & B Wind \\
\hline $\begin{array}{l}\text { Stock } \\
\text { Manufacturer/Type }\end{array}$ & Eastman Kodak/ Ektachrome \\
\hline Base Type & Triacetate \\
\hline Splices & $\mathbf{1}$ \\
\hline Archival Status & Archival Element \\
\hline Overall Condition & Mediocre \\
\hline
\end{tabular}




\begin{tabular}{|l|l|}
\hline Accession Number & $\mathbf{2 0 1 5 . 0 0 0 2 . 0 1 3 2}$ \\
\hline Title & {$[$ Letters \& Light] } \\
\hline Gauge & Super 8mm \\
\hline Date Code & $\mathbf{1 9 8 0}$ \\
\hline Colour & Colour \\
\hline Film Polarity & Reversal \\
\hline Element & Camera Original \\
\hline Sound & Magnetic Stripe \\
\hline FPS & Unknown \\
\hline Aspect Ratio & $\mathbf{1 : 3 3 : 1}$ \\
\hline Length & $\mathbf{5 0 . 0}$ ft. \\
\hline Film Wind & B Wind \\
\hline $\begin{array}{l}\text { Stock } \\
\text { Manufacturer/Type }\end{array}$ & Eastman Kodak/ Kodachrome \\
\hline Base Type & Triacetate \\
\hline Splices & O \\
\hline Archival Status & Archival Element \\
\hline Overall Condition & Poor \\
\hline
\end{tabular}

\begin{tabular}{|l|l|}
\hline Accession Number & $\mathbf{2 0 1 5 . 0 0 0 2 . 0 1 3 3}$ \\
\hline Title & {$[$ TV-May 82] } \\
\hline Gauge & Super 8mm \\
\hline Date Code & 1981 \\
\hline Colour & Colour \\
\hline Film Polarity & Reversal \\
\hline Element & Camera Original \\
\hline Sound & Magnetic Stripe \\
\hline FPS & Unknown \\
\hline Aspect Ratio & $\mathbf{1 : 3 3 : 1}$ \\
\hline Length & $\mathbf{5 0 . 0} \mathrm{ft}$. \\
\hline Film Wind & B Wind \\
\hline $\begin{array}{l}\text { Stock } \\
\text { Manufacturer/Type }\end{array}$ & Eastman Kodak/ Ektachrome \\
\hline Base Type & Triacetate \\
\hline Splices & 0 \\
\hline Archival Status & Archival Element \\
\hline Overall Condition & Good \\
\hline
\end{tabular}




\begin{tabular}{|l|l|}
\hline Accession Number & $\mathbf{2 0 1 5 . 0 0 0 2 . 0 1 3 4}$ \\
\hline Title & [Untitled] \\
\hline Gauge & Super 8mm \\
\hline Date Code & $\mathbf{1 9 8 2}$ \\
\hline Colour & Colour \\
\hline Film Polarity & Reversal \\
\hline Element & Camera Original \\
\hline Sound & Magnetic Stripe \\
\hline FPS & Unknown \\
\hline Aspect Ratio & $\mathbf{1 : 3 3 : 1}$ \\
\hline Length & $\mathbf{5 0 . 0}$ ft. \\
\hline Film Wind & B Wind \\
\hline $\begin{array}{l}\text { Stock } \\
\text { Manufacturer/Type }\end{array}$ & Eastman Kodak/ Ektachrome \\
\hline Base Type & Triacetate \\
\hline Splices & O \\
\hline Archival Status & Archival Element \\
\hline Overall Condition & Mediocre \\
\hline
\end{tabular}

\begin{tabular}{|l|l|}
\hline Accession Number & 2015.0002 .0135 \\
\hline Title & {$[\mathbf{8 6}$ Caundo] } \\
\hline Gauge & Super 8mm \\
\hline Date Code & 1985 \\
\hline Colour & Colour \\
\hline Film Polarity & Reversal \\
\hline Element & Camera Original \\
\hline Sound & Magnetic Stripe \\
\hline FPS & Unknown \\
\hline Aspect Ratio & $\mathbf{1 : 3 3 : 1}$ \\
\hline Length & $\mathbf{5 0 . 0} \mathrm{ft}$. \\
\hline Film Wind & B Wind \\
\hline $\begin{array}{l}\text { Stock } \\
\text { Manufacturer/Type }\end{array}$ & Eastman Kodak/ Kodachrome \\
\hline Base Type & Triacetate \\
\hline Splices & $\mathbf{0}$ \\
\hline Archival Status & Archival Element \\
\hline Overall Condition & Good \\
\hline
\end{tabular}




\begin{tabular}{|l|l|}
\hline Accession Number & $\mathbf{2 0 1 5 . 0 0 0 2 . 0 1 3 6}$ \\
\hline Title & [June 1981- Bands Performing] \\
\hline Gauge & Super 8mm \\
\hline Date Code & $\mathbf{1 9 8 0}$ \\
\hline Colour & Colour \\
\hline Film Polarity & Reversal \\
\hline Element & Camera Original \\
\hline Sound & Magnetic Stripe \\
\hline FPS & Unknown \\
\hline Aspect Ratio & $\mathbf{1 : 3 3 : 1}$ \\
\hline Length & $\mathbf{5 0 . 0}$ ft. \\
\hline Film Wind & Unknown \\
\hline $\begin{array}{l}\text { Stock } \\
\text { Manufacturer/Type }\end{array}$ & Eastman Kodak/ Ektachrome \\
\hline Base Type & Triacetate \\
\hline Splices & O \\
\hline Archival Status & Archival Element \\
\hline Overall Condition & Good \\
\hline
\end{tabular}

\begin{tabular}{|l|l|}
\hline Accession Number & $\mathbf{2 0 1 5 . 0 0 0 2 . 0 1 3 7}$ \\
\hline Title & {$[$ Oct 81- A's Party] } \\
\hline Gauge & Super 8mm \\
\hline Date Code & $\mathbf{1 9 8 1}$ \\
\hline Colour & Colour \\
\hline Film Polarity & Reversal \\
\hline Element & Camera Original \\
\hline Sound & Magnetic Stripe \\
\hline FPS & Unknown \\
\hline Aspect Ratio & $\mathbf{1 : 3 3 : 1}$ \\
\hline Length & $\mathbf{5 0 . 0}$ ft. \\
\hline Film Wind & B Wind \\
\hline $\begin{array}{l}\text { Stock } \\
\text { Manufacturer/Type }\end{array}$ & Eastman Kodak/ Ektachrome \\
\hline Base Type & Triacetate \\
\hline Splices & 0 \\
\hline Archival Status & Archival Element \\
\hline Overall Condition & Mediocre \\
\hline
\end{tabular}




\begin{tabular}{|l|l|}
\hline Accession Number & 2015.0002 .0138 \\
\hline Title & {$[$ Salon, Oct 81] } \\
\hline Gauge & Super 8mm \\
\hline Date Code & 1979 \\
\hline Colour & Colour \\
\hline Film Polarity & Reversal \\
\hline Element & Camera Original \\
\hline Sound & Magnetic Stripe \\
\hline FPS & Unknown \\
\hline Aspect Ratio & $\mathbf{1 : 3 3 : 1}$ \\
\hline Length & $\mathbf{5 0 . 0} \mathrm{ft}$. \\
\hline Film Wind & B Wind \\
\hline $\begin{array}{l}\text { Stock } \\
\text { Manufacturer/Type }\end{array}$ & Eastman Kodak/ Ektachrome \\
\hline Base Type & Triacetate \\
\hline Splices & $\mathbf{0}$ \\
\hline Archival Status & Archival Element \\
\hline Overall Condition & Good \\
\hline
\end{tabular}

\begin{tabular}{|l|l|}
\hline Accession Number & $\mathbf{2 0 1 5 . 0 0 0 2 . 0 1 3 9}$ \\
\hline Title & {$[$ Untitled] } \\
\hline Gauge & Super $8 \mathrm{~mm}$ \\
\hline Date Code & $\mathbf{1 9 8 2}$ \\
\hline Colour & Colour \\
\hline Film Polarity & Reversal \\
\hline Element & Cut Original \\
\hline Sound & Magnetic Stripe \\
\hline FPS & Unknown \\
\hline Aspect Ratio & $\mathbf{1 : 3 3 : 1}$ \\
\hline Length & $\mathbf{5 0 . 0}$ ft. \\
\hline Film Wind & Unknown \\
\hline $\begin{array}{l}\text { Stock } \\
\text { Manufacturer/Type }\end{array}$ & Eastman Kodak/ Kodachrome \\
\hline Base Type & Triacetate \\
\hline Splices & $\mathbf{3}$ \\
\hline Archival Status & Archival Element \\
\hline Overall Condition & Good \\
\hline
\end{tabular}




\begin{tabular}{|l|l|}
\hline Accession Number & $\mathbf{2 0 1 5 . 0 0 0 2 . 0 1 4 0}$ \\
\hline Title & {$[$ Shadow- March 31] } \\
\hline Gauge & Super 8mm \\
\hline Date Code & $\mathbf{1 9 8 0}$ \\
\hline Colour & Colour \\
\hline Film Polarity & Reversal \\
\hline Element & Camera Original \\
\hline Sound & Magnetic Stripe \\
\hline FPS & Unknown \\
\hline Aspect Ratio & $\mathbf{1 : 3 3 : 1}$ \\
\hline Length & $\mathbf{5 0 . 0}$ ft. \\
\hline Film Wind & Unknown \\
\hline $\begin{array}{l}\text { Stock } \\
\text { Manufacturer/Type }\end{array}$ & Eastman Kodak/ Kodachrome \\
\hline Base Type & Triacetate \\
\hline Splices & O \\
\hline Archival Status & Archival Element \\
\hline Overall Condition & Good \\
\hline
\end{tabular}

\begin{tabular}{|l|l|}
\hline Accession Number & $\mathbf{2 0 1 5 . 0 0 0 2 . 0 1 4 1}$ \\
\hline Title & {$[$ Montreal- NY] } \\
\hline Gauge & Super 8mm \\
\hline Date Code & $\mathbf{1 9 8 1}$ \\
\hline Colour & Colour \\
\hline Film Polarity & Reversal \\
\hline Element & Camera Original \\
\hline Sound & Magnetic Stripe \\
\hline FPS & Unknown \\
\hline Aspect Ratio & $\mathbf{1 : 3 3 : 1}$ \\
\hline Length & $\mathbf{5 0 . 0}$ ft. \\
\hline Film Wind & B Wind \\
\hline $\begin{array}{l}\text { Stock } \\
\text { Manufacturer/Type }\end{array}$ & Eastman Kodak/ Ektachrome \\
\hline Base Type & Triacetate \\
\hline Splices & O \\
\hline Archival Status & Archival Element \\
\hline Overall Condition & Good \\
\hline
\end{tabular}




\begin{tabular}{|l|l|}
\hline Accession Number & $\mathbf{2 0 1 5 . 0 0 0 2 . 0 1 4 2}$ \\
\hline Title & {$[$ Soundtrack/Cynthia's/ Fishing] } \\
\hline Gauge & Super $8 \mathrm{~mm}$ \\
\hline Date Code & $\mathbf{1 9 8 0}$ \\
\hline Colour & Colour \\
\hline Film Polarity & Reversal \\
\hline Element & Cut Original \\
\hline Sound & Magnetic Stripe \\
\hline FPS & Unknown \\
\hline Aspect Ratio & $\mathbf{1 : 3 3 : 1}$ \\
\hline Length & $\mathbf{5 0 . 0} \mathrm{ft}$. \\
\hline Film Wind & B Wind \\
\hline $\begin{array}{l}\text { Stock } \\
\text { Manufacturer/Type }\end{array}$ & Eastman Kodak/ Ektachrome \\
\hline Base Type & Triacetate \\
\hline Splices & $\mathbf{1}$ \\
\hline Archival Status & Archival Element \\
\hline Overall Condition & Mediocre \\
\hline
\end{tabular}

\begin{tabular}{|l|l|}
\hline Accession Number & $\mathbf{2 0 1 5 . 0 0 0 2 . 0 1 4 3}$ \\
\hline Title & {$[$ Every 15 Minutes] } \\
\hline Gauge & Super 8mm \\
\hline Date Code & $\mathbf{1 9 8 1}$ \\
\hline Colour & Colour \\
\hline Film Polarity & Reversal \\
\hline Element & Camera Original \\
\hline Sound & Magnetic Stripe \\
\hline FPS & Unknown \\
\hline Aspect Ratio & $\mathbf{1 : 3 3 : 1}$ \\
\hline Length & $\mathbf{5 0 . 0}$ ft. \\
\hline Film Wind & Unknown \\
\hline $\begin{array}{l}\text { Stock } \\
\text { Manufacturer/Type }\end{array}$ & Eastman Kodak/ Ektachrome \\
\hline Base Type & Triacetate \\
\hline Splices & 0 \\
\hline Archival Status & Archival Element \\
\hline Overall Condition & Poor \\
\hline
\end{tabular}




\begin{tabular}{|l|l|}
\hline Accession Number & $\mathbf{2 0 1 5 . 0 0 0 2 . 0 1 4 4}$ \\
\hline Title & [Do Da Gig] \\
\hline Gauge & Super 8mm \\
\hline Date Code & 1979 \\
\hline Colour & Colour \\
\hline Film Polarity & Reversal \\
\hline Element & Camera Original \\
\hline Sound & Magnetic Stripe \\
\hline FPS & Unknown \\
\hline Aspect Ratio & $1: 33: 1$ \\
\hline Length & $\mathbf{5 0 . 0}$ ft. \\
\hline Film Wind & B Wind \\
\hline $\begin{array}{l}\text { Stock } \\
\text { Manufacturer/Type }\end{array}$ & Eastman Kodak/ Ektachrome \\
\hline Base Type & Triacetate \\
\hline Splices & O \\
\hline Archival Status & Archival Element \\
\hline Overall Condition & Good \\
\hline
\end{tabular}

\begin{tabular}{|l|l|}
\hline Accession Number & $\mathbf{2 0 1 5 . 0 0 0 2 . 0 1 4 5}$ \\
\hline Title & {$[$ Salon Haircuts/ Next Day] } \\
\hline Gauge & Super 8mm \\
\hline Date Code & $\mathbf{1 9 8 0}$ \\
\hline Colour & Colour \\
\hline Film Polarity & Reversal \\
\hline Element & Camera Original \\
\hline Sound & Magnetic Stripe \\
\hline FPS & Unknown \\
\hline Aspect Ratio & $\mathbf{1 : 3 3 : 1}$ \\
\hline Length & $\mathbf{5 0 . 0}$ ft. \\
\hline Film Wind & Unknown \\
\hline $\begin{array}{l}\text { Stock } \\
\text { Manufacturer/Type }\end{array}$ & Eastman Kodak/ Ektachrome \\
\hline Base Type & Triacetate \\
\hline Splices & 0 \\
\hline Archival Status & Archival Element \\
\hline Overall Condition & Good \\
\hline
\end{tabular}




\begin{tabular}{|l|l|}
\hline Accession Number & $\mathbf{2 0 1 5 . 0 0 0 2 . 0 1 4 6}$ \\
\hline Title & {$[$ Performance School- July 30] } \\
\hline Gauge & Super 8mm \\
\hline Date Code & $\mathbf{1 9 8 1}$ \\
\hline Colour & Colour \\
\hline Film Polarity & Reversal \\
\hline Element & Camera Original \\
\hline Sound & Magnetic Stripe \\
\hline FPS & Unknown \\
\hline Aspect Ratio & $\mathbf{1 : 3 3 : 1}$ \\
\hline Length & $\mathbf{5 0 . 0}$ ft. \\
\hline Film Wind & Unknown \\
\hline $\begin{array}{l}\text { Stock } \\
\text { Manufacturer/Type }\end{array}$ & Eastman Kodak/ Ektachrome \\
\hline Base Type & Triacetate \\
\hline Splices & O \\
\hline Archival Status & Archival Element \\
\hline Overall Condition & Good \\
\hline
\end{tabular}

\begin{tabular}{|l|l|}
\hline Accession Number & $\mathbf{2 0 1 5 . 0 0 0 2 . 0 1 4 7}$ \\
\hline Title & {$[$ Bar in Little Italy- June 1981] } \\
\hline Gauge & Super 8mm \\
\hline Date Code & $\mathbf{1 9 8 0}$ \\
\hline Colour & Colour \\
\hline Film Polarity & Reversal \\
\hline Element & Camera Original \\
\hline Sound & Mag Stripe \\
\hline FPS & Unknown \\
\hline Aspect Ratio & $\mathbf{1 : 3 3 : 1}$ \\
\hline Length & $\mathbf{5 0 . 0}$ ft. \\
\hline Film Wind & B Wind \\
\hline $\begin{array}{l}\text { Stock } \\
\text { Manufacturer/Type }\end{array}$ & Eastman Kodak/ Ektachrome \\
\hline Base Type & Triacetate \\
\hline Splices & O \\
\hline Archival Status & Archival Element \\
\hline Overall Condition & Mediocre \\
\hline
\end{tabular}




\begin{tabular}{|l|l|}
\hline Accession Number & $\mathbf{2 0 1 5 . 0 0 0 2 . 0 1 4 8}$ \\
\hline Title & {$[$ Chinatown/Fluorescent Lights- Oct 1981] } \\
\hline Gauge & Super 8mm \\
\hline Date Code & $\mathbf{1 9 8 1}$ \\
\hline Colour & Colour \\
\hline Film Polarity & Reversal \\
\hline Element & Cut Original \\
\hline Sound & Magnetic Stripe \\
\hline FPS & Unknown \\
\hline Aspect Ratio & $\mathbf{1 : 3 3 : 1}$ \\
\hline Length & $\mathbf{5 0 . 0}$ ft. \\
\hline Film Wind & B Wind \\
\hline $\begin{array}{l}\text { Stock } \\
\text { Manufacturer/Type }\end{array}$ & Eastman Kodak/ Ektachrome \\
\hline Base Type & Triacetate \\
\hline Splices & $\mathbf{2}$ \\
\hline Archival Status & Archival Element \\
\hline Overall Condition & Good \\
\hline
\end{tabular}

\begin{tabular}{|l|l|}
\hline Accession Number & $\mathbf{2 0 1 5 . 0 0 0 2 . 0 1 4 9}$ \\
\hline Title & {$[$ Untitled- March 1982] } \\
\hline Gauge & Super 8mm \\
\hline Date Code & 1981 \\
\hline Colour & Colour \\
\hline Film Polarity & Reversal \\
\hline Element & Cut Original \\
\hline Sound & Magnatic Stripe \\
\hline FPS & Unknown \\
\hline Aspect Ratio & $\mathbf{1 : 3 3 : 1}$ \\
\hline Length & $\mathbf{5 0 . 0}$ ft. \\
\hline Film Wind & B Wind \\
\hline $\begin{array}{l}\text { Stock } \\
\text { Manufacturer/Type }\end{array}$ & Eastman Kodak/ Ektachrome \\
\hline Base Type & Triacetate \\
\hline Splices & 1 \\
\hline Archival Status & Archival Element \\
\hline Overall Condition & Mediocre \\
\hline
\end{tabular}




\begin{tabular}{|l|l|}
\hline Accession Number & $\mathbf{2 0 1 5 . 0 0 0 2 . 0 1 5 0}$ \\
\hline Title & {$[$ Fire on Bowery- Sept 11, 1980] } \\
\hline Gauge & Super 8mm \\
\hline Date Code & $\mathbf{1 9 8 0}$ \\
\hline Colour & Colour \\
\hline Film Polarity & Reversal \\
\hline Element & Cut Original \\
\hline Sound & Magnetic Stripe \\
\hline FPS & Unknown \\
\hline Aspect Ratio & $\mathbf{1 : 3 3 : 1}$ \\
\hline Length & $\mathbf{5 0 . 0}$ ft. \\
\hline Film Wind & Unknown \\
\hline $\begin{array}{l}\text { Stock } \\
\text { Manufacturer/Type }\end{array}$ & Eastman Kodak/ Ektachrome \\
\hline Base Type & Triacetate \\
\hline Splices & $\mathbf{2}$ \\
\hline Archival Status & Archival Element \\
\hline Overall Condition & Good \\
\hline
\end{tabular}

\begin{tabular}{|l|l|}
\hline Accession Number & $\mathbf{2 0 1 5 . 0 0 0 2 . 0 1 5 1}$ \\
\hline Title & {$[$ Arleen Schloss- March 1982] } \\
\hline Gauge & Super 8mm \\
\hline Date Code & $\mathbf{1 9 7 9}$ \\
\hline Colour & Colour \\
\hline Film Polarity & Reversal \\
\hline Element & Cut Original \\
\hline Sound & Magnetic Stripe \\
\hline FPS & Unknown \\
\hline Aspect Ratio & $\mathbf{1 : 3 3 : 1}$ \\
\hline Length & $\mathbf{5 0 . 0}$ ft. \\
\hline Film Wind & Unknown \\
\hline $\begin{array}{l}\text { Stock } \\
\text { Manufacturer/Type }\end{array}$ & Eastman Kodak/ Ektachrome \\
\hline Base Type & Triacetate \\
\hline Splices & $\mathbf{1}$ \\
\hline Archival Status & Archival Element \\
\hline Overall Condition & Good \\
\hline
\end{tabular}




\begin{tabular}{|l|l|}
\hline Accession Number & $\mathbf{2 0 1 5 . 0 0 0 2 . 0 1 5 2}$ \\
\hline Title & {$[$ Party- Oct 1980] } \\
\hline Gauge & Super 8mm \\
\hline Date Code & $\mathbf{1 9 7 9}$ \\
\hline Colour & Colour \\
\hline Film Polarity & Reversal \\
\hline Element & Camera Original \\
\hline Sound & Magnetic Stripe \\
\hline FPS & Unknown \\
\hline Aspect Ratio & $\mathbf{1 : 3 3 : 1}$ \\
\hline Length & $\mathbf{5 0 . 0}$ ft. \\
\hline Film Wind & Unknown \\
\hline $\begin{array}{l}\text { Stock } \\
\text { Manufacturer/Type }\end{array}$ & Eastman Kodak/ Ektachrome \\
\hline Base Type & Triacetate \\
\hline Splices & O \\
\hline Archival Status & Archival Element \\
\hline Overall Condition & Good \\
\hline
\end{tabular}

\begin{tabular}{|l|l|}
\hline Accession Number & $\mathbf{2 0 1 5 . 0 0 0 2 . 0 1 5 3}$ \\
\hline Title & {$[$ Arleen Schloss/A's- July 1980] } \\
\hline Gauge & Super 8mm \\
\hline Date Code & 1979 \\
\hline Colour & Colour \\
\hline Film Polarity & Reversal \\
\hline Element & Cut Original \\
\hline Sound & Magnetic Stripe \\
\hline FPS & Unknown \\
\hline Aspect Ratio & $\mathbf{1 : 3 3 : 1}$ \\
\hline Length & $\mathbf{5 0 . 0} \mathrm{ft}$. \\
\hline Film Wind & Unknown \\
\hline $\begin{array}{l}\text { Stock } \\
\text { Manufacturer/Type }\end{array}$ & Eastman Kodak/ Kodachrome \\
\hline Base Type & Triacetate \\
\hline Splices & $\mathbf{1}$ \\
\hline Archival Status & Archival Element \\
\hline Overall Condition & Poor \\
\hline
\end{tabular}




\begin{tabular}{|l|l|}
\hline Accession Number & $\mathbf{2 0 1 5 . 0 0 0 2 . 0 1 5 4}$ \\
\hline Title & {$[\mathbf{8 6 -}$-Caundo] } \\
\hline Gauge & Super $\mathbf{m m m}$ \\
\hline Date Code & $\mathbf{1 9 8 5}$ \\
\hline Colour & Colour \\
\hline Film Polarity & Reversal \\
\hline Element & Camera Original \\
\hline Sound & Magnetic Stripe \\
\hline FPS & Unknown \\
\hline Aspect Ratio & $\mathbf{1 : 3 3 : 1}$ \\
\hline Length & $\mathbf{5 0 . 0}$ ft. \\
\hline Film Wind & B Wind \\
\hline $\begin{array}{l}\text { Stock } \\
\text { Manufacturer/Type }\end{array}$ & Eastman Kodak/ Kodachrome \\
\hline Base Type & Triacetate \\
\hline Splices & O \\
\hline Archival Status & Archival Element \\
\hline Overall Condition & Good \\
\hline
\end{tabular}

\begin{tabular}{|l|l|}
\hline Accession Number & $\mathbf{2 0 1 5 . 0 0 0 2 . 0 1 5 5}$ \\
\hline Title & {$[$ Untitled- May 1981] } \\
\hline Gauge & Super 8mm \\
\hline Date Code & $\mathbf{1 9 8 0}$ \\
\hline Colour & Colour \\
\hline Film Polarity & Reversal \\
\hline Element & Camera Original \\
\hline Sound & Magnetic Stripe \\
\hline FPS & Unknown \\
\hline Aspect Ratio & $\mathbf{1 : 3 3 : 1}$ \\
\hline Length & $\mathbf{5 0 . 0}$ ft. \\
\hline Film Wind & Unknown \\
\hline $\begin{array}{l}\text { Stock } \\
\text { Manufacturer/Type }\end{array}$ & Eastman Kodak/ Ektachrome \\
\hline Base Type & Triacetate \\
\hline Splices & O \\
\hline Archival Status & Archival Element \\
\hline Overall Condition & Good \\
\hline
\end{tabular}




\begin{tabular}{|l|l|}
\hline Accession Number & 2015.0002 .0156 \\
\hline Title & {$[$ ABC News/Color Xerox- Dec 1980] } \\
\hline Gauge & Super 8mm \\
\hline Date Code & 1980 \\
\hline Colour & Colour \\
\hline Film Polarity & Reversal \\
\hline Element & Cut Original \\
\hline Sound & Magnetic Stripe \\
\hline FPS & Unknown \\
\hline Aspect Ratio & $\mathbf{1 : 3 3 : 1}$ \\
\hline Length & $\mathbf{5 0 . 0} \mathrm{ft}$. \\
\hline Film Wind & B Wind \\
\hline $\begin{array}{l}\text { Stock } \\
\text { Manufacturer/Type }\end{array}$ & Eastman Kodak/ Ektachrome \\
\hline Base Type & Triacetate \\
\hline Splices & $\mathbf{3}$ \\
\hline Archival Status & Archival Element \\
\hline Overall Condition & Poor \\
\hline
\end{tabular}

\begin{tabular}{|l|l|}
\hline Accession Number & 2015.0002.0157 \\
\hline Title & {$[$ PS 161/ CAC- 1984] } \\
\hline Gauge & Super 8mm \\
\hline Date Code & 1983 \\
\hline Colour & Colour \\
\hline Film Polarity & Reversal \\
\hline Element & Cut Original \\
\hline Sound & Silent \\
\hline FPS & Unknown \\
\hline Aspect Ratio & $\mathbf{1 : 3 3 : 1}$ \\
\hline Length & $\mathbf{5 0 . 0} \mathrm{ft}$. \\
\hline Film Wind & B Wind \\
\hline $\begin{array}{l}\text { Stock } \\
\text { Manufacturer/Type }\end{array}$ & Eastman Kodak/ Kodachrome \\
\hline Base Type & Triacetate \\
\hline Splices & 0 \\
\hline Archival Status & Archival Element \\
\hline Overall Condition & Good \\
\hline
\end{tabular}




\begin{tabular}{|l|l|}
\hline Accession Number & 2015.0002 .0158 \\
\hline Title & {$[$ Sunday/Plum Beach- 1981] } \\
\hline Gauge & Super 8mm \\
\hline Date Code & 1981 \\
\hline Colour & Colour \\
\hline Film Polarity & Reversal \\
\hline Element & Cut Original \\
\hline Sound & Magnetic Stripe \\
\hline FPS & Unknown \\
\hline Aspect Ratio & $1: 33: 1$ \\
\hline Length & $\mathbf{5 0 . 0} \mathrm{ft}$. \\
\hline Film Wind & B Wind \\
\hline $\begin{array}{l}\text { Stock } \\
\text { Manufacturer/Type }\end{array}$ & Eastman Kodak/ Ektachrome \\
\hline Base Type & Triacetate \\
\hline Splices & 1 \\
\hline Archival Status & Archival Element \\
\hline Overall Condition & Good \\
\hline
\end{tabular}

\begin{tabular}{|l|l|}
\hline Accession Number & $\mathbf{2 0 1 5 . 0 0 0 2 . 0 1 5 9}$ \\
\hline Title & {$[$ Untitled] } \\
\hline Gauge & Super $8 \mathrm{~mm}$ \\
\hline Date Code & $\mathbf{1 9 8 4}$ \\
\hline Colour & Colour \\
\hline Film Polarity & Reversal \\
\hline Element & Camera Original \\
\hline Sound & Magnetic Stripe \\
\hline FPS & Unknown \\
\hline Aspect Ratio & $\mathbf{1 : 3 3 : 1}$ \\
\hline Length & $\mathbf{5 0 . 0}$ ft. \\
\hline Film Wind & B Wind \\
\hline $\begin{array}{l}\text { Stock } \\
\text { Manufacturer/Type }\end{array}$ & Eastman Kodak/ Kodachrome \\
\hline Base Type & Triacetate \\
\hline Splices & O \\
\hline Archival Status & Archival Element \\
\hline Overall Condition & Excellent \\
\hline
\end{tabular}




\begin{tabular}{|l|l|}
\hline Accession Number & $\mathbf{2 0 1 5 . 0 0 0 2 . 0 1 6 0}$ \\
\hline Title & {$[$ A-Outside/TV Color] } \\
\hline Gauge & Super 8mm \\
\hline Date Code & Unknown \\
\hline Colour & Colour \\
\hline Film Polarity & Reversal \\
\hline Element & Camera Original \\
\hline Sound & Magnetic Stripe \\
\hline FPS & Unknown \\
\hline Aspect Ratio & $\mathbf{1 : 3 3 : 1}$ \\
\hline Length & $\mathbf{5 0 . 0}$ ft. \\
\hline Film Wind & B Wind \\
\hline $\begin{array}{l}\text { Stock } \\
\text { Manufacturer/Type }\end{array}$ & Eastman Kodak/ Ektachrome \\
\hline Base Type & Triacetate \\
\hline Splices & O \\
\hline Archival Status & Archival Element \\
\hline Overall Condition & Good \\
\hline
\end{tabular}

\begin{tabular}{|c|c|}
\hline Accession Number & 2015.0002.0161 \\
\hline Title & {$\left[42^{\text {nd }}\right.$ St.- Oct 81] } \\
\hline Gauge & Super $8 \mathrm{~mm}$ \\
\hline Date Code & 1981 \\
\hline Colour & Colour \\
\hline Film Polarity & Reversal \\
\hline Element & Camera Original \\
\hline Sound & Magnetic Stripe \\
\hline FPS & Unknown \\
\hline Aspect Ratio & 1:33:1 \\
\hline Length & $50.0 \mathrm{ft}$. \\
\hline Film Wind & B Wind \\
\hline $\begin{array}{l}\text { Stock } \\
\text { Manufacturer/Type }\end{array}$ & Eastman Kodak/ Kodachrome \\
\hline Base Type & Triacetate \\
\hline Splices & 0 \\
\hline Archival Status & Archival Element \\
\hline Overall Condition & Good \\
\hline
\end{tabular}




\begin{tabular}{|l|l|}
\hline Accession Number & $\mathbf{2 0 1 5 . 0 0 0 2 . 0 1 6 2}$ \\
\hline Title & [Untitled- Jan 82] \\
\hline Gauge & Super 8mm \\
\hline Date Code & $\mathbf{1 9 8 1}$ \\
\hline Colour & Colour \\
\hline Film Polarity & Reversal \\
\hline Element & Camera Original \\
\hline Sound & Magnetic Stripe \\
\hline FPS & Unknown \\
\hline Aspect Ratio & $\mathbf{1 : 3 3 : 1}$ \\
\hline Length & $\mathbf{5 0 . 0}$ ft. \\
\hline Film Wind & B Wind \\
\hline $\begin{array}{l}\text { Stock } \\
\text { Manufacturer/Type }\end{array}$ & Eastman Kodak/ Ektachrome \\
\hline Base Type & Triacetate \\
\hline Splices & O \\
\hline Archival Status & Archival Element \\
\hline Overall Condition & Mediocre \\
\hline
\end{tabular}

\begin{tabular}{|l|l|}
\hline Accession Number & 2015.0002 .0163 \\
\hline Title & {$[$ The Space- July 26, 1980] } \\
\hline Gauge & Super 8mm \\
\hline Date Code & 1979 \\
\hline Colour & Colour \\
\hline Film Polarity & Reversal \\
\hline Element & Camera Original \\
\hline Sound & Magnetic Stripe \\
\hline FPS & Unknown \\
\hline Aspect Ratio & $\mathbf{1 : 3 3 : 1}$ \\
\hline Length & $\mathbf{5 0 . 0} \mathrm{ft}$. \\
\hline Film Wind & B Wind \\
\hline $\begin{array}{l}\text { Stock } \\
\text { Manufacturer/Type }\end{array}$ & Eastman Kodak/ Ektachrome \\
\hline Base Type & Triacetate \\
\hline Splices & 0 \\
\hline Archival Status & Archival Element \\
\hline Overall Condition & Mediocre \\
\hline
\end{tabular}




\begin{tabular}{|l|l|}
\hline Accession Number & $\mathbf{2 0 1 5 . 0 0 0 2 . 0 1 6 4}$ \\
\hline Title & [Untitled- June 81] \\
\hline Gauge & Super 8mm \\
\hline Date Code & $\mathbf{1 9 8 0}$ \\
\hline Colour & Colour \\
\hline Film Polarity & Reversal \\
\hline Element & Camera Original \\
\hline Sound & Magnetic Stripe \\
\hline FPS & Unknown \\
\hline Aspect Ratio & $\mathbf{1 : 3 3 : 1}$ \\
\hline Length & $\mathbf{5 0 . 0}$ ft. \\
\hline Film Wind & B Wind \\
\hline $\begin{array}{l}\text { Stock } \\
\text { Manufacturer/Type }\end{array}$ & Eastman Kodak/ Ektachrome \\
\hline Base Type & Triacetate \\
\hline Splices & O \\
\hline Archival Status & Archival Element \\
\hline Overall Condition & Good \\
\hline
\end{tabular}

\begin{tabular}{|l|l|}
\hline Accession Number & 2015.0002 .0165 \\
\hline Title & {$[$ The Dinner- March] } \\
\hline Gauge & Super 8mm \\
\hline Date Code & 1980 \\
\hline Colour & Colour \\
\hline Film Polarity & Reversal \\
\hline Element & Camera Original \\
\hline Sound & Magnetic Stripe \\
\hline FPS & Unknown \\
\hline Aspect Ratio & $\mathbf{1 : 3 3 : 1}$ \\
\hline Length & $\mathbf{5 0 . 0} \mathrm{ft}$. \\
\hline Film Wind & B Wind \\
\hline $\begin{array}{l}\text { Stock } \\
\text { Manufacturer/Type }\end{array}$ & Eastman Kodak/ Ektachrome \\
\hline Base Type & Triacetate \\
\hline Splices & 0 \\
\hline Archival Status & Archival Element \\
\hline Overall Condition & Good \\
\hline
\end{tabular}




\begin{tabular}{|l|l|}
\hline Accession Number & 2015.0002 .0166 \\
\hline Title & [Uptown Streets/ Sur Rodney's/Construction Sites- 1981] \\
\hline Gauge & Super 8mm \\
\hline Date Code & 1980 \\
\hline Colour & Colour \\
\hline Film Polarity & Reversal \\
\hline Element & Cut Original \\
\hline Sound & Magnetic Stripe \\
\hline FPS & Unknown \\
\hline Aspect Ratio & $\mathbf{1 : 3 3 : 1}$ \\
\hline Length & $\mathbf{5 0 . 0} \mathrm{ft}$. \\
\hline Film Wind & B Wind \\
\hline $\begin{array}{l}\text { Stock } \\
\text { Manufacturer/Type }\end{array}$ & Eastman Kodak/ Ektachrome \\
\hline Base Type & Triacetate \\
\hline Splices & 1 \\
\hline Archival Status & Archival Element \\
\hline Overall Condition & Good \\
\hline
\end{tabular}

\begin{tabular}{|l|l|}
\hline Accession Number & $\mathbf{2 0 1 5 . 0 0 0 2 . 0 1 6 7}$ \\
\hline Title & {$[$ Rain on the Bowery- March 81] } \\
\hline Gauge & Super 8mm \\
\hline Date Code & $\mathbf{1 9 8 0}$ \\
\hline Colour & Colour \\
\hline Film Polarity & Reversal \\
\hline Element & Camera Original \\
\hline Sound & Magnetic Stripe \\
\hline FPS & Unknown \\
\hline Aspect Ratio & $\mathbf{1 : 3 3 : 1}$ \\
\hline Length & $\mathbf{5 0 . 0}$ ft. \\
\hline Film Wind & B Wind \\
\hline $\begin{array}{l}\text { Stock } \\
\text { Manufacturer/Type }\end{array}$ & Eastman Kodak/ Kodachrome \\
\hline Base Type & Triacetate \\
\hline Splices & 0 \\
\hline Archival Status & Archival Element \\
\hline Overall Condition & Good \\
\hline
\end{tabular}




\begin{tabular}{|l|l|}
\hline Accession Number & $\mathbf{2 0 1 5 . 0 0 0 2 . 0 1 0 6 8}$ \\
\hline Title & Miss U \\
\hline Gauge & Super 8mm \\
\hline Date Code & 1987 \\
\hline Colour & Colour \\
\hline Film Polarity & Reversal \\
\hline Element & Camera Original \\
\hline Sound & Magnetic Stripe \\
\hline FPS & Unknown \\
\hline Aspect Ratio & $\mathbf{1 : 3 3 : 1}$ \\
\hline Length & $\mathbf{5 0 . 0}$ ft. \\
\hline Film Wind & B Wind \\
\hline $\begin{array}{l}\text { Stock } \\
\text { Manufacturer/Type }\end{array}$ & Eastman Kodak/ Kodachrome \\
\hline Base Type & Triacetate \\
\hline Splices & O \\
\hline Archival Status & Archival Element \\
\hline Overall Condition & Good \\
\hline
\end{tabular}

\begin{tabular}{|l|l|}
\hline Accession Number & 2015.0002 .0169 \\
\hline Title & {$[$ Montreal- February] } \\
\hline Gauge & Super 8mm \\
\hline Date Code & Unknown \\
\hline Colour & Colour \\
\hline Film Polarity & Reversal \\
\hline Element & Camera Original \\
\hline Sound & Magnetic Stripe \\
\hline FPS & Unknown \\
\hline Aspect Ratio & $\mathbf{1 : 3 3 : 1}$ \\
\hline Length & $\mathbf{5 0 . 0} \mathrm{ft}$. \\
\hline Film Wind & B Wind \\
\hline $\begin{array}{l}\text { Stock } \\
\text { Manufacturer/Type }\end{array}$ & Eastman Kodak/ Ektachrome \\
\hline Base Type & Triacetate \\
\hline Splices & 0 \\
\hline Archival Status & Archival Element \\
\hline Overall Condition & Mediocre \\
\hline
\end{tabular}




\begin{tabular}{|l|l|}
\hline Accession Number & $\mathbf{2 0 1 5 . 0 0 0 2 . 0 1 7 0}$ \\
\hline Title & {$[$ Stanley's/ Mirage Ranch] } \\
\hline Gauge & Super 8mm \\
\hline Date Code & Unknown \\
\hline Colour & Colour \\
\hline Film Polarity & Reversal \\
\hline Element & Camera Original \\
\hline Sound & Magnetic Stripe \\
\hline FPS & Unknown \\
\hline Aspect Ratio & $\mathbf{1 : 3 3 : 1}$ \\
\hline Length & $\mathbf{5 0 . 0}$ ft. \\
\hline Film Wind & B Wind \\
\hline $\begin{array}{l}\text { Stock } \\
\text { Manufacturer/Type }\end{array}$ & Eastman Kodak/ Ektachrome \\
\hline Base Type & Triacetate \\
\hline Splices & O \\
\hline Archival Status & Archival Element \\
\hline Overall Condition & Mediocre \\
\hline
\end{tabular}

\begin{tabular}{|l|l|}
\hline Accession Number & 2015.0002.0171 \\
\hline Title & {$[$ Outside the Plaza/Fishing] } \\
\hline Gauge & Super 8mm \\
\hline Date Code & Unknown \\
\hline Colour & Colour \\
\hline Film Polarity & Reversal \\
\hline Element & Camera Original \\
\hline Sound & Magnetic Stripe \\
\hline FPS & Unknown \\
\hline Aspect Ratio & $\mathbf{1 : 3 3 : 1}$ \\
\hline Length & $\mathbf{5 0 . 0}$ ft. \\
\hline Film Wind & B Wind \\
\hline $\begin{array}{l}\text { Stock } \\
\text { Manufacturer/Type }\end{array}$ & Eastman Kodak/ Ektachrome \\
\hline Base Type & Triacetate \\
\hline Splices & 0 \\
\hline Archival Status & Archival Element \\
\hline Overall Condition & Mediocre \\
\hline
\end{tabular}




\begin{tabular}{|l|l|}
\hline Accession Number & $\mathbf{2 0 1 5 . 0 0 0 2 . 0 1 7 2}$ \\
\hline Title & [Untitled- March 31] \\
\hline Gauge & Super 8mm \\
\hline Date Code & $\mathbf{1 9 8 0}$ \\
\hline Colour & Colour \\
\hline Film Polarity & Reversal \\
\hline Element & Camera Original \\
\hline Sound & Magnetic Stripe \\
\hline FPS & Unknown \\
\hline Aspect Ratio & $\mathbf{1 : 3 3 : 1}$ \\
\hline Length & $\mathbf{5 0 . 0}$ ft. \\
\hline Film Wind & B Wind \\
\hline $\begin{array}{l}\text { Stock } \\
\text { Manufacturer/Type }\end{array}$ & Eastman Kodak/ Ektachrome \\
\hline Base Type & Triacetate \\
\hline Splices & O \\
\hline Archival Status & Archival Element \\
\hline Overall Condition & Good \\
\hline
\end{tabular}

\begin{tabular}{|l|l|}
\hline Accession Number & $\mathbf{2 0 1 5 . 0 0 0 2 . 0 1 7 3}$ \\
\hline Title & [Untitled- Dec 81] \\
\hline Gauge & Super 8mm \\
\hline Date Code & $\mathbf{1 9 8 0}$ \\
\hline Colour & Colour \\
\hline Film Polarity & Reversal \\
\hline Element & Camera Original \\
\hline Sound & Magnetic Stripe \\
\hline FPS & Unknown \\
\hline Aspect Ratio & $\mathbf{1 : 3 3 : 1}$ \\
\hline Length & $\mathbf{5 0 . 0}$ ft. \\
\hline Film Wind & B Wind \\
\hline $\begin{array}{l}\text { Stock } \\
\text { Manufacturer/Type }\end{array}$ & Eastman Kodak/ Ektachrome \\
\hline Base Type & Triacetate \\
\hline Splices & O \\
\hline Archival Status & Archival Element \\
\hline Overall Condition & Good \\
\hline
\end{tabular}




\begin{tabular}{|l|l|}
\hline Accession Number & $\mathbf{2 0 1 5 . 0 0 0 2 . 0 1 7 4}$ \\
\hline Title & [Untitled- July 1980] \\
\hline Gauge & Super 8mm \\
\hline Date Code & $\mathbf{1 9 7 9}$ \\
\hline Colour & Colour \\
\hline Film Polarity & Reversal \\
\hline Element & Camera Original \\
\hline Sound & Magnetic Stripe \\
\hline FPS & Unknown \\
\hline Aspect Ratio & $\mathbf{1 : 3 3 : 1}$ \\
\hline Length & $\mathbf{5 0 . 0}$ ft. \\
\hline Film Wind & B Wind \\
\hline $\begin{array}{l}\text { Stock } \\
\text { Manufacturer/Type }\end{array}$ & Eastman Kodak/ Ektachrome \\
\hline Base Type & Triacetate \\
\hline Splices & O \\
\hline Archival Status & Archival Element \\
\hline Overall Condition & Good \\
\hline
\end{tabular}

\begin{tabular}{|l|l|}
\hline Accession Number & $\mathbf{2 0 1 5 . 0 0 0 2 . 0 1 7 5}$ \\
\hline Title & {$[$ MoMA Performance- Oct 80] } \\
\hline Gauge & Super 8mm \\
\hline Date Code & 1980 \\
\hline Colour & Colour \\
\hline Film Polarity & Reversal \\
\hline Element & Camera Original \\
\hline Sound & Magnetic Stripe \\
\hline FPS & Unknown \\
\hline Aspect Ratio & $\mathbf{1 : 3 3 : 1}$ \\
\hline Length & $\mathbf{5 0 . 0} \mathrm{ft}$. \\
\hline Film Wind & B Wind \\
\hline $\begin{array}{l}\text { Stock } \\
\text { Manufacturer/Type }\end{array}$ & Eastman Kodak/ Ektachrome \\
\hline Base Type & Triacetate \\
\hline Splices & 0 \\
\hline Archival Status & Archival Element \\
\hline Overall Condition & Mediocre \\
\hline
\end{tabular}

- 2015.0002.0176 was not a part of this particular box of films. 


\begin{tabular}{|l|l|}
\hline Accession Number & $\mathbf{2 0 1 5 . 0 0 0 2 . 0 1 7 7}$ \\
\hline Title & {$[$ Untitled] } \\
\hline Gauge & Super 8mm \\
\hline Date Code & $\mathbf{1 9 8 0}$ \\
\hline Colour & Colour \\
\hline Film Polarity & Reversal \\
\hline Element & Cut Original \\
\hline Sound & Magnetic Stripe \\
\hline FPS & Unknown \\
\hline Aspect Ratio & $\mathbf{1 : 3 3 : 1}$ \\
\hline Length & $\mathbf{5 0 . 0} \mathrm{ft}$. \\
\hline Film Wind & B Wind \\
\hline $\begin{array}{l}\text { Stock } \\
\text { Manufacturer/Type }\end{array}$ & Eastman Kodak/ Ektachrome \\
\hline Base Type & Triacetate \\
\hline Splices & $\mathbf{2}$ \\
\hline Archival Status & Archival Element \\
\hline Overall Condition & Mediocre \\
\hline
\end{tabular}

\begin{tabular}{|l|l|}
\hline Accession Number & $\mathbf{2 0 1 5 . 0 0 0 2 . 0 1 7 8}$ \\
\hline Title & [Untitled- Oct 80] \\
\hline Gauge & Super 8mm \\
\hline Date Code & $\mathbf{1 9 7 9}$ \\
\hline Colour & Colour \\
\hline Film Polarity & Reversal \\
\hline Element & Camera Original \\
\hline Sound & Magnetic Stripe \\
\hline FPS & Unknown \\
\hline Aspect Ratio & $\mathbf{1 : 3 3 : 1}$ \\
\hline Length & $\mathbf{5 0 . 0}$ ft. \\
\hline Film Wind & Unknown \\
\hline $\begin{array}{l}\text { Stock } \\
\text { Manufacturer/Type }\end{array}$ & Eastman Kodak/ Kodachrome \\
\hline Base Type & Triacetate \\
\hline Splices & 0 \\
\hline Archival Status & Archival Element \\
\hline Overall Condition & Excellent \\
\hline
\end{tabular}




\begin{tabular}{|l|l|}
\hline Accession Number & $\mathbf{2 0 1 5 . 0 0 0 2 . 0 1 7 9}$ \\
\hline Title & {$[$ Subway Doors/ Kids of Graffiti] } \\
\hline Gauge & Super 8mm \\
\hline Date Code & Unknown \\
\hline Colour & Colour \\
\hline Film Polarity & Reversal \\
\hline Element & Cut Original \\
\hline Sound & Magnetic Stripe \\
\hline FPS & Unknown \\
\hline Aspect Ratio & $\mathbf{1 : 3 3 : 1}$ \\
\hline Length & $\mathbf{5 0 . 0}$ ft. \\
\hline Film Wind & B Wind \\
\hline $\begin{array}{l}\text { Stock } \\
\text { Manufacturer/Type }\end{array}$ & Eastman Kodak/ Ektachrome \\
\hline Base Type & Triacetate \\
\hline Splices & 0 \\
\hline Archival Status & Archival Element \\
\hline Overall Condition & Mediocre \\
\hline
\end{tabular}

\begin{tabular}{|l|l|}
\hline Accession Number & $\mathbf{2 0 1 5 . 0 0 0 2 . 0 1 8 0}$ \\
\hline Title & {$[$ Petra's Carnival] } \\
\hline Gauge & Super 8mm \\
\hline Date Code & $\mathbf{1 9 7 9}$ \\
\hline Colour & Colour \\
\hline Film Polarity & Reversal \\
\hline Element & Camera Original \\
\hline Sound & Magnetic Stripe \\
\hline FPS & Unknown \\
\hline Aspect Ratio & $\mathbf{1 : 3 3 : 1}$ \\
\hline Length & $\mathbf{5 0 . 0}$ ft. \\
\hline Film Wind & Unknown \\
\hline $\begin{array}{l}\text { Stock } \\
\text { Manufacturer/Type }\end{array}$ & Eastman Kodak/ Ektachrome \\
\hline Base Type & Triacetate \\
\hline Splices & 0 \\
\hline Archival Status & Archival Element \\
\hline Overall Condition & Mediocre \\
\hline
\end{tabular}




\begin{tabular}{|l|l|}
\hline Accession Number & $\mathbf{2 0 1 5 . 0 0 0 2 . 0 1 8 1}$ \\
\hline Title & {$[$ Untitled] } \\
\hline Gauge & Super $\mathbf{m m m}$ \\
\hline Date Code & $\mathbf{1 9 8 0}$ \\
\hline Colour & Colour \\
\hline Film Polarity & Reversal \\
\hline Element & Camera Original \\
\hline Sound & Magnetic Stripe \\
\hline FPS & Unknown \\
\hline Aspect Ratio & $\mathbf{1 : 3 3 : 1}$ \\
\hline Length & $\mathbf{5 0 . 0}$ ft. \\
\hline Film Wind & B Wind \\
\hline $\begin{array}{l}\text { Stock } \\
\text { Manufacturer/Type }\end{array}$ & Eastman Kodak/ Ektachrome \\
\hline Base Type & Triacetate \\
\hline Splices & O \\
\hline Archival Status & Archival Element \\
\hline Overall Condition & Mediocre \\
\hline
\end{tabular}

\begin{tabular}{|l|l|}
\hline Accession Number & $\mathbf{2 0 1 5 . 0 0 0 2 . 0 1 8 2}$ \\
\hline Title & {$[$ Untitled] } \\
\hline Gauge & Super 8mm \\
\hline Date Code & Unknown \\
\hline Colour & Colour \\
\hline Film Polarity & Reversal \\
\hline Element & Camera Original \\
\hline Sound & Magnetic Stripe \\
\hline FPS & Unknown \\
\hline Aspect Ratio & $\mathbf{1 : 3 3 : 1}$ \\
\hline Length & $\mathbf{5 0 . 0}$ ft. \\
\hline Film Wind & B Wind \\
\hline $\begin{array}{l}\text { Stock } \\
\text { Manufacturer/Type }\end{array}$ & Eastman Kodak/ Ektachrome \\
\hline Base Type & Triacetate \\
\hline Splices & O \\
\hline Archival Status & Archival Element \\
\hline Overall Condition & Mediocre \\
\hline
\end{tabular}




\begin{tabular}{|l|l|}
\hline Accession Number & $\mathbf{2 0 1 5 . 0 0 0 2 . 0 1 8 3}$ \\
\hline Title & {$\left[\mathbf{5 1}{ }^{\text {st }}\right.$ Street/ Fishing/ Bowery Wall $]$} \\
\hline Gauge & Super $\mathbf{m m m}$ \\
\hline Date Code & $\mathbf{1 9 8 1}$ \\
\hline Colour & Colour \\
\hline Film Polarity & Reversal \\
\hline Element & Cut Original \\
\hline Sound & Magnetic Stripe \\
\hline FPS & Unknown \\
\hline Aspect Ratio & $\mathbf{1 : 3 3 : 1}$ \\
\hline Length & $\mathbf{5 0 . 0}$ ft. \\
\hline Film Wind & B Wind \\
\hline $\begin{array}{l}\text { Stock } \\
\text { Manufacturer/Type }\end{array}$ & Eastman Kodak/ Kodachrome \\
\hline Base Type & Triacetate \\
\hline Splices & $\mathbf{5}$ \\
\hline Archival Status & Archival Element \\
\hline Overall Condition & Good \\
\hline
\end{tabular}

\begin{tabular}{|l|l|}
\hline Accession Number & $\mathbf{2 0 1 5 . 0 0 0 2 . 0 1 8 4}$ \\
\hline Title & [Airplane- 1980] \\
\hline Gauge & Super 8mm \\
\hline Date Code & $\mathbf{1 9 8 0}$ \\
\hline Colour & Colour \\
\hline Film Polarity & Reversal \\
\hline Element & Camera Original \\
\hline Sound & Magnetic Stripe \\
\hline FPS & Unknown \\
\hline Aspect Ratio & $\mathbf{1 : 3 3 : 1}$ \\
\hline Length & $\mathbf{5 0 . 0}$ ft. \\
\hline Film Wind & B Wind \\
\hline $\begin{array}{l}\text { Stock } \\
\text { Manufacturer/Type }\end{array}$ & Eastman Kodak/ Kodachrome \\
\hline Base Type & Triacetate \\
\hline Splices & O \\
\hline Archival Status & Archival Element \\
\hline Overall Condition & Good \\
\hline
\end{tabular}




\begin{tabular}{|l|l|}
\hline Accession Number & $\mathbf{2 0 1 5 . 0 0 0 2 . 0 1 8 5}$ \\
\hline Title & [Werners Apartment] \\
\hline Gauge & Super 8mm \\
\hline Date Code & $\mathbf{1 9 8 0}$ \\
\hline Colour & Colour \\
\hline Film Polarity & Reversal \\
\hline Element & Camera Original \\
\hline Sound & Magnetic Stripe \\
\hline FPS & Unknown \\
\hline Aspect Ratio & $\mathbf{1 : 3 3 : 1}$ \\
\hline Length & $\mathbf{5 0 . 0}$ ft. \\
\hline Film Wind & B Wind \\
\hline $\begin{array}{l}\text { Stock } \\
\text { Manufacturer/Type }\end{array}$ & Eastman Kodak/ Kodachrome \\
\hline Base Type & Triacetate \\
\hline Splices & O \\
\hline Archival Status & Archival Element \\
\hline Overall Condition & Good \\
\hline
\end{tabular}

\begin{tabular}{|l|l|}
\hline Accession Number & $\mathbf{2 0 1 5 . 0 0 0 2 . 0 1 8 6}$ \\
\hline Title & {$[$ R.L's Party] } \\
\hline Gauge & Super 8mm \\
\hline Date Code & $\mathbf{1 9 8 0}$ \\
\hline Colour & Colour \\
\hline Film Polarity & Reversal \\
\hline Element & Camera Original \\
\hline Sound & Magnetic Stripe \\
\hline FPS & Unknown \\
\hline Aspect Ratio & $\mathbf{1 : 3 3 : 1}$ \\
\hline Length & $\mathbf{5 0 . 0} \mathrm{ft}$. \\
\hline Film Wind & B Wind \\
\hline $\begin{array}{l}\text { Stock } \\
\text { Manufacturer/Type }\end{array}$ & Eastman Kodak/ Ektachrome \\
\hline Base Type & Triacetate \\
\hline Splices & $\mathbf{0}$ \\
\hline Archival Status & Archival Element \\
\hline Overall Condition & Mediocre \\
\hline
\end{tabular}




\begin{tabular}{|l|l|}
\hline Accession Number & $\mathbf{2 0 1 5 . 0 0 0 2 . 0 1 8 7}$ \\
\hline Title & [Untitled] \\
\hline Gauge & Super 8mm \\
\hline Date Code & $\mathbf{1 9 8 1}$ \\
\hline Colour & Colour \\
\hline Film Polarity & Reversal \\
\hline Element & Camera Original \\
\hline Sound & Magnetic Stripe \\
\hline FPS & Unknown \\
\hline Aspect Ratio & $\mathbf{1 : 3 3 : 1}$ \\
\hline Length & $\mathbf{5 0 . 0}$ ft. \\
\hline Film Wind & B Wind \\
\hline $\begin{array}{l}\text { Stock } \\
\text { Manufacturer/Type }\end{array}$ & Eastman Kodak/ Ektachrome \\
\hline Base Type & Triacetate \\
\hline Splices & O \\
\hline Archival Status & Archival Element \\
\hline Overall Condition & Mediocre \\
\hline
\end{tabular}

\begin{tabular}{|l|l|}
\hline Accession Number & $\mathbf{2 0 1 5 . 0 0 0 2 . 0 1 8 8}$ \\
\hline Title & {$[$ Untitled] } \\
\hline Gauge & Super 8mm \\
\hline Date Code & Unknown \\
\hline Colour & Colour \\
\hline Film Polarity & Reversal \\
\hline Element & Camera Original \\
\hline Sound & Magnetic Stripe \\
\hline FPS & Unknown \\
\hline Aspect Ratio & $\mathbf{1 : 3 3 : 1}$ \\
\hline Length & $\mathbf{1 0 . 0} \mathrm{ft}$. \\
\hline Film Wind & B Wind \\
\hline $\begin{array}{l}\text { Stock } \\
\text { Manufacturer/Type }\end{array}$ & Eastman Kodak/ Ektachrome \\
\hline Base Type & Triacetate \\
\hline Splices & 0 \\
\hline Archival Status & Archival Element \\
\hline Overall Condition & Mediocre \\
\hline
\end{tabular}




\begin{tabular}{|l|l|}
\hline Accession Number & 2015.0002 .0189 \\
\hline Title & {$[$ Airplane Film] } \\
\hline Gauge & Super 8mm \\
\hline Date Code & 1980 \\
\hline Colour & Colour \\
\hline Film Polarity & Reversal \\
\hline Element & Cut Original \\
\hline Sound & Magnetic Stripe \\
\hline FPS & Unknown \\
\hline Aspect Ratio & $1: 33: 1$ \\
\hline Length & $10.0 \mathrm{ft}$. \\
\hline Film Wind & B Wind \\
\hline $\begin{array}{l}\text { Stock } \\
\text { Manufacturer/Type }\end{array}$ & Eastman Kodak/ Kodachrome \\
\hline Base Type & Triacetate \\
\hline Splices & 1 \\
\hline Archival Status & Archival Element \\
\hline Overall Condition & Good \\
\hline
\end{tabular}

\begin{tabular}{|l|l|}
\hline Accession Number & $\mathbf{2 0 1 5 . 0 0 0 2 . 0 1 9 0}$ \\
\hline Title & {$[$ Untitled] } \\
\hline Gauge & Super 8mm \\
\hline Date Code & Unknown \\
\hline Colour & Colour \\
\hline Film Polarity & Reversal \\
\hline Element & Camera Original \\
\hline Sound & Magnetic Stripe \\
\hline FPS & Unknown \\
\hline Aspect Ratio & $\mathbf{1 : 3 3 : 1}$ \\
\hline Length & $\mathbf{5 0 . 0}$ ft. \\
\hline Film Wind & B Wind \\
\hline $\begin{array}{l}\text { Stock } \\
\text { Manufacturer/Type }\end{array}$ & Eastman Kodak/ Ektachrome \\
\hline Base Type & Triacetate \\
\hline Splices & 0 \\
\hline Archival Status & Archival Element \\
\hline Overall Condition & Mediocre \\
\hline
\end{tabular}




\begin{tabular}{|l|l|}
\hline Accession Number & $\mathbf{2 0 1 5 . 0 0 0 2 . 0 1 9 1}$ \\
\hline Title & {$[$ November, 1981] } \\
\hline Gauge & Super 8mm \\
\hline Date Code & $\mathbf{1 9 8 0}$ \\
\hline Colour & Colour \\
\hline Film Polarity & Reversal \\
\hline Element & Camera Original \\
\hline Sound & Magnetic Stripe \\
\hline FPS & Unknown \\
\hline Aspect Ratio & $\mathbf{1 : 3 3 : 1}$ \\
\hline Length & $\mathbf{5 0 . 0}$ ft. \\
\hline Film Wind & B Wind \\
\hline $\begin{array}{l}\text { Stock } \\
\text { Manufacturer/Type }\end{array}$ & Eastman Kodak/ Ektachrome \\
\hline Base Type & Triacetate \\
\hline Splices & 0 \\
\hline Archival Status & Archival Element \\
\hline Overall Condition & Good \\
\hline
\end{tabular}

\begin{tabular}{|l|l|}
\hline Accession Number & $\mathbf{2 0 1 5 . 0 0 0 2 . 0 1 9 2}$ \\
\hline Title & {$[$ Untitled] } \\
\hline Gauge & Super 8mm \\
\hline Date Code & Unknown \\
\hline Colour & Colour \\
\hline Film Polarity & Reversal \\
\hline Element & Cut Original \\
\hline Sound & Magnetic Stripe \\
\hline FPS & Unknown \\
\hline Aspect Ratio & $\mathbf{1 : 3 3 : 1}$ \\
\hline Length & $\mathbf{5 0 . 0}$ ft. \\
\hline Film Wind & Unknown \\
\hline $\begin{array}{l}\text { Stock } \\
\text { Manufacturer/Type }\end{array}$ & Eastman Kodak/ Ektachrome \\
\hline Base Type & Triacetate \\
\hline Splices & $\mathbf{2}$ \\
\hline Archival Status & Archival Element \\
\hline Overall Condition & Good \\
\hline
\end{tabular}




\begin{tabular}{|l|l|}
\hline Accession Number & 2015.0002 .0193 \\
\hline Title & {$\left[\right.$ Boy on corner of $49^{\text {th }}$ St. $]$} \\
\hline Gauge & Super 8mm \\
\hline Date Code & Unknown \\
\hline Colour & Colour \\
\hline Film Polarity & Reversal \\
\hline Element & Cut Original \\
\hline Sound & Magnetic Stripe \\
\hline FPS & Unknown \\
\hline Aspect Ratio & $1: 33: 1$ \\
\hline Length & $\mathbf{5 0 . 0} \mathrm{ft}$. \\
\hline Film Wind & B Wind \\
\hline $\begin{array}{l}\text { Stock } \\
\text { Manufacturer/Type }\end{array}$ & Eastman Kodak/ Ektachrome \\
\hline Base Type & Triacetate \\
\hline Splices & 1 \\
\hline Archival Status & Archival Element \\
\hline Overall Condition & Good \\
\hline
\end{tabular}

\begin{tabular}{|l|l|}
\hline Accession Number & $\mathbf{2 0 1 5 . 0 0 0 2 . 0 1 9 4}$ \\
\hline Title & {$[$ Belize- 1982] } \\
\hline Gauge & Super 8mm \\
\hline Date Code & $\mathbf{1 9 8 2}$ \\
\hline Colour & Colour \\
\hline Film Polarity & Reversal \\
\hline Element & Camera Original \\
\hline Sound & Magnetic Stripe \\
\hline FPS & Unknown \\
\hline Aspect Ratio & $\mathbf{1 : 3 3 : 1}$ \\
\hline Length & $\mathbf{1 0 . 0}$ ft. \\
\hline Film Wind & Unknown \\
\hline $\begin{array}{l}\text { Stock } \\
\text { Manufacturer/Type }\end{array}$ & Eastman Kodak/ Ektachrome \\
\hline Base Type & Triacetate \\
\hline Splices & O \\
\hline Archival Status & Archival Element \\
\hline Overall Condition & Mediocre \\
\hline
\end{tabular}




\begin{tabular}{|l|l|}
\hline Accession Number & $\mathbf{2 0 1 5 . 0 0 0 2 . 0 1 9 5}$ \\
\hline Title & [The Clash- NYC From TV] \\
\hline Gauge & Super 8mm \\
\hline Date Code & $\mathbf{1 9 7 9}$ \\
\hline Colour & Colour \\
\hline Film Polarity & Reversal \\
\hline Element & Cut Original \\
\hline Sound & Magnetic Stripe \\
\hline FPS & Unknown \\
\hline Aspect Ratio & $\mathbf{1 : 3 3 : 1}$ \\
\hline Length & $\mathbf{5 0 . 0}$ ft. \\
\hline Film Wind & B Wind \\
\hline $\begin{array}{l}\text { Stock } \\
\text { Manufacturer/Type }\end{array}$ & Eastman Kodak/ Ektachrome \\
\hline Base Type & Triacetate \\
\hline Splices & $\mathbf{2}$ \\
\hline Archival Status & Archival Element \\
\hline Overall Condition & Good \\
\hline
\end{tabular}

\begin{tabular}{|l|l|}
\hline Accession Number & $\mathbf{2 0 1 5 . 0 0 0 2 . 0 1 9 6}$ \\
\hline Title & {$[$ Untitled] } \\
\hline Gauge & Super 8mm \\
\hline Date Code & $\mathbf{1 9 8 0}$ \\
\hline Colour & Colour \\
\hline Film Polarity & Reversal \\
\hline Element & Camera Original \\
\hline Sound & Magnetic Stripe \\
\hline FPS & Unknown \\
\hline Aspect Ratio & $\mathbf{1 : 3 3 : 1}$ \\
\hline Length & $\mathbf{1 0 . 0}$ ft. \\
\hline Film Wind & B Wind \\
\hline $\begin{array}{l}\text { Stock } \\
\text { Manufacturer/Type }\end{array}$ & Eastman Kodak/ Ektachrome \\
\hline Base Type & Triacetate \\
\hline Splices & 0 \\
\hline Archival Status & Archival Element \\
\hline Overall Condition & Good \\
\hline
\end{tabular}




\begin{tabular}{|l|l|}
\hline Accession Number & $\mathbf{2 0 1 5 . 0 0 0 2 . 0 1 9 7}$ \\
\hline Title & {$[$ AB Stand- Dusseldorf] } \\
\hline Gauge & Super 8mm \\
\hline Date Code & $\mathbf{1 9 8 0}$ \\
\hline Colour & Colour \\
\hline Film Polarity & Reversal \\
\hline Element & Camera Original \\
\hline Sound & Magnetic Stripe \\
\hline FPS & Unknown \\
\hline Aspect Ratio & $\mathbf{1 : 3 3 : 1}$ \\
\hline Length & $\mathbf{5 0 . 0}$ ft. \\
\hline Film Wind & B Wind \\
\hline $\begin{array}{l}\text { Stock } \\
\text { Manufacturer/Type }\end{array}$ & Eastman Kodak/ Kodachrome \\
\hline Base Type & Triacetate \\
\hline Splices & O \\
\hline Archival Status & Archival Element \\
\hline Overall Condition & Good \\
\hline
\end{tabular}

\begin{tabular}{|l|l|}
\hline Accession Number & $\mathbf{2 0 1 5 . 0 0 0 2 . 0 1 9 8}$ \\
\hline Title & {$[$ Untitled] } \\
\hline Gauge & Super 8mm \\
\hline Date Code & Unknown \\
\hline Colour & Colour \\
\hline Film Polarity & Reversal \\
\hline Element & Camera Original \\
\hline Sound & Magnetic Stripe \\
\hline FPS & Unknown \\
\hline Aspect Ratio & $\mathbf{1 : 3 3 : 1}$ \\
\hline Length & $\mathbf{5 0 . 0}$ ft. \\
\hline Film Wind & B Wind \\
\hline $\begin{array}{l}\text { Stock } \\
\text { Manufacturer/Type }\end{array}$ & Eastman Kodak/ Ektachrome \\
\hline Base Type & Triacetate \\
\hline Splices & 0 \\
\hline Archival Status & Archival Element \\
\hline Overall Condition & Medicore \\
\hline
\end{tabular}




\begin{tabular}{|l|l|}
\hline Accession Number & $\mathbf{2 0 1 5 . 0 0 0 2 . 0 1 9 9}$ \\
\hline Title & {$[$ Ab Slides] } \\
\hline Gauge & Super 8mm \\
\hline Date Code & $\mathbf{1 9 8 3}$ \\
\hline Colour & Colour \\
\hline Film Polarity & Reversal \\
\hline Element & Camera Original \\
\hline Sound & Magnetic Stripe \\
\hline FPS & Unknown \\
\hline Aspect Ratio & $\mathbf{1 : 3 3 : 1}$ \\
\hline Length & $\mathbf{5 0 . 0}$ ft. \\
\hline Film Wind & B Wind \\
\hline $\begin{array}{l}\text { Stock } \\
\text { Manufacturer/Type }\end{array}$ & Eastman Kodak/ Ektachrome \\
\hline Base Type & Triacetate \\
\hline Splices & O \\
\hline Archival Status & Archival Element \\
\hline Overall Condition & Good \\
\hline
\end{tabular}

\begin{tabular}{|l|l|}
\hline Accession Number & $\mathbf{2 0 1 5 . 0 0 0 2 . 0 2 0 0}$ \\
\hline Title & {$[$ Untitled] } \\
\hline Gauge & Super $\mathbf{m m m}$ \\
\hline Date Code & $\mathbf{1 9 8 0}$ \\
\hline Colour & Colour \\
\hline Film Polarity & Reversal \\
\hline Element & Camera Original \\
\hline Sound & Magnetic Stripe \\
\hline FPS & Unknown \\
\hline Aspect Ratio & $\mathbf{1 : 3 3 : 1}$ \\
\hline Length & $\mathbf{2 5 . 0}$ ft. \\
\hline Film Wind & Unknown \\
\hline $\begin{array}{l}\text { Stock } \\
\text { Manufacturer/Type }\end{array}$ & Eastman Kodak/ Ektachrome \\
\hline Base Type & Triacetate \\
\hline Splices & O \\
\hline Archival Status & Archival Element \\
\hline Overall Condition & Mediocre \\
\hline
\end{tabular}




\begin{tabular}{|l|l|}
\hline Accession Number & $\mathbf{2 0 1 5 . 0 0 0 2 . 0 2 0 1}$ \\
\hline Title & {$[$ Bruce Teed] } \\
\hline Gauge & Super $8 \mathrm{~mm}$ \\
\hline Date Code & $\mathbf{1 9 8 4}$ \\
\hline Colour & Colour \\
\hline Film Polarity & Reversal \\
\hline Element & Cut Original \\
\hline Sound & Magnetic Stripe \\
\hline FPS & Unknown \\
\hline Aspect Ratio & $\mathbf{1 : 3 3 : 1}$ \\
\hline Length & $\mathbf{5 0 . 0}$ ft. \\
\hline Film Wind & B Wind \\
\hline $\begin{array}{l}\text { Stock } \\
\text { Manufacturer/Type }\end{array}$ & Eastman Kodak/ Kodachrome \\
\hline Base Type & Triacetate \\
\hline Splices & $\mathbf{1}$ \\
\hline Archival Status & Archival Element \\
\hline Overall Condition & Good \\
\hline
\end{tabular}

\begin{tabular}{|l|l|}
\hline Accession Number & 2015.0002 .0202 \\
\hline Title & {$[$ S.N.A.F.U/ Cooper Hewitt T.V] } \\
\hline Gauge & Super 8mm \\
\hline Date Code & Unknown \\
\hline Colour & Colour \\
\hline Film Polarity & Reversal \\
\hline Element & Cut Original \\
\hline Sound & Magnetic Stripe \\
\hline FPS & Unknown \\
\hline Aspect Ratio & $1: 33: 1$ \\
\hline Length & $15.0 \mathrm{ft}$. \\
\hline Film Wind & B Wind \\
\hline $\begin{array}{l}\text { Stock } \\
\text { Manufacturer/Type }\end{array}$ & Eastman Kodak/ Ektachrome \\
\hline Base Type & Triacetate \\
\hline Splices & 1 \\
\hline Archival Status & Archival Element \\
\hline Overall Condition & Good \\
\hline
\end{tabular}




\begin{tabular}{|l|l|}
\hline Accession Number & $\mathbf{2 0 1 5 . 0 0 0 2 . 0 2 0 3}$ \\
\hline Title & {$[$ Bruce Teed] } \\
\hline Gauge & Super $\mathbf{m m m}$ \\
\hline Date Code & $\mathbf{1 9 8 4}$ \\
\hline Colour & Colour \\
\hline Film Polarity & Reversal \\
\hline Element & Cut Original \\
\hline Sound & Magnetic Stripe \\
\hline FPS & Unknown \\
\hline Aspect Ratio & $\mathbf{1 : 3 3 : 1}$ \\
\hline Length & $\mathbf{5 0 . 0}$ ft. \\
\hline Film Wind & B Wind \\
\hline $\begin{array}{l}\text { Stock } \\
\text { Manufacturer/Type }\end{array}$ & Eastman Kodak/ Kodachrome \\
\hline Base Type & Triacetate \\
\hline Splices & $\mathbf{1}$ \\
\hline Archival Status & Archival Element \\
\hline Overall Condition & Good \\
\hline
\end{tabular}

\begin{tabular}{|l|l|}
\hline Accession Number & $\mathbf{2 0 1 5 . 0 0 0 2 . 0 2 0 4}$ \\
\hline Title & {$[$ Untitled] } \\
\hline Gauge & Super 8mm \\
\hline Date Code & $\mathbf{1 9 8 0}$ \\
\hline Colour & Colour \\
\hline Film Polarity & Reversal \\
\hline Element & Camera Original \\
\hline Sound & Magnetic Stripe \\
\hline FPS & Unknown \\
\hline Aspect Ratio & $\mathbf{1 : 3 3 : 1}$ \\
\hline Length & $\mathbf{5 0 . 0} \mathrm{ft}$. \\
\hline Film Wind & B Wind \\
\hline $\begin{array}{l}\text { Stock } \\
\text { Manufacturer/Type }\end{array}$ & Eastman Kodak/ Ektachrome \\
\hline Base Type & Triacetate \\
\hline Splices & $\mathbf{0}$ \\
\hline Archival Status & Archival Element \\
\hline Overall Condition & Mediocre \\
\hline
\end{tabular}




\begin{tabular}{|l|l|}
\hline Accession Number & $\mathbf{2 0 1 5 . 0 0 0 2 . 0 2 0 5}$ \\
\hline Title & {$[$ How She/Painting/Window] } \\
\hline Gauge & Super 8mm \\
\hline Date Code & Unknown \\
\hline Colour & Colour \\
\hline Film Polarity & Reversal \\
\hline Element & Cut Original \\
\hline Sound & Magnetic Stripe \\
\hline FPS & Unknown \\
\hline Aspect Ratio & $\mathbf{1 : 3 3 : 1}$ \\
\hline Length & $\mathbf{5 0 . 0}$ ft. \\
\hline Film Wind & B Wind \\
\hline $\begin{array}{l}\text { Stock } \\
\text { Manufacturer/Type }\end{array}$ & Eastman Kodak/ Ektachrome \\
\hline Base Type & Triacetate \\
\hline Splices & $\mathbf{2}$ \\
\hline Archival Status & Archival Element \\
\hline Overall Condition & Mediocre \\
\hline
\end{tabular}

\begin{tabular}{|l|l|}
\hline Accession Number & $\mathbf{2 0 1 5 . 0 0 0 2 . 0 2 0 6}$ \\
\hline Title & {$[$ Untitled] } \\
\hline Gauge & Super 8mm \\
\hline Date Code & Unknown \\
\hline Colour & Colour \\
\hline Film Polarity & Reversal \\
\hline Element & Camera Original \\
\hline Sound & Magnetic Stripe \\
\hline FPS & Unknown \\
\hline Aspect Ratio & $\mathbf{1 : 3 3 : 1}$ \\
\hline Length & $\mathbf{5 0 . 0} \mathrm{ft}$. \\
\hline Film Wind & Unknown \\
\hline $\begin{array}{l}\text { Stock } \\
\text { Manufacturer/Type }\end{array}$ & Eastman Kodak/ Ektachrome \\
\hline Base Type & Triacetate \\
\hline Splices & 0 \\
\hline Archival Status & Archival Element \\
\hline Overall Condition & Mediocre \\
\hline
\end{tabular}




\begin{tabular}{|l|l|}
\hline Accession Number & $\mathbf{2 0 1 5 . 0 0 0 2 . 0 2 0 7}$ \\
\hline Title & [Untitled] \\
\hline Gauge & Super 8mm \\
\hline Date Code & Unknown \\
\hline Colour & Colour \\
\hline Film Polarity & Reversal \\
\hline Element & Cut Original \\
\hline Sound & Magnetic Stripe \\
\hline FPS & Unknown \\
\hline Aspect Ratio & $\mathbf{1 : 3 3 : 1}$ \\
\hline Length & $\mathbf{5 0 . 0}$ ft. \\
\hline Film Wind & B Wind \\
\hline $\begin{array}{l}\text { Stock } \\
\text { Manufacturer/Type }\end{array}$ & Eastman Kodak/ Ektachrome \\
\hline Base Type & Triacetate \\
\hline Splices & $\mathbf{3}$ \\
\hline Archival Status & Archival Element \\
\hline Overall Condition & Mediocre \\
\hline
\end{tabular}

\begin{tabular}{|c|c|}
\hline Accession Number & 2015.0002 .0208 \\
\hline Title & [Girl on Street Meditating] \\
\hline Gauge & Super $8 \mathrm{~mm}$ \\
\hline Date Code & Unknown \\
\hline Colour & Colour \\
\hline Film Polarity & Reversal \\
\hline Element & Camera Original \\
\hline Sound & Magnetic Stripe \\
\hline FPS & Unknown \\
\hline Aspect Ratio & 1:33:1 \\
\hline Length & $25.0 \mathrm{ft}$. \\
\hline Film Wind & B Wind \\
\hline $\begin{array}{l}\text { Stock } \\
\text { Manufacturer/Type }\end{array}$ & Eastman Kodak/ Ektachrome \\
\hline Base Type & Triacetate \\
\hline Splices & $\mathbf{0}$ \\
\hline Archival Status & Archival Element \\
\hline Overall Condition & Mediocre \\
\hline
\end{tabular}




\begin{tabular}{|l|l|}
\hline Accession Number & $\mathbf{2 0 1 5 . 0 0 0 2 . 0 2 0 9}$ \\
\hline Title & {$[$ Untitled] } \\
\hline Gauge & Super 8mm \\
\hline Date Code & Unknown \\
\hline Colour & Colour \\
\hline Film Polarity & Reversal \\
\hline Element & Camera Original \\
\hline Sound & Magnetic Stripe \\
\hline FPS & Unknown \\
\hline Aspect Ratio & $\mathbf{1 : 3 3 : 1}$ \\
\hline Length & $\mathbf{2 5 . 0}$ ft. \\
\hline Film Wind & Unknown \\
\hline $\begin{array}{l}\text { Stock } \\
\text { Manufacturer/Type }\end{array}$ & Eastman Kodak/ Ektachrome \\
\hline Base Type & Triacetate \\
\hline Splices & O \\
\hline Archival Status & Archival Element \\
\hline Overall Condition & Mediocre \\
\hline
\end{tabular}

\begin{tabular}{|l|l|}
\hline Accession Number & $\mathbf{2 0 1 5 . 0 0 0 2 . 0 2 1 0}$ \\
\hline Title & {$[$ Untitled] } \\
\hline Gauge & Super 8mm \\
\hline Date Code & 1980 \\
\hline Colour & Colour \\
\hline Film Polarity & Reversal \\
\hline Element & Cut Original \\
\hline Sound & Magnetic Stripe \\
\hline FPS & Unknown \\
\hline Aspect Ratio & $\mathbf{1 : 3 3 : 1}$ \\
\hline Length & $\mathbf{2 5 . 0} \mathrm{ft}$. \\
\hline Film Wind & B Wind \\
\hline $\begin{array}{l}\text { Stock } \\
\text { Manufacturer/Type }\end{array}$ & Eastman Kodak/ Ektachrome \\
\hline Base Type & Triacetate \\
\hline Splices & 1 \\
\hline Archival Status & Archival Element \\
\hline Overall Condition & Good \\
\hline
\end{tabular}




\begin{tabular}{|l|l|}
\hline Accession Number & $\mathbf{2 0 1 5 . 0 0 0 2 . 0 2 1 1}$ \\
\hline Title & {$[$ The Performance] } \\
\hline Gauge & Super 8mm \\
\hline Date Code & $\mathbf{1 9 8 0}$ \\
\hline Colour & Colour \\
\hline Film Polarity & Reversal \\
\hline Element & Camera Original \\
\hline Sound & Magnetic Stripe \\
\hline FPS & Unknown \\
\hline Aspect Ratio & $\mathbf{1 : 3 3 : 1}$ \\
\hline Length & $\mathbf{5 0 . 0}$ ft. \\
\hline Film Wind & B Wind \\
\hline $\begin{array}{l}\text { Stock } \\
\text { Manufacturer/Type }\end{array}$ & Eastman Kodak/ Ektachrome \\
\hline Base Type & Triacetate \\
\hline Splices & O \\
\hline Archival Status & Archival Element \\
\hline Overall Condition & Mediocre \\
\hline
\end{tabular}

\begin{tabular}{|l|l|}
\hline Accession Number & 2015.0002 .0212 \\
\hline Title & {$[$ Plastic cake] } \\
\hline Gauge & Super 8mm \\
\hline Date Code & 1980 \\
\hline Colour & Colour \\
\hline Film Polarity & Reversal \\
\hline Element & Cut Original \\
\hline Sound & Magnetic Stripe \\
\hline FPS & Unknown \\
\hline Aspect Ratio & $1: 33: 1$ \\
\hline Length & $\mathbf{2 0 . 0} \mathrm{ft}$. \\
\hline Film Wind & B Wind \\
\hline $\begin{array}{l}\text { Stock } \\
\text { Manufacturer/Type }\end{array}$ & Eastman Kodak/ Ektachrome \\
\hline Base Type & Triacetate \\
\hline Splices & 1 \\
\hline Archival Status & Archival Element \\
\hline Overall Condition & Mediocre \\
\hline
\end{tabular}




\begin{tabular}{|l|l|}
\hline Accession Number & $\mathbf{2 0 1 5 . 0 0 0 2 . 0 2 1 3}$ \\
\hline Title & {$[$ Untitled] } \\
\hline Gauge & Super 8mm \\
\hline Date Code & $\mathbf{1 9 8 0}$ \\
\hline Colour & Colour \\
\hline Film Polarity & Reversal \\
\hline Element & Camera Original \\
\hline Sound & Magnetic Stripe \\
\hline FPS & Unknown \\
\hline Aspect Ratio & $\mathbf{1 : 3 3 : 1}$ \\
\hline Length & $\mathbf{5 0 . 0}$ ft. \\
\hline Film Wind & Unknown \\
\hline $\begin{array}{l}\text { Stock } \\
\text { Manufacturer/Type }\end{array}$ & Eastman Kodak/ Ektachrome \\
\hline Base Type & Triacetate \\
\hline Splices & O \\
\hline Archival Status & Archival Element \\
\hline Overall Condition & Mediocre \\
\hline
\end{tabular}

\begin{tabular}{|l|l|}
\hline Accession Number & $\mathbf{2 0 1 5 . 0 0 0 2 . 0 2 1 4}$ \\
\hline Title & {$[$ Untitled- Oct 84] } \\
\hline Gauge & Super 8mm \\
\hline Date Code & 1984 \\
\hline Colour & Colour \\
\hline Film Polarity & Reversal \\
\hline Element & Cut Original \\
\hline Sound & Magnetic Stripe \\
\hline FPS & Unknown \\
\hline Aspect Ratio & $\mathbf{1 : 3 3 : 1}$ \\
\hline Length & $\mathbf{2 5 . 0} \mathrm{ft}$. \\
\hline Film Wind & B Wind \\
\hline $\begin{array}{l}\text { Stock } \\
\text { Manufacturer/Type }\end{array}$ & Eastman Kodak/ Kodachrome \\
\hline Base Type & Triacetate \\
\hline Splices & $\mathbf{2}$ \\
\hline Archival Status & Archival Element \\
\hline Overall Condition & Good \\
\hline
\end{tabular}




\begin{tabular}{|l|l|}
\hline Accession Number & $\mathbf{2 0 1 5 . 0 0 0 2 . 0 2 1 5}$ \\
\hline Title & {$[$ Untitled] } \\
\hline Gauge & Super 8mm \\
\hline Date Code & $\mathbf{1 9 7 9}$ \\
\hline Colour & Colour \\
\hline Film Polarity & Reversal \\
\hline Element & Camera Original \\
\hline Sound & Magnetic Stripe \\
\hline FPS & Unknown \\
\hline Aspect Ratio & $\mathbf{1 : 3 3 : 1}$ \\
\hline Length & $\mathbf{1 0 . 0}$ ft. \\
\hline Film Wind & Unknown \\
\hline $\begin{array}{l}\text { Stock } \\
\text { Manufacturer/Type }\end{array}$ & Eastman Kodak/ Kodachrome \\
\hline Base Type & Triacetate \\
\hline Splices & 0 \\
\hline Archival Status & Archival Element \\
\hline Overall Condition & Good \\
\hline
\end{tabular}

\begin{tabular}{|l|l|}
\hline Accession Number & $\mathbf{2 0 1 5 . 0 0 0 2 . 0 2 1 6}$ \\
\hline Title & {$[$ Untitled] } \\
\hline Gauge & Super 8mm \\
\hline Date Code & Unknown \\
\hline Colour & Colour \\
\hline Film Polarity & Reversal \\
\hline Element & Cut Original \\
\hline Sound & Magnetic Stripe \\
\hline FPS & Unknown \\
\hline Aspect Ratio & $\mathbf{1 : 3 3 : 1}$ \\
\hline Length & $\mathbf{1 5 . 0}$ ft. \\
\hline Film Wind & B Wind \\
\hline $\begin{array}{l}\text { Stock } \\
\text { Manufacturer/Type }\end{array}$ & Eastman Kodak/ Ektachrome \\
\hline Base Type & Triacetate \\
\hline Splices & $\mathbf{2}$ \\
\hline Archival Status & Archival Element \\
\hline Overall Condition & Good \\
\hline
\end{tabular}




\begin{tabular}{|l|l|}
\hline Accession Number & $\mathbf{2 0 1 5 . 0 0 0 2 . 0 2 1 7}$ \\
\hline Title & {$[$ A's Part II] } \\
\hline Gauge & Super $8 \mathrm{~mm}$ \\
\hline Date Code & $\mathbf{1 9 8 0}$ \\
\hline Colour & Colour \\
\hline Film Polarity & Reversal \\
\hline Element & Cut Original \\
\hline Sound & Magnetic Stripe \\
\hline FPS & Unknown \\
\hline Aspect Ratio & $\mathbf{1 : 3 3 : 1}$ \\
\hline Length & $\mathbf{2 5 . 0}$ ft. \\
\hline Film Wind & B Wind \\
\hline $\begin{array}{l}\text { Stock } \\
\text { Manufacturer/Type }\end{array}$ & Eastman Kodak/ Ektachrome \\
\hline Base Type & Triacetate \\
\hline Splices & $\mathbf{1}$ \\
\hline Archival Status & Archival Element \\
\hline Overall Condition & Mediocre \\
\hline
\end{tabular}

\begin{tabular}{|l|l|}
\hline Accession Number & $\mathbf{2 0 1 5 . 0 0 0 2 . 0 2 1 8}$ \\
\hline Title & {$[$ Untitled] } \\
\hline Gauge & Super 8mm \\
\hline Date Code & $\mathbf{1 9 7 9}$ \\
\hline Colour & Colour \\
\hline Film Polarity & Reversal \\
\hline Element & Camera Original \\
\hline Sound & Mag Stripe \\
\hline FPS & Unknown \\
\hline Aspect Ratio & $\mathbf{1 : 3 3 : 1}$ \\
\hline Length & $\mathbf{5 0 . 0}$ ft. \\
\hline Film Wind & B Wind \\
\hline $\begin{array}{l}\text { Stock } \\
\text { Manufacturer/Type }\end{array}$ & Eastman Kodak/ Ektachrome \\
\hline Base Type & Triacetate \\
\hline Splices & 0 \\
\hline Archival Status & Archival Element \\
\hline Overall Condition & Mediocre \\
\hline
\end{tabular}




\begin{tabular}{|l|l|}
\hline Accession Number & $\mathbf{2 0 1 5 . 0 0 0 2 . 0 2 1 9}$ \\
\hline Title & {$[$ Untitled] } \\
\hline Gauge & Super $\mathbf{m m m}$ \\
\hline Date Code & $\mathbf{1 9 8 0}$ \\
\hline Colour & Colour \\
\hline Film Polarity & Reversal \\
\hline Element & Camera Original \\
\hline Sound & Magnetic Stripe \\
\hline FPS & Unknown \\
\hline Aspect Ratio & $\mathbf{1 : 3 3 : 1}$ \\
\hline Length & $\mathbf{5 0 . 0}$ ft. \\
\hline Film Wind & B Wind \\
\hline $\begin{array}{l}\text { Stock } \\
\text { Manufacturer/Type }\end{array}$ & Eastman Kodak/ Ektachrome \\
\hline Base Type & Triacetate \\
\hline Splices & $\mathbf{1}$ \\
\hline Archival Status & Archival Element \\
\hline Overall Condition & Good \\
\hline
\end{tabular}

\begin{tabular}{|l|l|}
\hline Accession Number & $\mathbf{2 0 1 5 . 0 0 0 2 . 0 2 2 0}$ \\
\hline Title & {$[$ Dusseldorf Carnival] } \\
\hline Gauge & Super 8mm \\
\hline Date Code & $\mathbf{1 9 8 0}$ \\
\hline Colour & Colour \\
\hline Film Polarity & Reversal \\
\hline Element & Camera Original \\
\hline Sound & Magnetic Stripe \\
\hline FPS & Unknown \\
\hline Aspect Ratio & $\mathbf{1 : 3 3 : 1}$ \\
\hline Length & $\mathbf{5 0 . 0}$ ft. \\
\hline Film Wind & B Wind \\
\hline $\begin{array}{l}\text { Stock } \\
\text { Manufacturer/Type }\end{array}$ & Eastman Kodak/ Ektachrome \\
\hline Base Type & Triacetate \\
\hline Splices & 0 \\
\hline Archival Status & Archival Element \\
\hline Overall Condition & Mediocre \\
\hline
\end{tabular}




\begin{tabular}{|l|l|}
\hline Accession Number & $\mathbf{2 0 1 5 . 0 0 0 2 . 0 2 2 1}$ \\
\hline Title & David Bowie From TV in NY \\
\hline Gauge & Super 8mm \\
\hline Date Code & Unknown \\
\hline Colour & Colour \\
\hline Film Polarity & Reversal \\
\hline Element & Camera Original \\
\hline Sound & Magnetic Stripe \\
\hline FPS & Unknown \\
\hline Aspect Ratio & $\mathbf{1 : 3 3 : 1}$ \\
\hline Length & $\mathbf{4 0 . 0}$ ft. \\
\hline Film Wind & B Wind \\
\hline $\begin{array}{l}\text { Stock } \\
\text { Manufacturer/Type }\end{array}$ & Eastman Kodak/ Ektachrome \\
\hline Base Type & Triacetate \\
\hline Splices & $\mathbf{1}$ \\
\hline Archival Status & Archival Element \\
\hline Overall Condition & Good \\
\hline
\end{tabular}

\begin{tabular}{|l|l|}
\hline Accession Number & $\mathbf{2 0 1 5 . 0 0 0 2 . 0 2 2 2}$ \\
\hline Title & [World Trade Center] \\
\hline Gauge & Super 8mm \\
\hline Date Code & $\mathbf{1 9 8 1}$ \\
\hline Colour & Colour \\
\hline Film Polarity & Reversal \\
\hline Element & Cut Original \\
\hline Sound & Magnetic Stripe \\
\hline FPS & Unknown \\
\hline Aspect Ratio & $\mathbf{1 : 3 3 : 1}$ \\
\hline Length & $\mathbf{4 0 . 0}$ ft. \\
\hline Film Wind & B Wind \\
\hline $\begin{array}{l}\text { Stock } \\
\text { Manufacturer/Type }\end{array}$ & Eastman Kodak/ Ektachrome \\
\hline Base Type & Triacetate \\
\hline Splices & 1 \\
\hline Archival Status & Archival Element \\
\hline Overall Condition & Mediocre \\
\hline
\end{tabular}




\begin{tabular}{|l|l|}
\hline Accession Number & $\mathbf{2 0 1 5 . 0 0 0 2 . 0 2 2 3}$ \\
\hline Title & {$[$ Untiled- 1982] } \\
\hline Gauge & Super $\mathbf{8 m m}$ \\
\hline Date Code & $\mathbf{1 9 8 2}$ \\
\hline Colour & Colour \\
\hline Film Polarity & Reversal \\
\hline Element & Cut Original \\
\hline Sound & Magnetic Stripe \\
\hline FPS & Unknown \\
\hline Aspect Ratio & $\mathbf{1 : 3 3 : 1}$ \\
\hline Length & $\mathbf{2 5 . 0}$ ft. \\
\hline Film Wind & B Wind \\
\hline $\begin{array}{l}\text { Stock } \\
\text { Manufacturer/Type }\end{array}$ & Eastman Kodak/ Ektachrome + 1 unidentifiable stock \\
\hline Base Type & Triacetate \\
\hline Splices & $\mathbf{2}$ \\
\hline Archival Status & Archival Element \\
\hline Overall Condition & Good \\
\hline
\end{tabular}

\begin{tabular}{|l|l|}
\hline Accession Number & $\mathbf{2 0 1 5 . 0 0 0 2 . 0 2 2 4}$ \\
\hline Title & {$[$ B/W Eye] } \\
\hline Gauge & Super $8 \mathrm{~mm}$ \\
\hline Date Code & $\mathbf{1 9 7 9}$ \\
\hline Colour & Colour \\
\hline Film Polarity & Reversal \\
\hline Element & Camera Original \\
\hline Sound & Silent \\
\hline FPS & Unknown \\
\hline Aspect Ratio & $\mathbf{1 : 3 3 : 1}$ \\
\hline Length & $\mathbf{2 5 . 0}$ ft. \\
\hline Film Wind & Unknown \\
\hline $\begin{array}{l}\text { Stock } \\
\text { Manufacturer/Type }\end{array}$ & Eastman Kodak/ Ektachrome \\
\hline Base Type & Triacetate \\
\hline Splices & O \\
\hline Archival Status & Archival Element \\
\hline Overall Condition & Good \\
\hline
\end{tabular}




\begin{tabular}{|l|l|}
\hline Accession Number & $\mathbf{2 0 1 5 . 0 0 0 2 . 0 2 2 5}$ \\
\hline Title & {$[$ A's Museum] } \\
\hline Gauge & Super 8mm \\
\hline Date Code & $\mathbf{1 9 8 0}$ \\
\hline Colour & Colour \\
\hline Film Polarity & Reversal \\
\hline Element & Camera Original \\
\hline Sound & Magnetic Stripe \\
\hline FPS & Unknown \\
\hline Aspect Ratio & $\mathbf{1 : 3 3 : 1}$ \\
\hline Length & $\mathbf{5 0 . 0}$ ft. \\
\hline Film Wind & B Wind \\
\hline $\begin{array}{l}\text { Stock } \\
\text { Manufacturer/Type }\end{array}$ & Eastman Kodak/ Ektachrome \\
\hline Base Type & Triacetate \\
\hline Splices & $\mathbf{1}$ \\
\hline Archival Status & Archival Element \\
\hline Overall Condition & Mediocre \\
\hline
\end{tabular}

\begin{tabular}{|l|l|}
\hline Accession Number & $\mathbf{2 0 1 5 . 0 0 0 2 . 0 2 2 6}$ \\
\hline Title & {$[$ Airplane Film Part I] } \\
\hline Gauge & Super 8mm \\
\hline Date Code & $\mathbf{1 9 8 0}$ \\
\hline Colour & Colour \\
\hline Film Polarity & Reversal \\
\hline Element & Camera Original \\
\hline Sound & Magnetic Stripe \\
\hline FPS & Unknown \\
\hline Aspect Ratio & $\mathbf{1 : 3 3 : 1}$ \\
\hline Length & $\mathbf{5 0 . 0}$ ft. \\
\hline Film Wind & Unknown \\
\hline $\begin{array}{l}\text { Stock } \\
\text { Manufacturer/Type }\end{array}$ & Eastman Kodak/ Ektachrome \\
\hline Base Type & Triacetate \\
\hline Splices & 1 \\
\hline Archival Status & Archival Element \\
\hline Overall Condition & Mediocre \\
\hline
\end{tabular}




\begin{tabular}{|l|l|}
\hline Accession Number & $\mathbf{2 0 1 5 . 0 0 0 2 . 0 2 2 7}$ \\
\hline Title & {$[$ Airplane Film Part II] } \\
\hline Gauge & Super 8mm \\
\hline Date Code & $\mathbf{1 9 8 0}$ \\
\hline Colour & Colour \\
\hline Film Polarity & Reversal \\
\hline Element & Cut Original \\
\hline Sound & Magnetic Stripe \\
\hline FPS & Unknown \\
\hline Aspect Ratio & $\mathbf{1 : 3 3 : 1}$ \\
\hline Length & $\mathbf{1 5 . 0}$ ft. \\
\hline Film Wind & Unknown \\
\hline $\begin{array}{l}\text { Stock } \\
\text { Manufacturer/Type }\end{array}$ & Eastman Kodak/ Ektachrome \\
\hline Base Type & Triacetate \\
\hline Splices & $\mathbf{3}$ \\
\hline Archival Status & Archival Element \\
\hline Overall Condition & Mediocre \\
\hline
\end{tabular}

\begin{tabular}{|l|l|}
\hline Accession Number & $\mathbf{2 0 1 5 . 0 0 0 2 . 0 2 2 8}$ \\
\hline Title & {$[$ Untitled] } \\
\hline Gauge & Super 8mm \\
\hline Date Code & Unknown \\
\hline Colour & Colour \\
\hline Film Polarity & Reversal \\
\hline Element & Cut Original \\
\hline Sound & Magnetic Stripe \\
\hline FPS & Unknown \\
\hline Aspect Ratio & $\mathbf{1 : 3 3 : 1}$ \\
\hline Length & $\mathbf{1 5 . 0}$ ft. \\
\hline Film Wind & B Wind \\
\hline $\begin{array}{l}\text { Stock } \\
\text { Manufacturer/Type }\end{array}$ & Eastman Kodak/ Ektachrome \\
\hline Base Type & Triacetate \\
\hline Splices & $\mathbf{2}$ \\
\hline Archival Status & Archival Element \\
\hline Overall Condition & Mediocre \\
\hline
\end{tabular}




\begin{tabular}{|l|l|}
\hline Accession Number & $\mathbf{2 0 1 5 . 0 0 0 2 . 0 2 2 9}$ \\
\hline Title & [Do Da Performance \#2] \\
\hline Gauge & Super 8mm \\
\hline Date Code & $\mathbf{1 9 8 0}$ \\
\hline Colour & Colour \\
\hline Film Polarity & Reversal \\
\hline Element & Cut Original \\
\hline Sound & Magnetic Stripe \\
\hline FPS & Unknown \\
\hline Aspect Ratio & $\mathbf{1 : 3 3 : 1}$ \\
\hline Length & $\mathbf{5 0 . 0}$ ft. \\
\hline Film Wind & Unknown \\
\hline $\begin{array}{l}\text { Stock } \\
\text { Manufacturer/Type }\end{array}$ & Eastman Kodak/ Kodachrome \\
\hline Base Type & Triacetate \\
\hline Splices & $\mathbf{2}$ \\
\hline Archival Status & Archival Element \\
\hline Overall Condition & Mediocre \\
\hline
\end{tabular}

\begin{tabular}{|l|l|}
\hline Accession Number & $\mathbf{2 0 1 5 . 0 0 0 2 . 0 2 3 0}$ \\
\hline Title & {$[$ Laser TV] } \\
\hline Gauge & Super $8 \mathrm{~mm}$ \\
\hline Date Code & $\mathbf{1 9 8 0}$ \\
\hline Colour & Colour \\
\hline Film Polarity & Reversal \\
\hline Element & Cut Original \\
\hline Sound & Magnetic Stripe \\
\hline FPS & Unknown \\
\hline Aspect Ratio & $\mathbf{1 : 3 3 : 1}$ \\
\hline Length & $\mathbf{1 5 . 0}$ ft. \\
\hline Film Wind & B Wind \\
\hline $\begin{array}{l}\text { Stock } \\
\text { Manufacturer/Type }\end{array}$ & Eastman Kodak/ Ektachrome \\
\hline Base Type & Triacetate \\
\hline Splices & $\mathbf{5}$ \\
\hline Archival Status & Archival Element \\
\hline Overall Condition & Mediocre \\
\hline
\end{tabular}




\begin{tabular}{|l|l|}
\hline Accession Number & $\mathbf{2 0 1 5 . 0 0 0 2 . 0 2 3 1}$ \\
\hline Title & [Sunday on Cycle-1980] \\
\hline Gauge & Super 8mm \\
\hline Date Code & $\mathbf{1 9 8 0}$ \\
\hline Colour & Colour \\
\hline Film Polarity & Reversal \\
\hline Element & Camera Original \\
\hline Sound & Magnetic Stripe \\
\hline FPS & Unknown \\
\hline Aspect Ratio & $\mathbf{1 : 3 3 : 1}$ \\
\hline Length & $\mathbf{1 5 . 0}$ ft. \\
\hline Film Wind & B Wind \\
\hline $\begin{array}{l}\text { Stock } \\
\text { Manufacturer/Type }\end{array}$ & Eastman Kodak/ Ektachrome \\
\hline Base Type & Triacetate \\
\hline Splices & O \\
\hline Archival Status & Archival Element \\
\hline Overall Condition & Mediocre \\
\hline
\end{tabular}

\begin{tabular}{|l|l|}
\hline Accession Number & $\mathbf{2 0 1 5 . 0 0 0 2 . 0 2 3 2}$ \\
\hline Title & {$[$ Club 57/Lenny Bruce/Scraps] } \\
\hline Gauge & Super 8mm \\
\hline Date Code & Unknown \\
\hline Colour & Colour \\
\hline Film Polarity & Reversal \\
\hline Element & Camera Original \\
\hline Sound & Magnetic Stripe \\
\hline FPS & Unknown \\
\hline Aspect Ratio & $\mathbf{1 : 3 3 : 1}$ \\
\hline Length & $\mathbf{1 5 . 0}$ ft. \\
\hline Film Wind & Unknown \\
\hline $\begin{array}{l}\text { Stock } \\
\text { Manufacturer/Type }\end{array}$ & Eastman Kodak/ Ektachrome \\
\hline Base Type & Triacetate \\
\hline Splices & 0 \\
\hline Archival Status & Archival Element \\
\hline Overall Condition & Good \\
\hline
\end{tabular}




\begin{tabular}{|l|l|}
\hline Accession Number & $\mathbf{2 0 1 5 . 0 0 0 2 . 0 2 3 3}$ \\
\hline Title & {$[$ Glenn Branca Premiere Credits] } \\
\hline Gauge & Super $8 \mathrm{~mm}$ \\
\hline Date Code & $\mathbf{1 9 8 2}$ \\
\hline Colour & Colour \\
\hline Film Polarity & Reversal \\
\hline Element & Cut Original \\
\hline Sound & Magnetic Stripe \\
\hline FPS & Unknown \\
\hline Aspect Ratio & $\mathbf{1 : 3 3 : 1}$ \\
\hline Length & $\mathbf{2 0 . 0}$ ft. \\
\hline Film Wind & B Wind \\
\hline $\begin{array}{l}\text { Stock } \\
\text { Manufacturer/Type }\end{array}$ & Eastman Kodak/ Ektachrome \\
\hline Base Type & Triacetate \\
\hline Splices & $\mathbf{1}$ \\
\hline Archival Status & Archival Element \\
\hline Overall Condition & Excellent \\
\hline
\end{tabular}

\begin{tabular}{|l|l|}
\hline Accession Number & $\mathbf{2 0 1 5 . 0 0 0 2 . 0 2 3 4}$ \\
\hline Title & {$[$ Ray Waltz across Texas] } \\
\hline Gauge & Super 8mm \\
\hline Date Code & 1981 \\
\hline Colour & Colour \\
\hline Film Polarity & Reversal \\
\hline Element & Cut Original \\
\hline Sound & Magnetic Stripe \\
\hline FPS & Unknown \\
\hline Aspect Ratio & $\mathbf{1 : 3 3 : 1}$ \\
\hline Length & $\mathbf{4 0 . 0}$ ft. \\
\hline Film Wind & B Wind \\
\hline $\begin{array}{l}\text { Stock } \\
\text { Manufacturer/Type }\end{array}$ & Eastman Kodak/ Ektachrome \\
\hline Base Type & Triacetate \\
\hline Splices & 1 \\
\hline Archival Status & Archival Element \\
\hline Overall Condition & Good \\
\hline
\end{tabular}




\begin{tabular}{|l|l|}
\hline Accession Number & $\mathbf{2 0 1 5 . 0 0 0 2 . 0 2 3 5}$ \\
\hline Title & Film \#4 \\
\hline Gauge & Super 8mm \\
\hline Date Code & Unknown \\
\hline Colour & Colour \\
\hline Film Polarity & Reversal \\
\hline Element & Camera Original \\
\hline Sound & Magnetic Stripe \\
\hline FPS & Unknown \\
\hline Aspect Ratio & $\mathbf{1 : 3 3 : 1}$ \\
\hline Length & $\mathbf{5 0 . 0}$ ft. \\
\hline Film Wind & B Wind \\
\hline $\begin{array}{l}\text { Stock } \\
\text { Manufacturer/Type }\end{array}$ & Eastman Kodak/ Ektachrome \\
\hline Base Type & Triacetate \\
\hline Splices & O \\
\hline Archival Status & Archival Element \\
\hline Overall Condition & Mediocre \\
\hline
\end{tabular}

\begin{tabular}{|l|l|}
\hline Accession Number & $\mathbf{2 0 1 5 . 0 0 0 2 . 0 2 3 6}$ \\
\hline Title & {$[$ Subway/ Sam's Opening] } \\
\hline Gauge & Super 8mm \\
\hline Date Code & Unknown \\
\hline Colour & Colour \\
\hline Film Polarity & Reversal \\
\hline Element & Cut Original \\
\hline Sound & Mag Stripe \\
\hline FPS & Unknown \\
\hline Aspect Ratio & $\mathbf{1 : 3 3 : 1}$ \\
\hline Length & $\mathbf{5 0 . 0}$ ft. \\
\hline Film Wind & B Wind \\
\hline $\begin{array}{l}\text { Stock } \\
\text { Manufacturer/Type }\end{array}$ & Eastman Kodak/ Ektachrome \\
\hline Base Type & Triacetate \\
\hline Splices & $\mathbf{1}$ \\
\hline Archival Status & Archival Element \\
\hline Overall Condition & Good \\
\hline
\end{tabular}




\begin{tabular}{|l|l|}
\hline Accession Number & $\mathbf{2 0 1 5 . 0 0 0 2 . 0 2 3 7}$ \\
\hline Title & [Untitled] \\
\hline Gauge & Super $8 \mathrm{~mm}$ \\
\hline Date Code & $\mathbf{1 9 8 2}$ \\
\hline Colour & Colour \\
\hline Film Polarity & Reversal \\
\hline Element & Camera Original \\
\hline Sound & Magnetic Stripe \\
\hline FPS & Unknown \\
\hline Aspect Ratio & $\mathbf{1 : 3 3 : 1}$ \\
\hline Length & $\mathbf{2 0 . 0}$ ft. \\
\hline Film Wind & Unknown \\
\hline $\begin{array}{l}\text { Stock } \\
\text { Manufacturer/Type }\end{array}$ & Eastman Kodak/ Ektachrome \\
\hline Base Type & Triacetate \\
\hline Splices & O \\
\hline Archival Status & Archival Element \\
\hline Overall Condition & Good \\
\hline
\end{tabular}

\begin{tabular}{|l|l|}
\hline Accession Number & 2015.0002 .0238 \\
\hline Title & [Washington- End of Symphony \#4] \\
\hline Gauge & Super 8mm \\
\hline Date Code & 1982 \\
\hline Colour & Colour \\
\hline Film Polarity & Reversal \\
\hline Element & Camera Original \\
\hline Sound & Magnetic Stripe \\
\hline FPS & Unknown \\
\hline Aspect Ratio & $1: 33: 1$ \\
\hline Length & $15.0 \mathrm{ft}$. \\
\hline Film Wind & Unknown \\
\hline $\begin{array}{l}\text { Stock } \\
\text { Manufacturer/Type }\end{array}$ & Eastman Kodak/ Ektachrome \\
\hline Base Type & Triacetate \\
\hline Splices & 0 \\
\hline Archival Status & Archival Element \\
\hline Overall Condition & Good \\
\hline
\end{tabular}




\begin{tabular}{|l|l|}
\hline Accession Number & $\mathbf{2 0 1 5 . 0 0 0 2 . 0 2 3 9}$ \\
\hline Title & {$[$ Blue Eye Footage] } \\
\hline Gauge & Super 8mm \\
\hline Date Code & Unknown \\
\hline Colour & Colour \\
\hline Film Polarity & Reversal \\
\hline Element & Camera Original \\
\hline Sound & Magnetic Stripe \\
\hline FPS & Unknown \\
\hline Aspect Ratio & $\mathbf{1 : 3 3 : 1}$ \\
\hline Length & $\mathbf{5 0 . 0} \mathrm{ft}$. \\
\hline Film Wind & Unknown \\
\hline $\begin{array}{l}\text { Stock } \\
\text { Manufacturer/Type }\end{array}$ & Unknown stock manufacturer/ Unknown stock \\
\hline Base Type & Triacetate \\
\hline Splices & $\mathbf{0}$ \\
\hline Archival Status & Archival Element \\
\hline Overall Condition & Mediocre \\
\hline
\end{tabular}

\begin{tabular}{|l|l|}
\hline Accession Number & $\mathbf{2 0 1 5 . 0 0 0 2 . 0 2 4 0}$ \\
\hline Title & {$[$ Rain- Truck Ride] } \\
\hline Gauge & Super 8mm \\
\hline Date Code & $\mathbf{1 9 8 0}$ \\
\hline Colour & Colour \\
\hline Film Polarity & Reversal \\
\hline Element & Camera Original \\
\hline Sound & Magnetic Stripe \\
\hline FPS & Unknown \\
\hline Aspect Ratio & $\mathbf{1 : 3 3 : 1}$ \\
\hline Length & $\mathbf{5 0 . 0}$ ft. \\
\hline Film Wind & B Wind \\
\hline $\begin{array}{l}\text { Stock } \\
\text { Manufacturer/Type }\end{array}$ & Eastman Kodak/ Ektachrome \\
\hline Base Type & Triacetate \\
\hline Splices & $\mathbf{0}$ \\
\hline Archival Status & Archival Element \\
\hline Overall Condition & Good \\
\hline
\end{tabular}




\begin{tabular}{|l|l|}
\hline Accession Number & $\mathbf{2 0 1 5 . 0 0 0 2 . 0 2 4 1}$ \\
\hline Title & {$[$ Belize \#1] } \\
\hline Gauge & Super 8mm \\
\hline Date Code & $\mathbf{1 9 8 2}$ \\
\hline Colour & Colour \\
\hline Film Polarity & Reversal \\
\hline Element & Cut Original \\
\hline Sound & Magnetic Stripe \\
\hline FPS & Unknown \\
\hline Aspect Ratio & $\mathbf{1 : 3 3 : 1}$ \\
\hline Length & $\mathbf{1 5 . 0}$ ft. \\
\hline Film Wind & Unknown \\
\hline $\begin{array}{l}\text { Stock } \\
\text { Manufacturer/Type }\end{array}$ & Eastman Kodak/ Ektachrome \\
\hline Base Type & Triacetate \\
\hline Splices & $\mathbf{3}$ \\
\hline Archival Status & Archival Element \\
\hline Overall Condition & Mediocre \\
\hline
\end{tabular}

\begin{tabular}{|l|l|}
\hline Accession Number & 2015.0002 .0242 \\
\hline Title & {$[$ Belize \#2] } \\
\hline Gauge & Super 8mm \\
\hline Date Code & 1982 \\
\hline Colour & Colour \\
\hline Film Polarity & Reversal \\
\hline Element & Cut Original \\
\hline Sound & Magnetic Stripe \\
\hline FPS & Unknown \\
\hline Aspect Ratio & $1: 33: 1$ \\
\hline Length & $15.0 \mathrm{ft}$. \\
\hline Film Wind & Unknown \\
\hline $\begin{array}{l}\text { Stock } \\
\text { Manufacturer/Type }\end{array}$ & Eastman Kodak/ Ektachrome \\
\hline Base Type & Triacetate \\
\hline Splices & $\mathbf{2}$ \\
\hline Archival Status & Archival Element \\
\hline Overall Condition & Mediocre \\
\hline
\end{tabular}




\begin{tabular}{|l|l|}
\hline Accession Number & $\mathbf{2 0 1 5 . 0 0 0 2 . 0 2 4 3}$ \\
\hline Title & [Untitled] \\
\hline Gauge & Super 8mm \\
\hline Date Code & $\mathbf{1 9 8 4}$ \\
\hline Colour & Colour \\
\hline Film Polarity & Reversal \\
\hline Element & Camera Original \\
\hline Sound & Magnetic Stripe \\
\hline FPS & Unknown \\
\hline Aspect Ratio & $\mathbf{1 : 3 3 : 1}$ \\
\hline Length & $\mathbf{1 5 . 0}$ ft. \\
\hline Film Wind & B Wind \\
\hline $\begin{array}{l}\text { Stock } \\
\text { Manufacturer/Type }\end{array}$ & Eastman Kodak/ Kodachrome \\
\hline Base Type & Triacetate \\
\hline Splices & O \\
\hline Archival Status & Archival Element \\
\hline Overall Condition & Mediocre \\
\hline
\end{tabular}

\begin{tabular}{|l|l|}
\hline Accession Number & $\mathbf{2 0 1 5 . 0 0 0 2 . 0 2 4 4}$ \\
\hline Title & {$[$ Untitled] } \\
\hline Gauge & Super 8mm \\
\hline Date Code & 1980 \\
\hline Colour & Colour \\
\hline Film Polarity & Reversal \\
\hline Element & Camera Original \\
\hline Sound & Magnetic Stripe \\
\hline FPS & Unknown \\
\hline Aspect Ratio & $\mathbf{1 : 3 3 : 1}$ \\
\hline Length & $\mathbf{1 5 . 0} \mathrm{ft}$. \\
\hline Film Wind & B Wind \\
\hline $\begin{array}{l}\text { Stock } \\
\text { Manufacturer/Type }\end{array}$ & Eastman Kodak/ Ektachrome \\
\hline Base Type & Triacetate \\
\hline Splices & 0 \\
\hline Archival Status & Archival Element \\
\hline Overall Condition & Good \\
\hline
\end{tabular}




\begin{tabular}{|l|l|}
\hline Accession Number & 2015.0002 .0245 \\
\hline Title & {$[$ Munich/Sunday] } \\
\hline Gauge & Super 8mm \\
\hline Date Code & 1979 \\
\hline Colour & Colour \\
\hline Film Polarity & Reversal \\
\hline Element & Camera Original \\
\hline Sound & Magnetic Stripe \\
\hline FPS & Unknown \\
\hline Aspect Ratio & $\mathbf{1 : 3 3 : 1}$ \\
\hline Length & $\mathbf{1 0 . 0} \mathrm{ft}$. \\
\hline Film Wind & Unknown \\
\hline $\begin{array}{l}\text { Stock } \\
\text { Manufacturer/Type }\end{array}$ & Eastman Kodak/ Ektachrome \\
\hline Base Type & Triacetate \\
\hline Splices & $\mathbf{0}$ \\
\hline Archival Status & Archival Element \\
\hline Overall Condition & Good \\
\hline
\end{tabular}

\begin{tabular}{|l|l|}
\hline Accession Number & $\mathbf{2 0 1 5 . 0 0 0 2 . 0 2 4 6}$ \\
\hline Title & {$[$ Untitled] } \\
\hline Gauge & Super 8mm \\
\hline Date Code & 1985 \\
\hline Colour & Colour \\
\hline Film Polarity & Reversal \\
\hline Element & Camera Original \\
\hline Sound & Magnetic Stripe \\
\hline FPS & Unknown \\
\hline Aspect Ratio & $\mathbf{1 : 3 3 : 1}$ \\
\hline Length & $\mathbf{1 0 . 0} \mathrm{ft}$. \\
\hline Film Wind & Unknown \\
\hline $\begin{array}{l}\text { Stock } \\
\text { Manufacturer/Type }\end{array}$ & Eastman Kodak/ Kodachrome \\
\hline Base Type & Triacetate \\
\hline Splices & $\mathbf{0}$ \\
\hline Archival Status & Archival Element \\
\hline Overall Condition & Good \\
\hline
\end{tabular}




\begin{tabular}{|l|l|}
\hline Accession Number & $\mathbf{2 0 1 5 . 0 0 0 2 . 0 2 4 7}$ \\
\hline Title & [Untitled] \\
\hline Gauge & Super 8mm \\
\hline Date Code & $\mathbf{1 9 8 0}$ \\
\hline Colour & Colour \\
\hline Film Polarity & Reversal \\
\hline Element & Cut Original \\
\hline Sound & Magnetic Stripe \\
\hline FPS & Unknown \\
\hline Aspect Ratio & $1: 33: 1$ \\
\hline Length & $\mathbf{1 0 . 0}$ ft. \\
\hline Film Wind & B Wind \\
\hline $\begin{array}{l}\text { Stock } \\
\text { Manufacturer/Type }\end{array}$ & Eastman Kodak/ Ektachrome \\
\hline Base Type & Triacetate \\
\hline Splices & 4 \\
\hline Archival Status & Archival Element \\
\hline Overall Condition & Mediocre \\
\hline
\end{tabular}

\begin{tabular}{|l|l|}
\hline Accession Number & $\mathbf{2 0 1 5 . 0 0 0 2 . 0 2 9 0}$ \\
\hline Title & {$[$ Untitled] } \\
\hline Gauge & Super 8mm \\
\hline Date Code & 1981 \\
\hline Colour & Colour \\
\hline Film Polarity & Reversal \\
\hline Element & Camera Original \\
\hline Sound & Magnetic Stripe \\
\hline FPS & Unknown \\
\hline Aspect Ratio & $\mathbf{1 : 3 3 : 1}$ \\
\hline Length & $\mathbf{5 . 0} \mathrm{ft.}$ \\
\hline Film Wind & Unknown \\
\hline $\begin{array}{l}\text { Stock } \\
\text { Manufacturer/Type }\end{array}$ & Eastman Kodak/ Ektachrome \\
\hline Base Type & Triacetate \\
\hline Splices & $\mathbf{0}$ \\
\hline Archival Status & Archival Element \\
\hline Overall Condition & Mediocre \\
\hline
\end{tabular}




\begin{tabular}{|l|l|}
\hline Accession Number & $\mathbf{2 0 1 5 . 0 0 0 2 . 0 2 9 0}$ \\
\hline Title & {$[$ Untitled] } \\
\hline Gauge & Super $8 \mathrm{~mm}$ \\
\hline Date Code & $\mathbf{1 9 8 5}$ \\
\hline Colour & Colour \\
\hline Film Polarity & Reversal \\
\hline Element & Camera Original \\
\hline Sound & Mag Stripe \\
\hline FPS & Unknown \\
\hline Aspect Ratio & $\mathbf{1 : 3 3 : 1}$ \\
\hline Length & $\mathbf{1 0 . 0}$ ft. \\
\hline Film Wind & Unknown \\
\hline $\begin{array}{l}\text { Stock } \\
\text { Manufacturer/Type }\end{array}$ & Eastman Kodak/ Kodachrome \\
\hline Base Type & Triacetate \\
\hline Splices & O \\
\hline Archival Status & Archival Element \\
\hline Overall Condition & Good \\
\hline
\end{tabular}

\begin{tabular}{|l|l|}
\hline Accession Number & $\mathbf{2 0 1 5 . 0 0 0 2 . 0 2 9 1}$ \\
\hline Title & {$[$ Untitled] } \\
\hline Gauge & Super 8mm \\
\hline Date Code & 1985 \\
\hline Colour & Colour \\
\hline Film Polarity & Reversal \\
\hline Element & Camera Original \\
\hline Sound & Magnetic Stripe \\
\hline FPS & Unknown \\
\hline Aspect Ratio & $\mathbf{1 : 3 3 : 1}$ \\
\hline Length & $\mathbf{1 0 . 0} \mathrm{ft.}$ \\
\hline Film Wind & Unknown \\
\hline $\begin{array}{l}\text { Stock } \\
\text { Manufacturer/Type }\end{array}$ & Eastman Kodak/ Kdachrome \\
\hline Base Type & Triacetate \\
\hline Splices & $\mathbf{0}$ \\
\hline Archival Status & Archival Element \\
\hline Overall Condition & Good \\
\hline
\end{tabular}




\begin{tabular}{|l|l|}
\hline Accession Number & $\mathbf{2 0 1 5 . 0 0 0 2 . 0 2 9 2}$ \\
\hline Title & {$[$ Untitled] } \\
\hline Gauge & Super $\mathbf{m m m}$ \\
\hline Date Code & $\mathbf{1 9 8 0}$ \\
\hline Colour & Colour \\
\hline Film Polarity & Reversal \\
\hline Element & Camera Original \\
\hline Sound & Magnetic Stripe \\
\hline FPS & Unknown \\
\hline Aspect Ratio & $\mathbf{1 : 3 3 : 1}$ \\
\hline Length & $\mathbf{3 . 0}$ ft. \\
\hline Film Wind & Unknown \\
\hline $\begin{array}{l}\text { Stock } \\
\text { Manufacturer/Type }\end{array}$ & Eastman Kodak/ Ektachrome \\
\hline Base Type & Triacetate \\
\hline Splices & O \\
\hline Archival Status & Archival Element \\
\hline Overall Condition & Good \\
\hline
\end{tabular}

\begin{tabular}{|l|l|}
\hline Accession Number & $\mathbf{2 0 1 5 . 0 0 0 2 . 0 2 9 3}$ \\
\hline Title & [Untitled] \\
\hline Gauge & Super $\mathbf{m m m}$ \\
\hline Date Code & $\mathbf{1 9 8 0}$ \\
\hline Colour & Colour \\
\hline Film Polarity & Reversal \\
\hline Element & Camera Original \\
\hline Sound & Magnetic Stripe \\
\hline FPS & Unknown \\
\hline Aspect Ratio & $\mathbf{1 : 3 3 : 1}$ \\
\hline Length & $\mathbf{3 . 0}$ ft. \\
\hline Film Wind & Unknown \\
\hline $\begin{array}{l}\text { Stock } \\
\text { Manufacturer/Type }\end{array}$ & Eastman Kodak/ Ektachrome \\
\hline Base Type & Triacetate \\
\hline Splices & O \\
\hline Archival Status & Archival Element \\
\hline Overall Condition & Good \\
\hline
\end{tabular}




\section{Bibliography}

\section{On Arleen Schloss and A's}

"Ana Mendieta: Experimental and Interactive Films: February 5, 2016 - March 26, 2016." Galerie Lelong. Accessed April 14, 2016. http://www.galerielelong.com/exhibition_pr/3377.

De La Haba, Gregory. "December 2012: In Conversation with Arlene Schloss." Whitehot Magazine. Accessed November 15, 2015. http://whitehotmagazine.com/articles/inconversation-with-arlene-schloss/2682.

Erickson, Dave. "An Exhibit with Real Snap- By Any Stretch of Imagination." University of Rochester Currents, 1975.

How She See's It by Her. Directed by Arleen Schloss. Arleen Schloss, 1981. Super 8mm Film, 1981.

McKee, Sandra. "A's For Performance" Soho Weekly, March 4, 1981.

Miller, Eric. "Live Video as Performance on New York City's Lower East Side in the 1980s," In Captured: A Film/Video History of the Lower East Side, edited by Paul Bartlett, Urania Mylonas, and Clayton Patterson, 249-254. New York, NY: Seven Stories Press, 2005.

New Museum. "Arleen Schloss: An Evening of Super 8 Film and Hi8 Video." New Museum Digital Archive. Accessed October 16, 2015. http://archive.newmuseum.org/index.php/Detail/Occurrence/Show/occurrence_id/1659.

"Interview with Arleen Schloss." YouTube video, 02:44. Posted by New Museum. December 21, 2012. https://www.youtube.com/watch?v=DXHMIUJv6N4.

Palmer, Robert. "Music (?): Kitchen Sink.” New York Times, October 13, 1977.

Patteron, Clayton. "Arleen Schloss Interview." In Captured: A Film/Video History of the Lower East Side, edited by Paul Bartlett, Urania Mylonas, and Clayton Patterson, 193-206. New York, NY: Seven Stories Press, 2005.

Peron, Wendy. "Dumb Art: Beautiful but Not Too Bright," originally published in Village Voice, January 2, 1978. In Through the Eyes of a Dancer: Selected Writings, 77-81.

Middletown, CT: Wesleyan University Press, 2013.

Swan, Ethan. "Arleen Schloss," In Bowery Artist Tribute Vol.2, edited by Ethan Swan, 15-16. New York, NY: New Museum, 2010.

"Universe of A / Arleen Schloss." YouTube video, 01:34. Posted by Arleen Schloss. December 6, 2008. https://www.youtube.com/watch?v=cd-msSq888A. 
"Wednesdays At A's Teaser." YouTube video, 07:55. Posted by Stuart Ginsberg. April 19, 2010. https://www.youtube.com/watch?v=FcVs-3QHgjE.

Weichselbaum, Simone. "For Struggling Artists, It's a Cash to Crash at SoHo Pad." New York Daily News, October 4, 2009. Accessed March 12, 2016.

http://www.nydailynews.com/life-style/real-estate/struggling-artists-cash-crash-soho-padarticle-1.406511.

\section{On The Downtown New York Art Scene}

Ault, Julie, ed. Alternative Art New York: 1965-1985. Minneapolis, MN: University of Minnesota Press, 2002.

Hawkins, Joan, ed. Downtown Film and TV Culture 1975-2001. Chicago, IL: University of Chicago Press, 2015.

J. Taylor, Marvin, ed. The Downtown Book. Princeton, NJ: Princeton University Press, 2006.

Moore, Alan and Jim Cromwell. "Local History: The Art of Battle from Bohemia in New York." In Alternative Art New York, 1965-1985, edited by Julie Ault, 321-365. Minneapolis, MN: University of Minnesota Press, 2002.

New Museum. "Come Closer: Art Around the Bowery, 1969-1989.” New Museum Digital Archive. Accessed October 16, 2015.

http://archive.newmuseum.org/index.php/Detail/Occurrence/Show/occurrence_id/1676

\section{On Film Preservation, Handling and Restoration}

Ascher, Steven and Edward Pincus. The Filmmaker's Handbook, 4th ed. London, England: Penguin Group, 2012.

Association of Cinema and Video Laboratories. Handbook: Recommend Procedures for Motion Picture and Video Laboratory Services. Rev. ed. Bethesda, MD: Association of Cinema and Video Laboratories, 1982.

Case, Dominic. Film Technology in Post Production. 2nd ed. Oxford, England: Focal Press, 2001.

Eastman Kodak Company. The Book of Film Care. Rochester, NY: Eastman Kodak Company, 1992.

Gracy, Karen F. "Documenting the Process of Film Preservation.” The Moving Image, no. 1 (Spring 2003): 1-41. 
Harvey, Ross and Martha R. Mahard. The Preservation Management Handbook: A 21st- Century Guide for Libraries, Archives and Museums. New York, NY: Rowman \& Littlefield, 2014.

The National Film Preservation Foundation. The Film Preservation Guide. San Francisco, CA: The National Film Preservation Foundation, 2004.

Volkmann, Herbert. A Report of the Preservation Committee of the International Federation of Film Archives. London, England: National Film Archive, 1965.

\section{On Small Gauge Filmmaking, Archiving and Amateur Cinema}

Dick, Terrence. "Koda-Crime! A Eulogy to Super 8 Kodachrome." This Magazine, November/December, 2005.

Gampat, Chris. "Remembrance: Four Years Since the Death of Kodak Ektachrome" The Phoblographer. Last modified March 1, 2016. Accessed March 5, 2016. http://www.thephoblographer.com/2016/01/03/remembrance-four-year-since-the-deathof-kodak-ektachrome/\#.V0RbRsfSdo4.

Hoberman, J. "Explorations: Low Tech, High Art." American Film (Archive: 1975-1992) 5, no. 6 (Apr 01, 1980): 13-14, 66.

Hoberman, J. "The Super-80s." Film Comment 17, no. 3 (May 1981): 39-43, 80.

Horak, Jan-Christopher. "Out of the Attic: Archiving Amateur Film.” Journal of Film Preservation, no. 56 (June 1998): 50-53.

Kattelle, Alan. Home Movies: A History of the American Industry, 1897-1979. Nashua, NH: Transition Publishing, 2000.

Kilchesty, Albert. Big As Life: An American History of 8mm Films. New York, NY: Museum of Modern Art; and San Francisco, CA: San Francisco Cinematheque, 1998.

Rascaroli, Laura, Gwenda Young, and Barry Monahan, eds. Amateur Filmmaking: The Home Movie, The Archive, The Web. New York, NY: Bloomsbury Academic, 2014.

\section{On Super 8mm: Practical Guides}

Gunter, Jonathan F. Super 8: The Modest Medium. Paris, France: UNESCO, 1976.

Lipton, Lenny. The Super 8 Book. San Francisco, CA: Straight Arrow Books, 1975. 
Kodak Motion Picture Film. "Super 8mm Products." Accessed February 12, 2016. http://motion.kodak.com/motion/products/production/spotlight_on_super_8/super_8mm products/index.htm.

OnSuper8. "A Quick Guide.” Last modified 2016. Accessed January 12, 2016. http://onsuper8.cambridge-super8.org/faqs/a-quick-guide/.

OnSuper8. "Film Overview." Last modified 2016. Accessed January 12, 2016. http://onsuper8.cambridge-super8.org/film-stock-a-to-z/film-overview/.

Treadway, Toni. "Home Movies: A Basic Primer on Care, Handling, Storage.” Little Film. Accessed March 12, 2016. http://www.littlefilm.org.

\section{Other}

Anthology Film Archives. "About/History." Accessed September 17, 2015. http://anthologyfilmarchives.org/about/history.

CollectiveAccess. "About CollectiveAccess.” Accessed January 14, 2016. http://www.collectiveaccess.org/about.

Kase, Carlos. "On the Importance of Anthology Film Archives: A Historical Overview and Endorsement," In Captured: A Film/Video History of the Lower East Side, edited by Paul Bartlett, Urania Mylonas, and Clayton Patterson, 85-100. New York, NY: Seven Stories Press, 2005.

Vanilla Video. "The History of Frame Rates: Why Speeds Vary." Last modified December 16, 2012. Accessed April 4, 2016. https://vanillavideo.com/blog/2012/history-frame-rateswhy-speeds-vary. 